Sheffield

Hallam

University
Centre for

Regional Economic

and Social Research

\title{
Labour Market \\ Participation, Skills, and \\ Employment in Rotherham
}

February 2019 


\section{Labour Market Participation, Skills, and Employment in Rotherham}

Authors:

Christina Beatty

Tony Gore

David Leather

February 2019

DOI: 10.7190/cresr.2019.3478393864 


\section{Acknowledgements}

The research team would like to acknowledge the support of Rotherham Council in commissioning this study. Special thanks go to Simeon Leach for being so patient during the extended period required to secure permission to access the Secure Access Annual Population Survey from the UK Data Service.

We would also like to thank the UK Data Service Support Help Desk, especially James Scott and Deborah White, in their work in verifying all APS data used in this report is non-disclosive. 


\section{Contents}

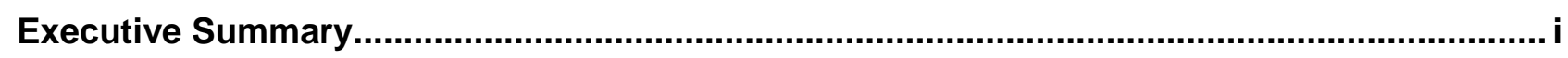

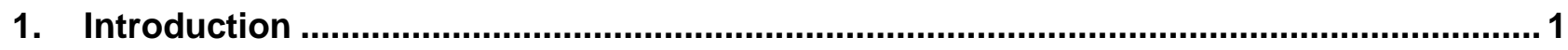

2. The size of the workforce in Rotherham ..................................................................

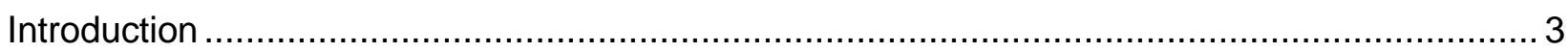

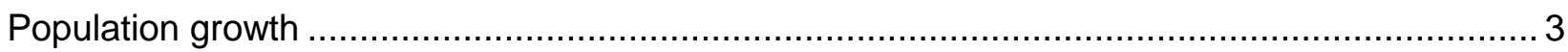

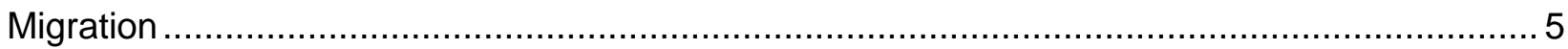

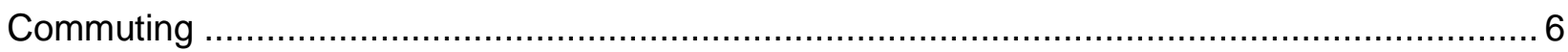

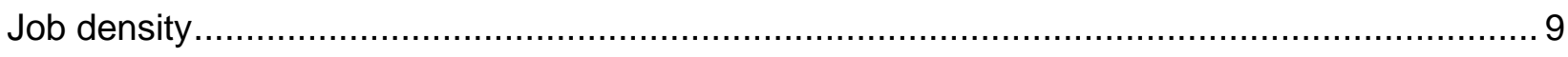

3. Labour market characteristics of the workforce in Rotherham......................................11

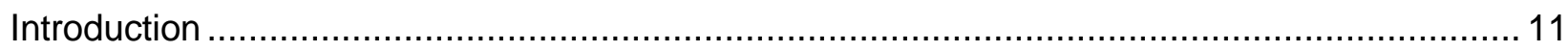

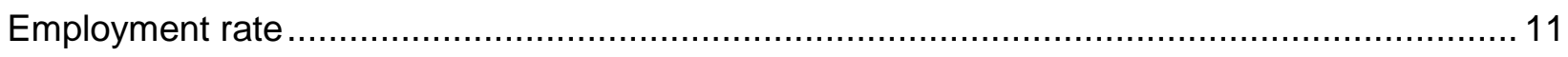

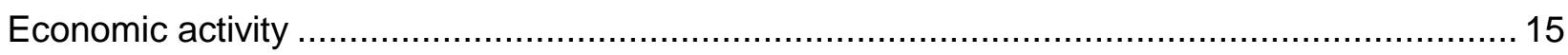

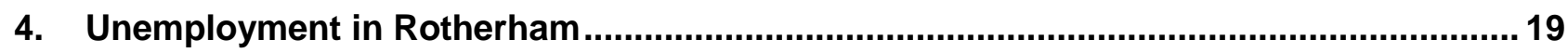

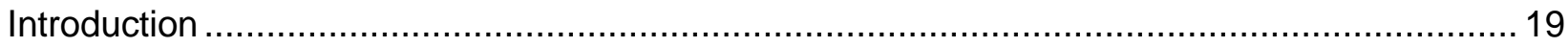

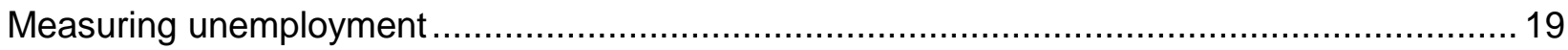

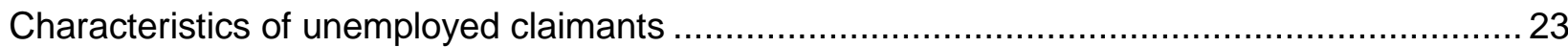

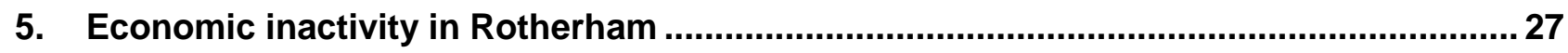

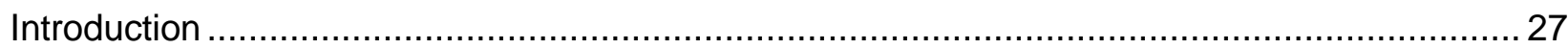

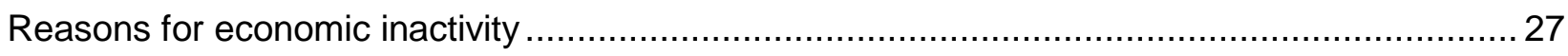

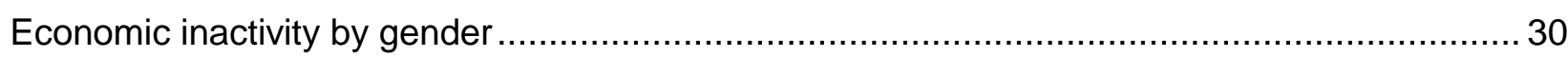

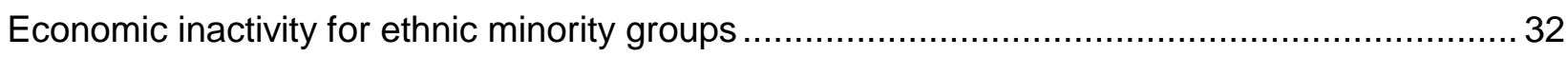

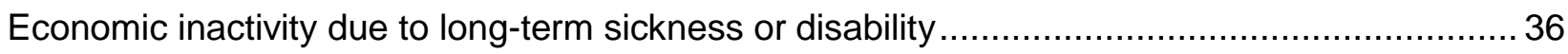

Distribution of disadvantaged groups in Rotherham ……...................................................... 38

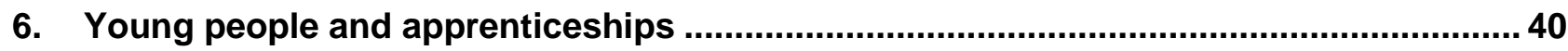

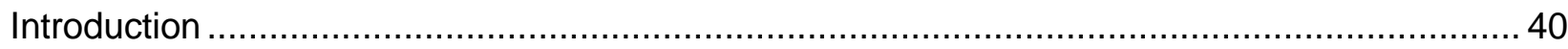

Not in education, employment or training (NEETS) ………........................................... 41

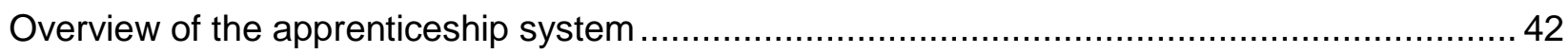




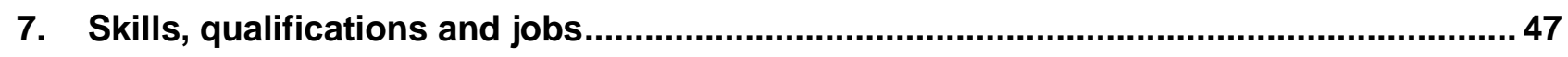

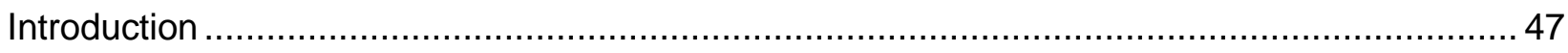

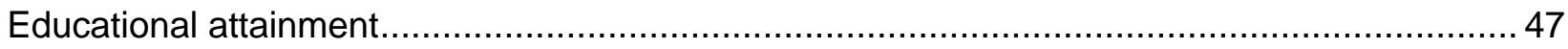

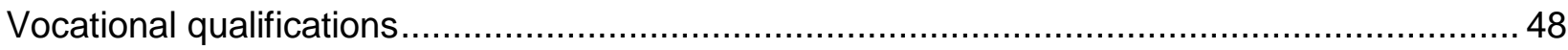

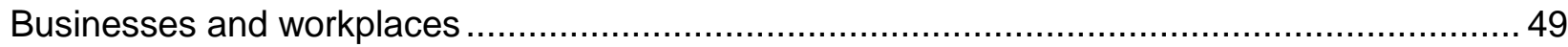

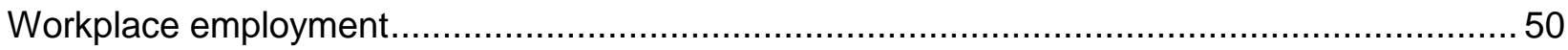

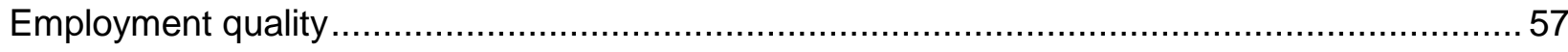

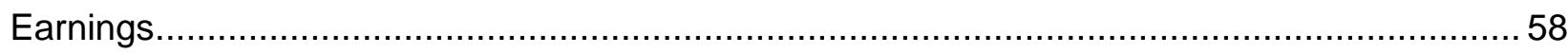

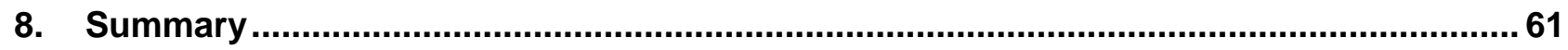

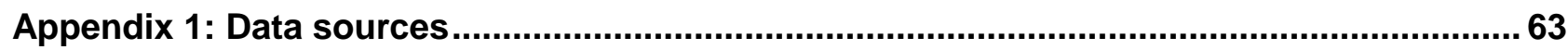




\section{Contents: Tables and Figures}

Table 2.1: Growth in the working age population in Rotherham, $2010-2017 \ldots \ldots \ldots \ldots \ldots \ldots \ldots \ldots \ldots . \ldots \ldots$

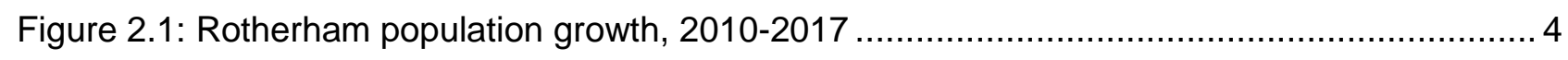

Table 2.2: Migration inflows and outflows to and from Rotherham, 2010-2017 ........................5

Table 2.3: Commuting in-flows to and out-flows from Rotherham, 16-64 year olds in employment,

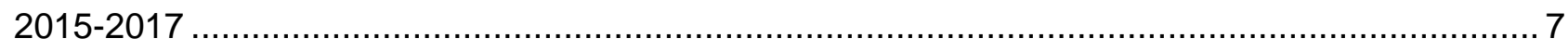

Table 2.4: Commuting in-flows and out-flows for districts within Sheffield City Region, 16-64 year

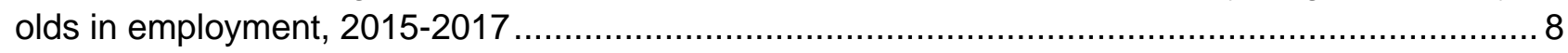

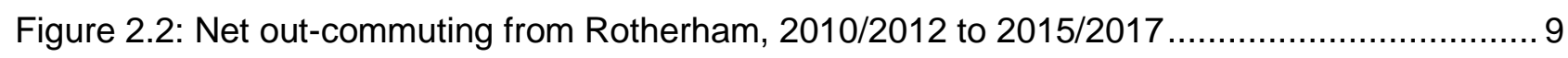

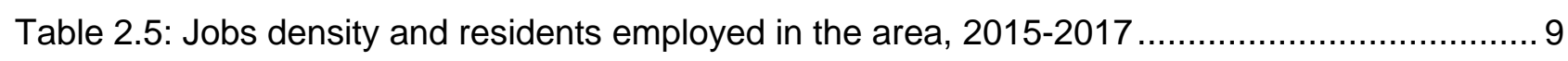

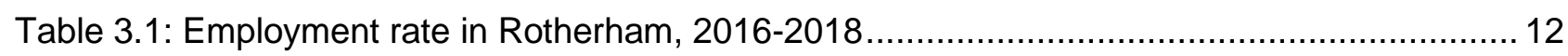

Table 3.2: Employment rate in Rotherham, 2010-2012 to 2016-2018 .................................... 12

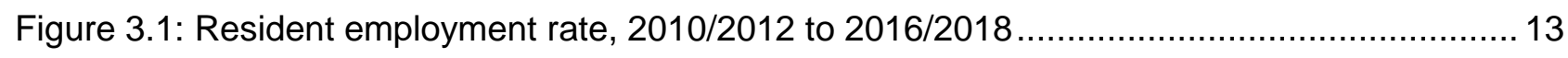

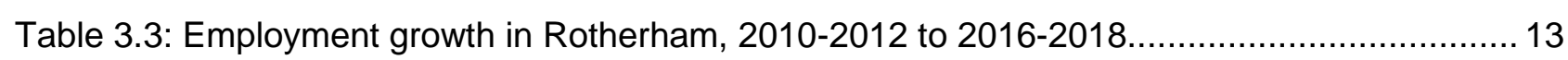

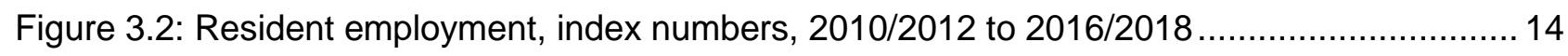

Table 3.4: Growth in the number of workers with a workplace in Rotherham, 2010-2012 to 2016-

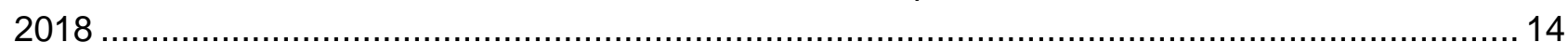

Figure 3.3: Growth in the number of workers with a workplace in Rotherham, index numbers,

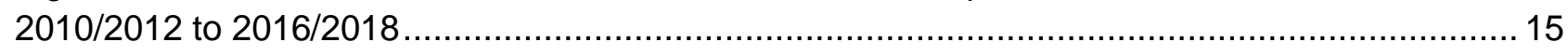

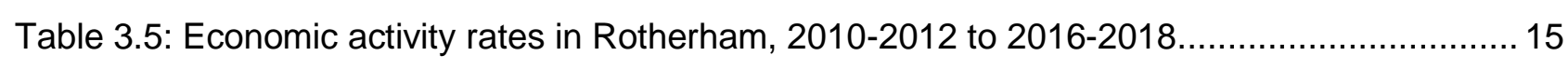

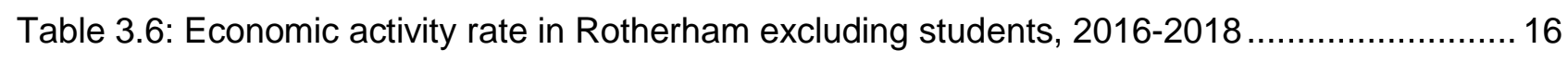

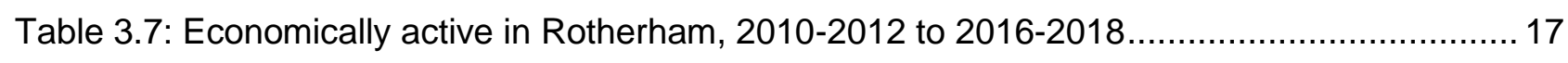

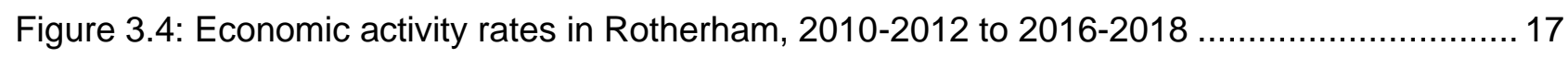

Figure 3.5: Smoothed time series of economic activity rates in Rotherham, 2010-2012 to 2016-

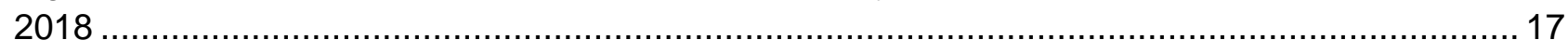

Figure 4.1: Alternative unemployment rates in Rotherham, 2013-2018................................ 21 
Table 4.1: Alternative unemployment measures, 2013-2018

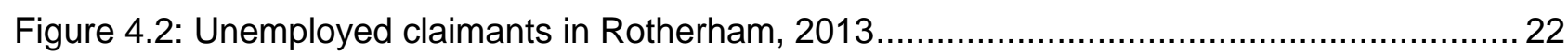

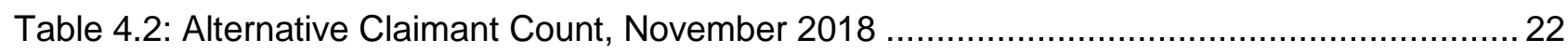

Table 5.1: Reasons for economic inactivity in Rotherham, 16-64 year olds, 2015-2017.............28

Table 5.2: Economic inactivity in Rotherham by age, 16-64 year olds, $2015-2017 \ldots \ldots \ldots \ldots \ldots \ldots \ldots . . . . . . .29$

Table 5.3: Economic inactivity Rotherham residents by reason, 16-64 year olds, 2015-2017 ....... 31

Table 5.4: Reasons for economic inactivity, Rotherham, economically inactive 16-64 year olds, 2015-2017 32

Table 5.5: Economic inactivity and employment rates by ethnic groups, England, 16-64 year olds, 2015-2017 33

Table 5.6: Economic inactivity and employment rates by ethnic groups, Rotherham, 16-64 year olds, 2015-2017. 34

Table 5.7: Economically inactive who want a job, Rotherham, 16-64 year olds, 2015-2017......... 35

Figure 5.1: Incapacity benefits claimant rate, 16-64 year olds, Rotherham, 2010-2018 36

Table 5.8: Skills and qualifications of JSA claimants aged 18-64, Great Britain, July - September 2015

Table 5.9: English as a second language, ESA claimants aged 18-64, Great Britain, July September 2015. 38

Figure 5.2: Index of Multiple Deprivation 2015, Rotherham .............................................. 39

Table 6.1:16-17 year olds in education and training in Rotherham, March 2018 ..................... 41

Table 6.2:16-17 year olds in education and training in Rotherham by ethnicity, March $2018 \ldots \ldots . .42$

Table 6.3:16-17 year olds in education and training in Rotherham by ethnicity, March 2018 ....... 42

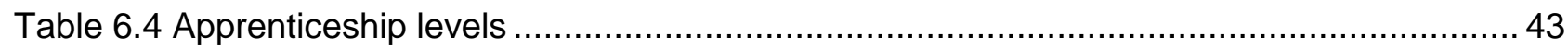

Table 6.5: Apprenticeships in Rotherham by level, 2014/2015 to 2017/2018 ........................... 44

Table 6.6: Apprenticeships in Rotherham by age, $2014 / 2015$ to $2017 / 2018$........................... 45

Table 6.7: Apprenticeships in Rotherham by sector, $2014 / 2015$ to $2017 / 2018 \ldots \ldots \ldots \ldots \ldots \ldots \ldots \ldots . \ldots . \ldots \ldots$

Table 6.8: Change in Apprenticeships starts in Rotherham by main sectors, 2015/2016 to

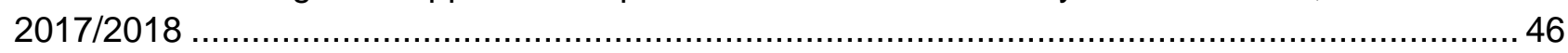

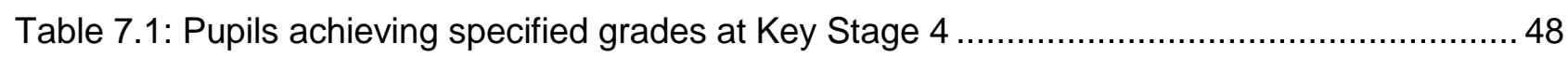

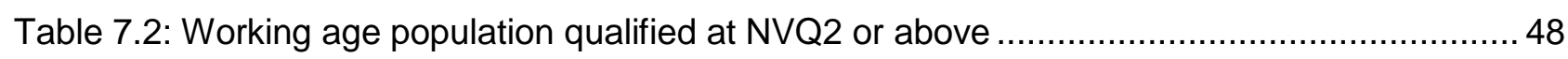


Table 7.3: Workplaces

Table 7.4: Sectoral breakdown of local workplaces in Rotherham 50

Table 7.5: Sectoral breakdown of workplace employment, Rotherham, 2010-2017 50

Table 7.6: Recent employment change by sector, Rotherham, 2015-2017 51

Figure 7.1: Workplace Employment Change by Ward: All Sectors, 2015-2017 52

Figure 7.2: Workplace Employment Change by Ward: Manufacturing, 2015-2017 53

Figure 7.3: Workplace Employment Change by Ward: Distribution and Logistics, 2015-2017....... 54

Figure 7.4: Workplace Employment Change by Ward: Private Sector Services, 2015-2017 ........ 55

Fig 7.5: Workplace Employment Change by Ward: Public Sector Services, 2015-2017 56

Table 7.7: Resident employment in higher level occupations 57

Table 7.8: Workplace employment in 'low pay' sectors 58

Table 7.9: Median gross weekly earnings for full-time workers 58

Table 7.10: Gross weekly earnings for full-time workers in lowest income group 59

Table 7.11: Ratio between median and lowest paid gross weekly earnings 59 


\section{Executive Summary}

Skills and employment are central to the Rotherham Plan for economic growth. The aim is to support people to obtain work, to stay in work and to progress at work. A greater understanding is therefore needed of the skills, qualifications, barriers to work and nature of economic activity amongst the local workforce. This research provides a comprehensive profile of working age residents in Rotherham in the context of the local labour market. The findings indicate that it is important to get beyond a profile of the workforce as a whole because substantial variations in characteristics exist between and within different sub-groups in the population.

\section{The size of the workforce}

- There are just over 160,000 people of working age in Rotherham. The size of the potential workforce contracted slightly between 2010 and 2017 (by one per cent) compared to growth of two per cent nationally.

- The number of 16-24 year olds fell by almost three times the rate seen in Britain between 2010 and 2017 (eight per cent decrease compared to three per cent).

- There are substantial flows of workers into and out of Rotherham on a daily basis; 34,800 and 48,500 respectively which results in net-out commuting of 13,700 people.

- 57 per cent of all residents in employment live and work in the district; 35 per cent of jobs in Rotherham are filled by people from outside the district; 94 per cent of jobs in Rotherham are taken by workers from within the Combined Authority.

\section{Economic activity}

- Just over three quarters of all working age residents in Rotherham are actively participating in the labour market; the economic activity rate has increased by 1.6 percentage points since 2010-2012 to 76.3 per cent in 2016-2018.

- The rise in the economic activity rate is a product of a shrinking denominator (the working age population) rather than a substantive increase in the numerator (more economically active people).

- There is a higher economic activity rate for $16-24$ years olds in Rotherham (66 per cent) than in Sheffield City Region (62 per cent) and Great Britain (61 per cent).

\section{Employment}

- $\quad$ The local employment rate is 71.8 per cent which lagged behind the national rate of 74.4 per cent in 2016-2018.

- The employment rate in Rotherham improved at a faster rate than nationally between 20102012 and 2016-2018 which narrowed the gap between the two.

- $\quad$ Between 2010-2012 and 2016-2018, employment growth amongst Rotherham residents (5.5 per cent) lagged behind the growth seen in the Combined Authority ( 9.3 per cent), in Sheffield City Region (7.8 per cent) and nationally (7.9 per cent). 
- The employment rate for Pakistani/Bangladeshi women in Rotherham is very similar to that seen nationally; 34 per cent and 36 per cent respectively.

- The employment rate for white women in Rotherham is 67 per cent compared to 72 per cent for England.

\section{Unemployment}

- At September 2018, the ILO unemployment rate for Rotherham (those who are looking for and available for work) stood at 3.9 per cent of the working age population; only slightly higher than the national rate of 3.4 per cent.

- Unemployment in Rotherham (on any measure) halved between 2013 and 2018 a more rapid decline than seen nationally.

- At September 2018, the Claimant Count (those eligible for unemployment related benefits) stood at 2.6 per cent of the working age population; this compares with a national rate of 2.2 per cent.

- Claimants of unemployment related benefits in England are more likely than the employed to have no formal qualifications: one in five compared with one in twenty; they are also far less likely to have a degree or qualification gained from higher education than those in employment: 17 per cent compared to 43 per cent.

- National data indicates that eight per cent of JSA claimants have not used the internet in the past month, rising to 10 per cent of the long-term unemployed and 14 per cent of claimants aged over 50.

\section{Economic inactivity}

- Economic inactivity rates amongst working age people in Rotherham are only slightly higher than the national average in 2015-2017 (24 per cent and 22 per cent respectively).

- In Rotherham, looking after a home or family (6 per cent of working age people) or being longterm sick or disabled ( 6 per cent) are the two most common reasons for being economically inactive - simlar to the pattern seen in England (5 per cent for each).

- Treble the national rate of 16-24 year olds are long term-sick or disabled in Rotherham; 6 per cent compared to 2 per cent.

- Double the national rate of 16-24 year olds in Rotherham stay at home to look after a home or a family; 6 per cent compared to 3 per cent.

- A higher proportion of 50-64 year olds in Rotherham are economically inactive compared to nationally; 31 per cent compared to 27 per cent.

- Economic inactivity rates amongst the Pakistani/Bangladeshi population in England are almost double those for whites (39 per cent compared to 20 per cent) and a similar ratio is seen in Rotherham (45 per cent compared to 23 per cent).

- Economic inactivity rates for white men in Rotherham is similar to that seen nationally (17 per cent versus 16 per cent), but more notable differences exist amongst Pakistani/Bangladeshi men; 31 per cent in Rotherham compared to 22 per cent in England.

- 62 per cent of Pakistani/Bangladeshi women in Rotherham are economically inactive, only four percentage points higher than for England (58 per cent).

- The economic inactivity rate of white women in Rotherham is also four percentage points higher than in England; 29 per cent and 25 per cent respectively. 


\section{Long term sickness or disability}

- In May 2018, 12,750 working age people in Rotherham were claiming incapacity related benefits (7.9 per cent of working age population) compared to 5.5 per cent in Britain; this is substantially higher than the local unemployment rate.

- Employment and Support Allowance claimants in Britain are more likely to have poor skills or qualifications than other groups; over a quarter have no formal qualifications compared to one in five JSA claimants and one in twenty of those in employment.

- $\quad$ ESA claimants who are closer to the labour market (either those looking for or available for work or with a duration under one year) are more similar to the profile seen amongst JSA claimants.

- 14 per cent of ESA claimants have never used the internet compared to five per cent of JSA claimants.

- Only 6 per cent of ESA claimants in England have English as a second language (ESOL) but 27 per cent of these have had language difficulties in education (27 per cent) and in finding or keeping a job (28 per cent); this compares to those in employment with ESOL (10 per cent) where the comparable figures are eight per cent and 14 per cent respectively.

\section{Qualifications and skills}

- 59 per cent of pupils in Rotherham achieved $A^{*}-C$ in English and Mathematics at GCSE or equivalent in 2016/2017 which is on par with the national average of 59.1 per cent.

- $\quad$ This was a decrease of 1.5 percentage points from the position in 2013/2014 and contrary to an improvement of 3.6 percentage points nationally and 5.7 percentage points in the Sheffield City Region.

- $\quad 65.6$ per cent of working age residents in Rotherham are qualified at NVQ2 or above (20152017); this lags behind the other districts in the Combined Authority and the 71 per cent seen for Sheffield City Region as a whole.

- $\quad$ The percentage of working age people with an NVQ2 increased by 3.4 percentage points between 2010-2012 and 2015-2017; this was far lower than the improvement seen in the Combined Authority as a whole (9.4 percentage points).

\section{Apprenticeships}

- $\quad 92.3$ per cent of 16 and 17 year olds in Rotherham in 2018 were in education or training.

- $\quad 77.4$ per cent in full-time education or training compared to 83.8 per cent nationally.

- $\quad 7.7$ per cent in Apprenticeships compared to 5.9 per cent per cent nationally.

- $\quad 4.7$ per cent in work based learning compared to 1.2 per cent per cent nationally.

- 2.5 per cent in employment combined with study compared to 0.7 per cent nationally.

- The number of Apprenticeships began to fall after the Apprenticeship Levy was introduced in May 2017; there were 2,010 Apprenticeships in Rotherham in 2017/2018 compared to 3,290 in 2015/2016.

- $\quad$ This represents a decrease of 39 per cent between over the period compared to a 26 per cent decrease in England.

- The decline in Apprenticeships was greatest for those aged over 25 year old; the number of starts in Rotherham fell by 43 per cent between 2015/16 and 2017/18 compared to 31 per cent nationally. 
- In 2017/18, 84.1 per cent of all Apprenticeship starts in Rotherham were in Health, Public Services and Care; Business, Administration and Law; Retail \& Commercial Enterprise; and Engineering and Manufacturing Technologies; this is similar to the national pattern (83.2 per cent).

\section{Jobs}

- The number of workplaces in Rotherham increased by nearly a quarter between 2010-2012 and 2015-2017 (23.4 per cent); this was faster than the growth seen in Britain (19.3 per cent) or Sheffield City Region (20.2 per cent) over the same period.

- In 2015-2017, there were 30 workplaces per 1,000 population which is lower than seen in Sheffield City Region (34 per 1,000) or nationally (45 per 1,000).

- The growth in workplaces in Rotherham over the period was greatest in business services (47.8 per cent), construction (35 per cent), hospitality and catering (28.2 per cent) and distribution and logistics (18.9 per cent).

- A third of all jobs in Rotherham are in public services, a further one in five are in business services and one in five are in distribution and logistics.

- $\quad$ The number of jobs in Rotherham between 2015 and 2017 was relatively static (0.4 per cent decline) but there was a wide variation across sectors; fastest growth was in primary activities (15.8 per cent), the construction sector (14.3 per cent), and employment in public services declined by 8.7 per cent.

- $\quad 34.3$ per cent of residents in Rotherham are employed in higher level occupations compared to 38.2 per cent in Sheffield City Region and 45.2 per cent nationally.

- The number of Rotherham residents employed in higher level jobs increased by 13 per cent between 2010-2012 and 2016-2018 compared to a 15 per cent growth nationally.

- $\quad$ Around a third of residents are employed in 'low pay' sectors; employment in these sectors increased by almost 10 per cent between 2010-2012 and 2015-2017 in line with growth observed in the Combined Authority and the national picture.

\section{Earnings}

- In 2016-2018, the median gross earnings for full-time workers in Rotherham was $£ 396$ a week 11.5 per cent higher than in 2010-2012; this compares well with 8.7 per cent growth in Sheffield City Region and 11.1 per cent nationally.

- However, median gross weekly earnings in Rotherham were still £54 a week lower than the national average.

- The gross full-time weekly earnings for those in the bottom 20 per cent of the wages distribution was £214 a week compared with the average in Sheffield City Region of $£ 217$ and in Britain £238.

- $\quad$ The lower quintile of earnings in Rotherham has risen faster than median earnings with 13.8 per cent growth between 2010-2012 and 2016-2018; this compares with 14.4 per cent growth in Britain. 


\section{Introduction}

Skills and employment is one of the key themes of the Rotherham Plan for economic growth. The aim is to help people to obtain employment, stay in work and progress at work by providing support that meets residents' needs. This piece of research has been commissioned by Rotherham Borough Council to provide a comprehensive profile of the Rotherham workforce in the context of the local labour market. The research aims to provide a greater understanding of the skills, qualifications and nature of economic activity amongst the workforce. Barriers to participation in the workforce are identified in order to highlight where employment and skills support can most efficiently be targeted to support local employers as well as the local workforce.

The report highlights that it is important it is to get beyond the characteristics of the workforce as a whole and instead to identify how these vary substantially by particular subgroups in the population. This may include differences in labour market participation, aspirations to work, skills and qualifications. Subsequently, this may require different employment support solutions which are tailored to meet the needs of particular sub-groups of the potential workforce rather than delivering generic provision.

The analysis provided here, therefore, benchmarks the characteristics of sub-groups of the working age population against similar groups in the wider city region and nationally. This enables us to understand if any differences identified in labour market performance are a consequence of the standard structural make-up of the workforce or if there are particular issues specific to Rotherham that need to be addressed. The analysis considers some key differences within the working age population by variables such as age, sex and ethnicity.

Employment and skills cannot be considered purely as a supply side issue. The demand side of the equation including growth in employment opportunities in the local authority area and the wider city region, as well as the skills needs of local employers or particular industrial sectors need to be considered. Ensuring that local training and education opportunities can support local employers' needs is crucial. Enabling the local working age population to access employment support or training opportunities will also enhance their employment prospects. More joined-up working amongst providers, employers and the workforce has the potential to help the borough to achieve its ambition to create a more highly skilled workforce which has access to good, well-paid and sustainable work.

The project consists of two strands of research which examine evidence on both the supply and demand sides of the local labour market. The first strand includes an analysis of a wide range of secondary and administrative data sources to provide a comprehensive overview of 
the local labour market and workforce. The datasets examined are available from the following sources:

- $\quad$ NOMIS - the ONS official labour market statistics;

- $\quad$ Stat-Xplore - DWP Benefits Data;

- UK Data Service - secure access to pooled local authority level data from the Annual Population Survey.

A description of each of the individual datasets used is provided in Appendix A.

The second strand of research involved in-depth interviews with 20 stakeholders in Rotherham. The consultation exercise was conducted between June and August 2018. Representatives of public, private and voluntary sector organisations were interviewed faceto-face or by telephone, with each discussion lasting between 30 minutes and an hour. The discussions were wide-ranging and varied according to the knowledge and expertise of each respondent, but overall the consultation focused on the following matters:

- General economic situation in the local area;

- Skills gaps and recruitment difficulties;

- Vocational education and training;

- Apprenticeships;

- Economic inclusion of disadvantaged groups;

- $\quad$ Specific barriers facing marginalised groups;

- Existing provision to address barriers and issues;

- $\quad$ Networking between policy-makers, funders, providers and employers;

- $\quad$ Suggestions for new initiatives (or how to make the current system work better).

The findings from the two strands of research are interwoven throughout the report to provide key insights on both supply and demand side perspectives on each of the issues examined. 


\section{The size of the workforce in Rotherham}

\section{Introduction}

Britain's labour market has gone through substantial changes since the 1980s. This includes a decline in manufacturing and a shift towards service sector employment, increasing participation in the workforce amongst women, a move towards more flexible labour markets and a growth in non-standard employment. In much of older industrial Britain, such as Rotherham, this has had a major impact on the structure of the local market, the types of job opportunities available, average levels of pay and skills needs of local employers.

In more recent times, the British labour market has had to adjust to the aftermath of a major global recession in 2008-2009 which was followed by a period of stagnation and low economic growth. Even though the national economy has recovered, with Britain now boasting record numbers of people in work and employment rates at an all-time high, there still remain significant issues around long-term wage stagnation and the uneven nature of growth across the country.

For Rotherham, this requires a multifaceted and strategic approach to ensuring that the local workforce and employers are in the best position to maximise their economic and productivity growth potential. The first stage of this strategy is to understand the characteristics, training and skill needs of both the potential workforce ${ }^{1}$ and local employers.

\section{Population growth}

Population dynamics contribute to the size of the workforce in any given area. These can be due to fluctuations in the birth rate in previous years as well as increases in life expectancy as more people live for longer beyond retirement age. Net internal and international migration trends also contribute to the size of the workforce.

Some of the population dynamics in Rotherham between 2010 and 2017 echo those seen nationally (Table 2.1). However, the scale of change locally is greater for some age groups or contrary to national trends for others. Overall, Rotherham experienced less than half the

\footnotetext{
${ }^{1}$ The workforce is defined as the working age population (16-64 year olds); includes those currently economically active and currently participating in the workforce (the employed and unemployed) as well as the economically inactive that might potentially be drawn into economic activity.
} 
rate of population growth than seen nationally. Growth was primarily due to a substantial increase in the number of people of retirement age (15.4 per cent) as well as growth in the potential workforce aged 50-64 years old (5.6 per cent) (Figure 2.1). This trend towards an increasingly ageing population is also seen nationally.

Table 2.1: Growth in the working age population in Rotherham, 2010-2017

\begin{tabular}{|c|c|c|c|c|}
\hline & \multicolumn{2}{|c|}{ Rotherham Population 2017} & \multicolumn{2}{|c|}{$\begin{array}{l}\text { Percentage change in } \\
\text { population, 2010-2017 }\end{array}$} \\
\hline & Number & $\begin{array}{l}\text { Percentage of } \\
\text { total population }\end{array}$ & Rotherham & GB \\
\hline Aged 0 to 15 & 50,900 & 19.3 & 3.2 & 6.0 \\
\hline Aged 16 to 24 & 26,100 & 9.9 & -8.0 & -2.9 \\
\hline Aged 25 to 49 & 82,800 & 31.4 & -3.0 & 0.2 \\
\hline Aged 50 to 64 & 52,500 & 19.9 & 5.6 & 9.2 \\
\hline Aged 65+ & 51,000 & 19.4 & 15.4 & 16.8 \\
\hline Aged 16 to 64 & 161,400 & 61.3 & -1.1 & 2.2 \\
\hline All Ages & 263,400 & 100.0 & 2.5 & 5.3 \\
\hline
\end{tabular}

Source: ONS Mid-year population estimates

However, contrary to national trends between 2010 and 2017, Rotherham's working age population contracted by 1.1 per cent compared to a 2.2 per cent growth nationally. In part, this was due to the decline in the number of 16-24 year olds which contracted by almost three times the rate seen in Britain (8 per cent decline compared to 2.9 per cent in GB). The number of 25-49 year olds also declined slightly in Rotherham over the period (by 3 per cent) compared to a stable picture nationally. The contraction of the working age population in Rotherham means that it now accounts for 61.3 per cent the overall population down by 2.7 percentage points since 2010 .

Figure 2.1: Rotherham population growth, 2010-2017

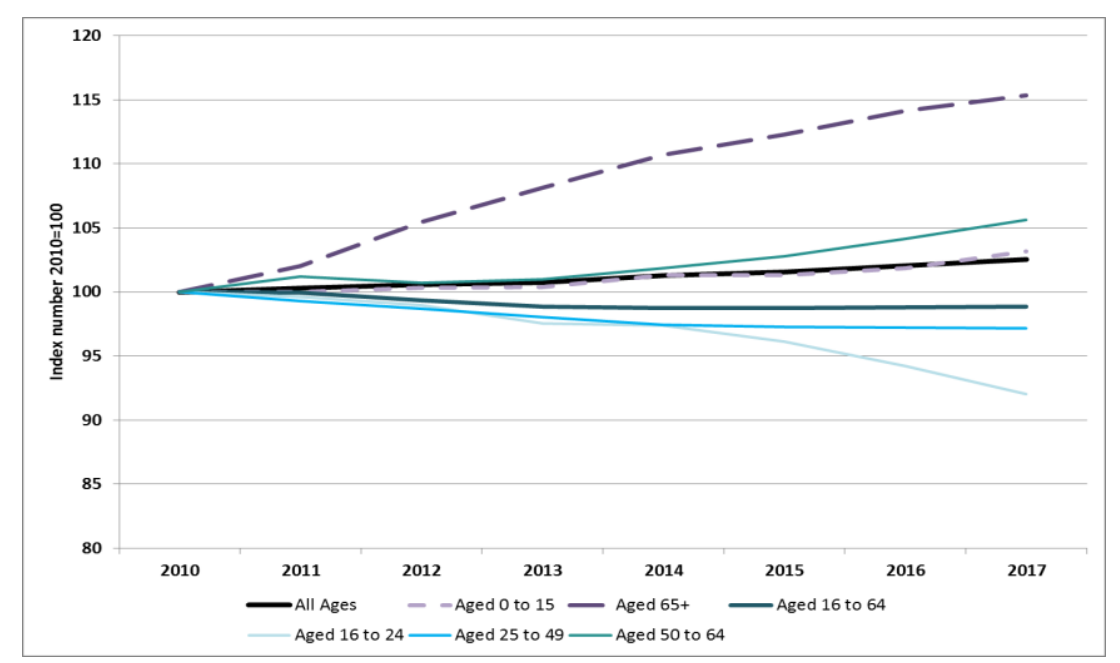

Source: ONS Mid-year population estimates 
The decline in the working age population would have been greater if there had not been net in-migration to Rotherham in the post-2010 period. Data from the ONS Migration Indicators Suite shed some light on migration flows into and out of Rotherham over time.

\section{Migration}

Migration flows can take the form of 'internal migration' when a person moves within the UK or 'international migration' when people move to or from another country. ONS produces estimates for both the in-flows and out-flows of both these types of migration as components of their mid-year population estimates. It is possible to examine the extent to which these impact on the size of the working population in the area over time. The ONS estimates are for the whole population and are derived from a number of data sources. ${ }^{2}$

Table 2.2 indicates that internal migration in-flows and out-flows per year are substantial. On average, approximately 7,500 people move into Rotherham from other parts of the country each year. Whilst this means the average net internal in-migration in any one year is relatively small (20 people), there is some degree of churn amongst the working age population over time. Some residents may leave in one year and return in another. For example, students may register at a doctor's surgery elsewhere in the country while undertaking their studies but eventually return to their home town. Other migrants are likely to be individuals who leave and never return or vice versa. Over the 2010-2017 period this means that there were nearly 53,000 people who moved into Rotherham from other parts of the UK, whilst roughly the same number moved in the opposite direction. This equates to around a fifth of the borough's population moving in or out of the area over an eight year period, indicating a considerable degree of churn in the local population.

Table 2.2: Migration inflows and outflows to and from Rotherham, 2010-2017

\begin{tabular}{|c|c|c|c|c|c|c|c|}
\hline & \multicolumn{3}{|c|}{ Internal migration } & \multicolumn{3}{|c|}{ International migration } & \multirow{2}{*}{$\begin{array}{l}\text { Total net } \\
\text { migration }\end{array}$} \\
\hline & Inflow & Outflow & Net & Inflow & Outflow & Net & \\
\hline 2010-2011 & 6,580 & 6,970 & -390 & 800 & 360 & 440 & 50 \\
\hline 2011-2012 & 7,150 & 7,280 & -130 & 630 & 390 & 240 & 110 \\
\hline 2012-2013 & 6,960 & 7,450 & -490 & 710 & 370 & 340 & -150 \\
\hline 2013-2014 & 7,970 & 7,580 & 380 & 710 & 360 & 340 & 720 \\
\hline 2014-2015 & 7,600 & 7,530 & 70 & 740 & 310 & 430 & 500 \\
\hline $2015-2016$ & 7,540 & 7,420 & 120 & 870 & 360 & 510 & 630 \\
\hline 2016-2017 & 9,160 & 8,600 & 560 & 790 & 390 & 410 & 970 \\
\hline 2010-2017 & 52,950 & 52,830 & 120 & 5,250 & 2,540 & 2,710 & 2,830 \\
\hline $\begin{array}{l}\text { Average } \\
\text { per year }\end{array}$ & 7,560 & 7,550 & 20 & 750 & 360 & 390 & 410 \\
\hline
\end{tabular}

Source: ONS Migration Indicators Suite

The ONS figures for local authorities are calculated for the total population. The national level data indicates that the vast majority - approximately 80 per cent - of internal migration is by working age people. On average, this translates to approximately 6,000 people of

\footnotetext{
2 The migration flows data utilises several data sources including General Practitioner (GP) registrations, National Insurance number (NINo) allocations to overseas nationals, and the International Passenger Survey.
} 
working age moving into and out of Rotherham to or from another destination in the UK per year. Over the 2010-2017 period, this is equivalent to approximately 42,000 working age inmovers and out-movers. However, as the flows generally offset each other each year this results in negligible net in-migration annually over the entire period from 2010 to 2017 of an average of 15 working age net in-migrants per year.

The annual international migration flows are much smaller. On average, 750 international migrants move into Rotherham each year and only 360 emigrate leading to a net contribution to the population of nearly 400 people per year. Over the 2010-2017 period, this equates to an in-flow of 5,250 international migrants, less than half of which is offset by an international migration out-flow of 2,540 people. This leads to international net inmigration of approximately 2,700 people over the period.

Like internal migration, national figures indicate that the vast majority of this involves working age people - approximately 90 per cent. If the same pattern is seen in Rotherham as nationally, on average, net international migration contributes approximately 350 people to Rotherham's working age population each year. Over the 2010 to 2017 period this equates to an additional 2,400 added to the potential workforce to the area.

The combined average net internal and international migration into Rotherham contributes approximately 360 working age people to the potential workforce each year. Given that the overall size of the working age population declined between 2010 and 2017 (by 1.1 per cent), this means the rate of decrease would have been more rapid had there not been some net in-migration to the area (by 2.6 per cent).

\section{Commuting}

Labour markets are rarely self-contained at the scale of a local authority. Some residents live and work within the district, others commute outside the district for work, and some people who work within the district reside in other local authority areas. These commuting patterns impact on the size and characteristics of the workforce filling jobs in the area.

ONS 2011 Travel to Work Areas (TTWAs) are based on 2011 Census data at an LSOA level. Each TTWA is a contiguous area where between two-thirds and three-quarters of all residents live and work within the same area. The calculations are based on the origins and destinations of each resident's home and work address. ${ }^{3}$ All but 11 of Rotherham's 167 LSOAs are within the Sheffield TTWA. The remaining 11, which are located around Wathupon-Dearne, form part of the Barnsley TTWA.

However, TTWAs don't tell us about the scale of commuting flows between districts. It is possible to explore the commuting flows to and from Rotherham by utilising Secure Access Annual Population Survey (APS) data which was obtained as part of this study. Due to sample sizes three annual data files were pooled to create a more robust sample and so the

\footnotetext{
${ }^{3}$ The criteria for defining TTWAs is based on at least 75 per cent of an area's resident workforce work in the area and at least 75 per cent of the people who work in the area also live in the area. The area must also have an economically active population of at least 3,500. For areas with a working population in excess of 25,000 , selfcontainment rates as low as 66.7 per cent were accepted as part of a 'trade-off' between workforce size and level of self-containment.
} 
analysis presented here is on the basis of a three year average between 2015 and 2017 . Full details of the data are included in Appendix $1 .{ }^{4}$

The data for 2015-2017 indicates that there were approximately 160,000 working age residents in Rotherham which is in line with the MYEs reported above. Of these 113,600 residents were in employment of which only 57 per cent worked within the district $(65,000)$. Not all residents in employment work in Rotherham as there are fewer jobs than residents in employment. Nearly 100,000 people have their workplace within the Rotherham borough area. Of these 65 per cent are local residents and the remaining 35 per cent are from areas outside the district boundaries. The vast majority of all local jobs are filled with workers from within the Combined Authority area (94 per cent), so most inward commuters travel from elsewhere in South Yorkshire.

This means that Rotherham is a significant net exporter of workers to other areas $(13,700)$. Table 2.3 indicates that this net-commuting figure hides substantial flows of workers into and out of Rotherham on a daily basis; 34,800 and 48,500 respectively. More than two in five of all Rotherham residents in employment work outside the district $(48,500 ; 43$ per cent of residents in employment). Approximately half of these out-commuters work in Sheffield $(24,700 ; 22$ per cent of residents in employment); a further one in five work in Barnsley or Doncaster (10,800; 10 per cent of residents in employment); and a similar proportion travel to outside the SCR for work (9,500; 8 per cent of residents in employment).

Table 2.3: Commuting in-flows to and out-flows from Rotherham, 16-64 year olds in employment, 2015-2017

\begin{tabular}{lrrr}
\hline & $\begin{array}{c}\text { In-flow } \\
\text { from }\end{array}$ & $\begin{array}{c}\text { Out- } \\
\text { flow to }\end{array}$ & Net \\
\hline Barnsley & 9,400 & 5,000 & 4,400 \\
Doncaster & 6,800 & 5,800 & 900 \\
Sheffield & 13,100 & 24,700 & $-11,500$ \\
Other SCR & & & \\
Outside SCR & 2,000 & 3,500 & $-1,500$ \\
\hline Total & 3,500 & 9,500 & $-6,000$ \\
\hline
\end{tabular}

Source: Annual Population Survey

\footnotetext{
${ }^{4}$ There are small differences in the data for the same time period if the APS data available from NOMIS and the raw data available via Secure Access are compared. This is due to weighting procedures for annual and pooled data. Consistency has been aimed throughout the report by reporting figures from one data source within each section. Sometimes there will be small differences across sections in absolute numbers or percentages depending on which source they are reported from.

${ }^{5}$ Sheffield City Region consists of nine local authorities: the four within the combined authority (Sheffield, Doncaster, Rotherham and Barnsley), and Chesterfield, North East Derbyshire, Bolsover, Derbyshire Dales and Bassetlaw
} 
Table 2.4: Commuting in-flows and out-flows for districts within Sheffield City Region, 16-64 year olds in employment, 2015-2017

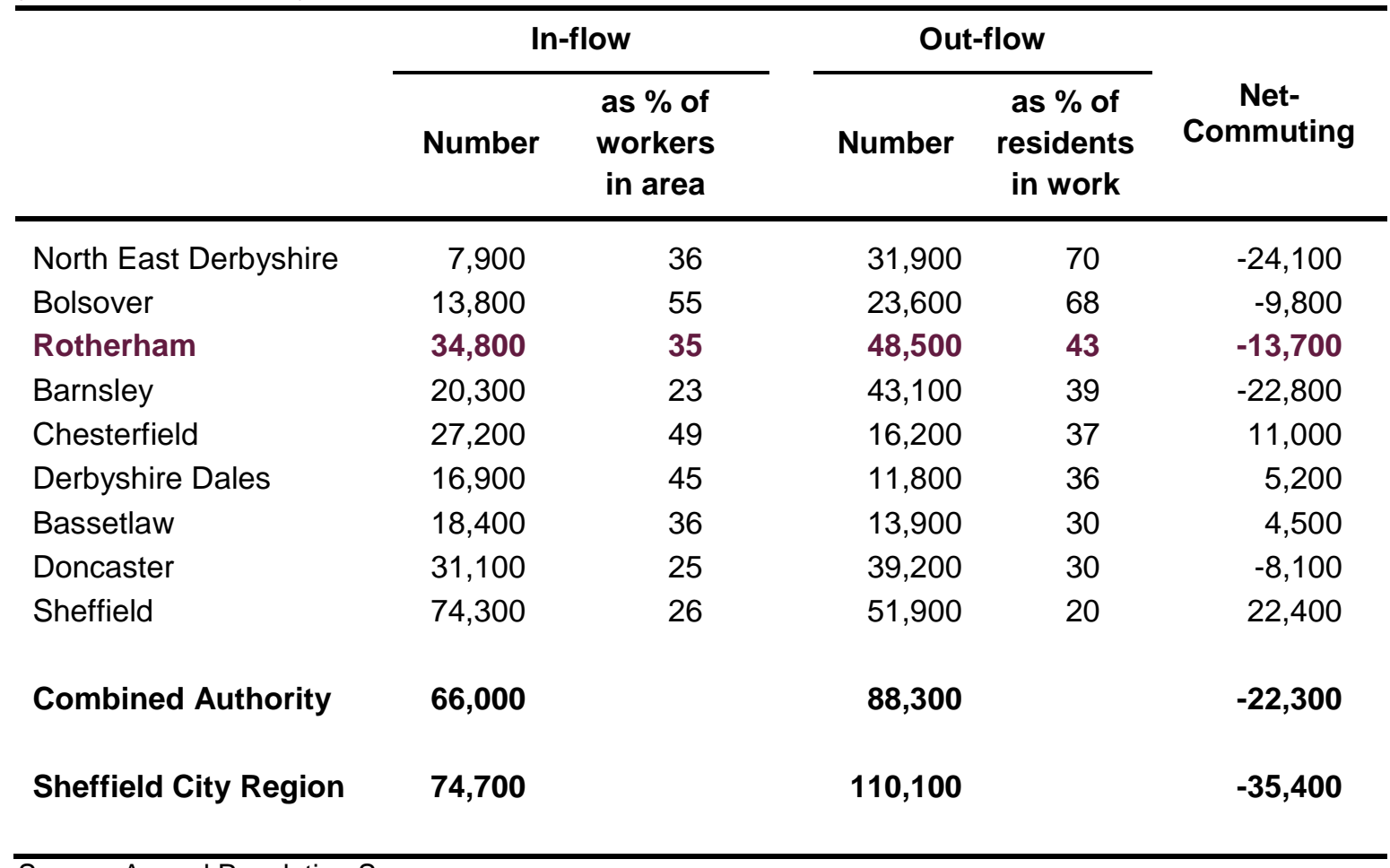

Source: Annual Population Survey

Table 2.4 compares the side of commuting flows as a proportion of jobs in the area (in-flows) or residents in employment (out-flows) for all districts within SCR. With the exception of North East Derbyshire and Bolsover, which have exceptionally high rates of out-commuting due to their geographic location and urban/rural nature ${ }^{6}$ Rotherham has the highest rate of commuting out-flows compared to the remaining districts within the SCR (43 per cent of all residents in work). Rotherham also has a notably higher rate of in-commuters taking local jobs than the other districts within the combined authority (35 per cent in Rotherham and between 23 to 26 per cent in Sheffield, Barnsley and Doncaster). Potentially this could be an indication of mismatch in the characteristics of the supply and demand for labour in the area or potentially a skills mismatch in residents compared to the work available locally.

The patterns for in-commuting and out-commuting are complex. Figure 2.2 indicates that net-commuting flows for Rotherham have also been gradually decreasing over time. There were on average 15,300 net out-commuters between 2010 and 2012 and this had fallen to 13,700 between 2015 and 2017 . This change in net commuting patterns may be a product of fluctuations in commuting in-flows, out-flows or both. Declining net-commuting may reflect changes in labour force participation amongst residents; their characteristics and human capital - including skills, qualifications and their ability to compete for jobs locally or further afield; or the demand for labour in surrounding areas.

\footnotetext{
${ }^{6}$ North East Derbyshire forms a ring around three sides of Chesterfield and is also adjacent to Sheffield's boundary leading to large commuting flows to these areas for job opportunities. These two districts are the destination for work for two-thirds of the out-commuters (21,400 out of 31,900 out commuters). Bolsover has a relatively small population $(2017=79,100)$ and is relatively rural (nearly half of the population). Residents travel to surrounding districts for job opportunities; 60 per cent of these out-commuters $(23,600)$ work outside the Sheffield City Region.
} 
Figure 2.2: Net out-commuting from Rotherham, 2010/2012 to 2015/2017

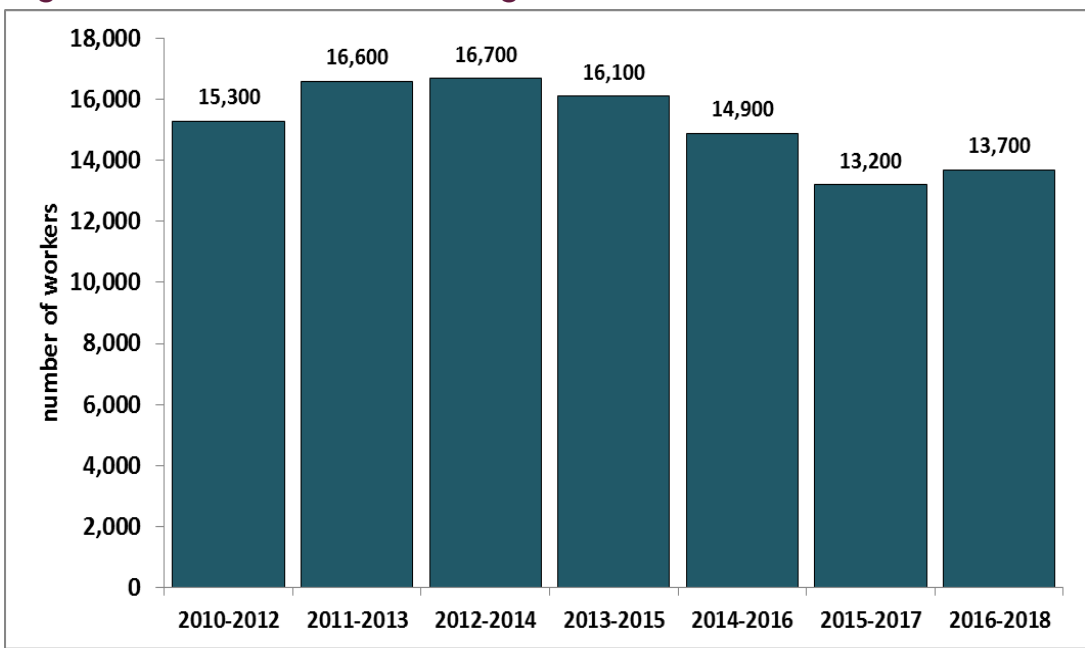

Source: Annual Population Survey

\section{Job density}

As the complex commuting patterns show, jobs created in the district so not necessarily go to residents in the area. In this light, improvement in skills and educational attainment amongst residents will not necessarily translate into more of them filling jobs within the area in competition with candidates from elsewhere. To begin to consider the relationship between these factors, Table 2.5 provides the number of jobs in each SCR local authority area per working age resident (jobs density), alongside the share of jobs within each district filled by local residents and the local resident employment rate.

Table 2.5: Jobs density and residents employed in the area, 2015-2017

\begin{tabular}{lccc}
\hline & Jobs Density & $\begin{array}{c}\text { Live and work in } \\
\text { district, as \% of } \\
\text { employed } \\
\text { residents }\end{array}$ & $\begin{array}{c}\text { Resident } \\
\text { employment rate }\end{array}$ \\
\hline Derbyshire Dales & 0.94 & 64 & 82 \\
Chesterfield & 0.84 & 63 & 71 \\
Bassetlaw & 0.80 & 70 & 70 \\
Sheffield & 0.77 & 80 & 69 \\
Doncaster & 0.67 & 70 & 71 \\
Rotherham & $\mathbf{0 . 6 3}$ & 57 & 70 \\
Barnsley & 0.53 & 61 & 72 \\
Bolsover & 0.53 & 32 & 73 \\
North East Derbyshire & 0.38 & 30 & 79 \\
Combined Authority & $\mathbf{0 . 6 5}$ & $\mathbf{8 6}$ & $\mathbf{7 4}$ \\
Sheffield City Region & $\mathbf{0 . 6 8}$ & $\mathbf{8 7}$ & $\mathbf{7 5}$ \\
\hline
\end{tabular}

Source: Annual Population Survey 
Job density is a measure of how many jobs there are in an area relative to the size of the potential workforce in that area (the number of working age residents). DWP has previously used these as a way of investigating the ratio of labour supply and demand in a given locality. So, in Rotherham the figure of 0.63 indicates that there are 63 jobs for every 100 working age residents; this is on par with the ratio seen in the Combined Authority (0.65) and not much lower than that seen across the city region (0.68). The table indicates that there is not a straightforward relationship between the concentration of jobs in each local area and the local employment rate. No correlation exists $(R=0.01)$ between the two variables ${ }^{7}$ across SCR, albeit this is based on a small sample of the nine districts within SCR. A combination of factors including the strength of aggregate labour demand in the wider functional labour market; the types of jobs and levels of pay available; and local residents having the skills and qualifications to compete for jobs available may all be more important factors in determining the overall employment rate amongst residents.

There is, however, a strong relationship between the job density in the local area and the proportion of residents in employment who also have a workplace within the district $(R=0.72)$. So, on average, as the number of jobs relative to the size of the population increases locally, then a higher proportion of working age residents fill these jobs. Increasing the number of local jobs available and supporting residents to be equipped to compete for these jobs should benefit both local residents and local employers.

Table 2.5 also highlights that Rotherham's employment rate is amongst the lowest in the City Region. The following chapter therefore looks at trends in employment and economic activity in Rotherham over time to understand the reasons which might underpin these economic indicators.

\footnotetext{
${ }^{7}$ This also held when tested against an employment rate excluding economically inactive students from the denominator $(\mathrm{R}=0.10)$.
} 


\section{Labour market characteristics of the workforce in Rotherham}

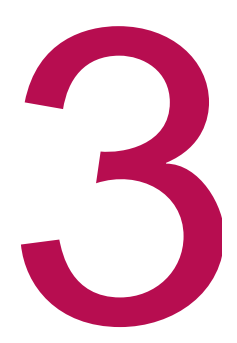

\section{Introduction}

First indications from Chapter 2 are that Rotherham has a relatively low employment rate compared to many of the other districts within Sheffield City Region (SCR) and the prevailing national rate. It is important, therefore, to get behind this headline indicator to understand the factors contributing to the local employment rate amongst residents. This chapter looks at the trends in labour market participation, employment, skills and qualifications relative to the wider region. The analysis in this section is based on the Annual Population Survey (APS). Due to sampling variability in the APS, three year averages are used to provide more robust estimates at a local level.

\section{Employment rate}

Table 3.1 provides an overview of the employment rate in Rotherham alongside the other districts in the Combined Authority (CA). The employment rate in 2016-2018 in Rotherham (71.8 per cent for 16-64 year olds) is 2.6 percentage points below the national benchmark. However, the historically high national rate is buoyed up the strong economic performance in much of southern Britain where the South East, East and South West regions all currently have employment rates of between 77.7 and 78.7 per cent; many of the districts within these regions have employment rates of over 80 per cent.

At first glance the employment rate in Rotherham (71.8 per cent) is higher than in the CA (70.7 per cent) and Sheffield (69.7 per cent), and on a par with the average for the whole of SCR (71.9 per cent). However, this needs to be considered in the light of the impact that large numbers of economically inactive students has on local employment rates in large university cities like Sheffield. The two universities have over 60,000 students between them equivalent to one in six of the working age population. This also has the knock-on effect of lowering the employment rates for the CA and SCR.

Table 3.1 therefore provides an alternative employment rate that excludes the economically inactive students to remove the distortion that they make on the benchmark areas. In Rotherham the alternative employment rate is 74.8 per cent which is now lower than Sheffield (76.3 per cent), the CA (75.2 per cent) and SCR (75.9 per cent). The gap between Rotherham and national benchmarks increases to 4.2 percentage points once students have been taken into account. 


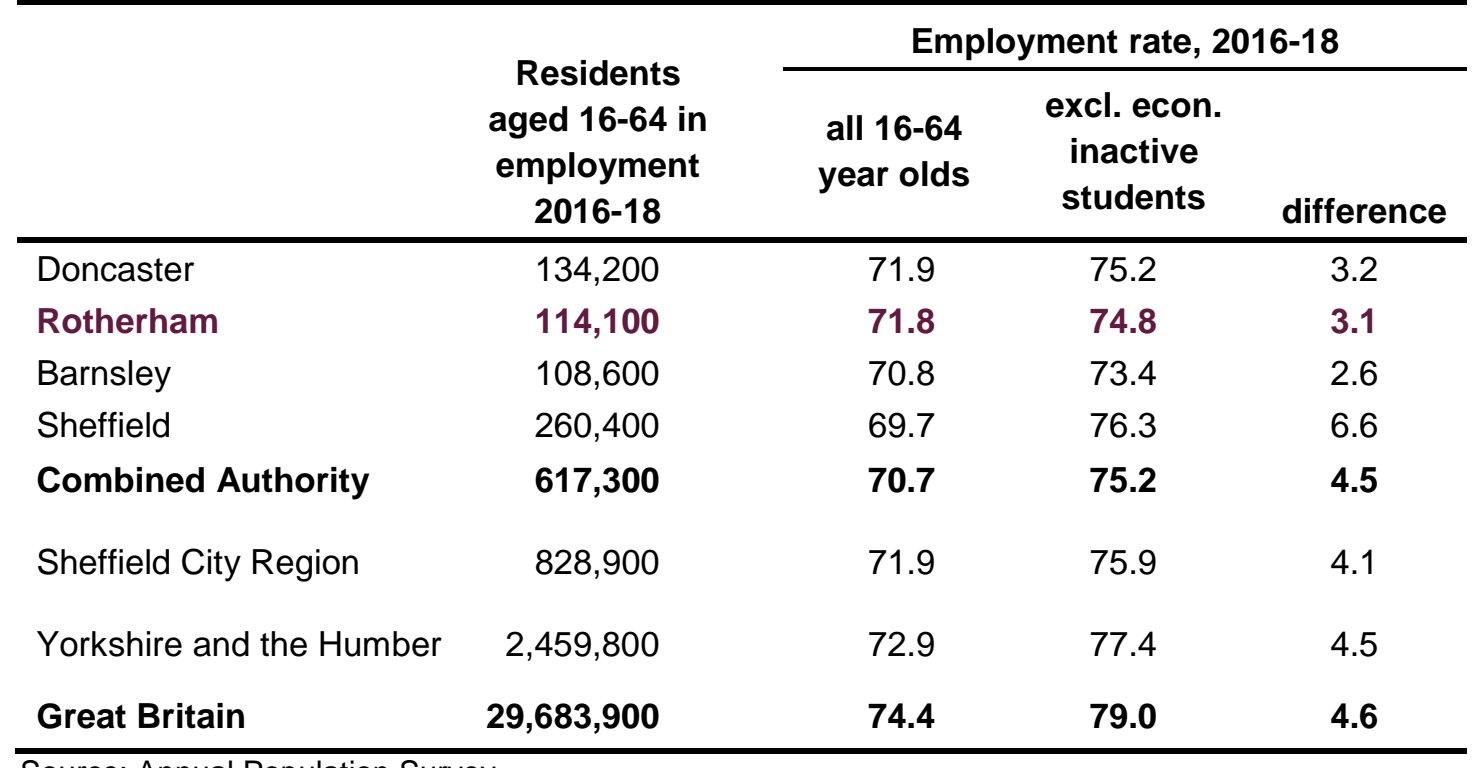

Source: Annual Population Survey

The employment rate in Rotherham for all 16-64 year old residents has been improving over time and at a faster rate than seen nationally (Table 3.2). This has narrowed the gap between the Rotherham and the national employment rates from consistently above four percentage points for all of the time periods since 2011-2013 to 2.6 percentage points in 2016-2018 (Figure 3.1).

Table 3.2: Employment rate in Rotherham, 2010-2012 to 2016-2018

\begin{tabular}{lccc}
\hline & \multicolumn{3}{c}{ Employment rate, all 16-64 year olds } \\
\cline { 2 - 4 } & $\mathbf{2 0 1 0 - 2 0 1 2}$ & $\mathbf{2 0 1 6 - 2 0 1 8}$ & Difference \\
\hline Doncaster & 65.6 & 71.9 & 6.4 \\
Rotherham & 66.7 & 71.8 & 5.1 \\
Barnsley & 65.9 & 70.8 & 4.9 \\
Sheffield & 65.1 & 69.7 & 4.6 \\
Combined Authority & 65.6 & $\mathbf{7 0 . 7}$ & $\mathbf{5 . 1}$ \\
Sheffield City Region & 67.0 & 71.9 & 4.9 \\
& & & \\
Yorkshire and Humber & 68.2 & 72.9 & 4.7 \\
Great Britain & & & \\
\hline
\end{tabular}

Source: Annual Population Survey 
Figure 3.1: Resident employment rate, 2010/2012 to 2016/2018

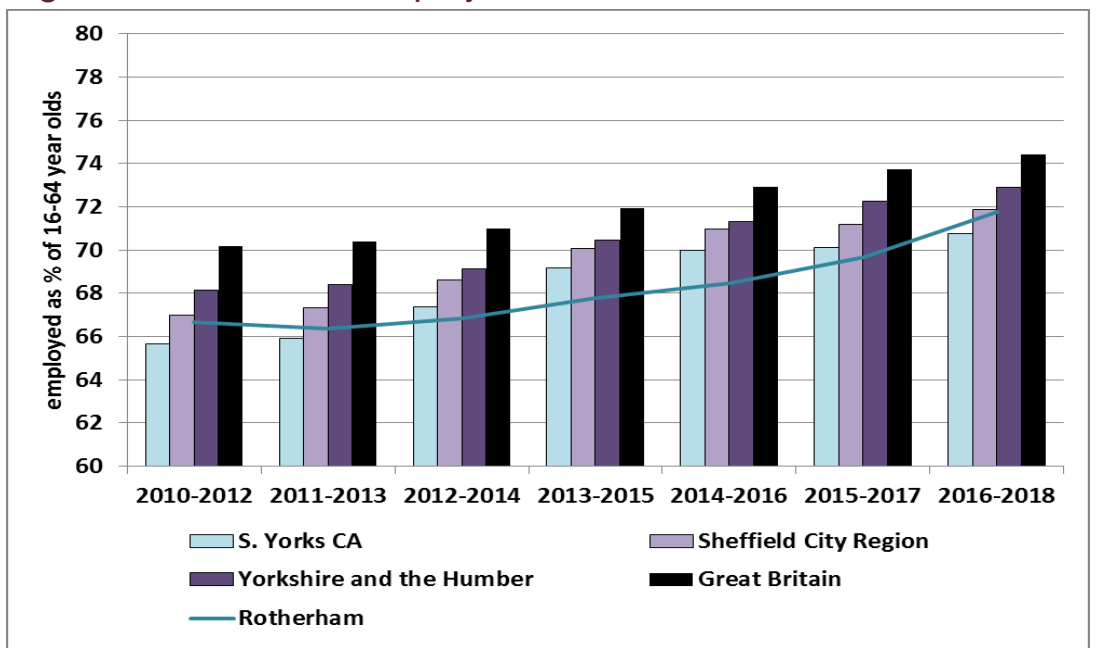

Source: Annual Population Survey

Whereas the resident employment rate has improved faster in Rotherham than nationally this has not been the case for the growth in the number residents in employment (Table 3.3). By 2016-2018, an additional 5,900 residents were in employment compared to 2010-2012. This increase of 5.5 per cent lagged behind the growth seen in the CA (9.3 per cent), in SCR (7.8 per cent) and nationally (7.9 per cent).

Table 3.3: Employment growth in Rotherham, 2010-2012 to 2016-2018

\begin{tabular}{|c|c|c|c|c|}
\hline & \multicolumn{2}{|c|}{ Residents in Employment } & \multicolumn{2}{|c|}{$\begin{array}{c}\text { Change between } \\
2010-2012 \text { to } 2016-2018\end{array}$} \\
\hline & $2010-2012$ & $2016-2018$ & Number & Percentage \\
\hline Barnsley & 97,000 & 108,600 & 11,600 & 12.0 \\
\hline Sheffield & 234,700 & 260,400 & 25,700 & 11.0 \\
\hline Doncaster & 124,800 & 134,200 & 9,400 & 7.5 \\
\hline Rotherham & 108,200 & 114,100 & 5,900 & 5.5 \\
\hline Combined Authority & 564,600 & 617,300 & 52,700 & 9.3 \\
\hline Sheffield City Region & 768,900 & 828,900 & 60,000 & 7.8 \\
\hline Yorkshire and Humber & $2,296,500$ & $2,459,800$ & 163,300 & 7.1 \\
\hline Great Britain & $27,522,100$ & $29,683,900$ & $2,161,800$ & 7.9 \\
\hline
\end{tabular}

Figure 3.2 shows that this weaker than average employment growth amongst Rotherham residents was due to a contraction in employment in the first half of the period but a much stronger performance in the latter part of the period.

As discussed in Chapter 2, the labour market dynamics in an area are underpinned by complex commuting patterns. Rotherham is a net exporter of 13,700 commuters to districts within the SCR and further afield. Only 57 per cent of residents in employment actually have a workplace within the district and the remaining 43 per cent work elsewhere. Just over a third (35 per cent) of all workers in the district live elsewhere. 
Figure 3.2: Resident employment, index numbers, 2010/2012 to 2016/2018

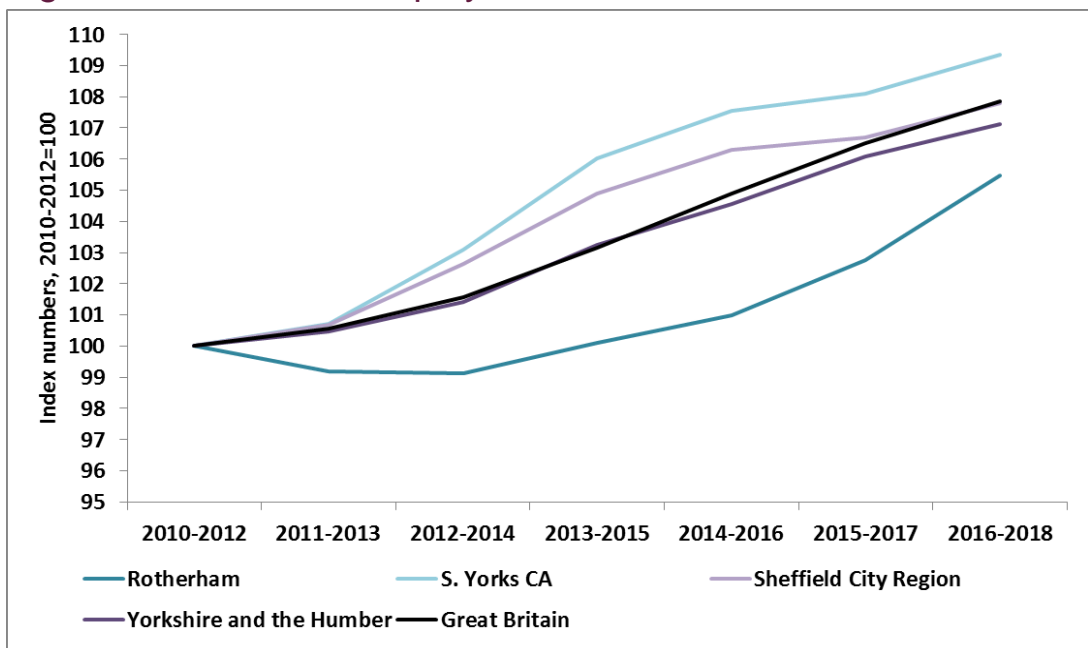

Source: Annual Population Survey

Table 3.4 shows that the number of workers with jobs in Rotherham increased by 7,600 (8.2 per cent) between 2010-2012 and 2016-2018. This was more rapid than the growth in resident employment over the period (5.5 per cent). It was also faster than the national rate of growth (7.9 per cent) and that seen in the CA (6.7 per cent) or in the SCR (6.9 per cent).

Table 3.4: Growth in the number of workers with a workplace in Rotherham, 2010-2012 to 2016-2018

\begin{tabular}{|c|c|c|c|c|}
\hline & \multicolumn{2}{|c|}{ Workers in area } & \multicolumn{2}{|c|}{$\begin{array}{c}\text { Change between } 2010- \\
2012 \text { to } 2016-2018\end{array}$} \\
\hline & 2010-2012 & 2016-2018 & Number & Percentage \\
\hline Sheffield & 260,400 & 287,100 & 26,700 & 10.3 \\
\hline Rotherham & 92,900 & 100,500 & 7,600 & 8.2 \\
\hline Doncaster & 123,200 & 125,300 & 2,100 & 1.7 \\
\hline Barnsley & 80,300 & 81,200 & 900 & 1.2 \\
\hline Combined Authority & 556,800 & 594,200 & 37,400 & 6.7 \\
\hline Sheffield City Region & 738,300 & 789,600 & 51,200 & 6.9 \\
\hline Yorkshire and the Humber & $2,273,100$ & $2,448,700$ & 175,500 & 7.7 \\
\hline Great Britain & $27,289,200$ & $29,437,000$ & $2,147,800$ & 7.9 \\
\hline
\end{tabular}

Figure 3.3 shows a similar trajectory of growth in workers in Rotherham as depicted in the earlier chart for the trend in resident employment. The workforce contracted in the first part of the period, recovered post 2012-2014, with more rapid growth post 2014-2016, and outperforming the benchmarks post 2015-2017. 
Figure 3.3: Growth in the number of workers with a workplace in Rotherham, index numbers, $2010 / 2012$ to $2016 / 2018$

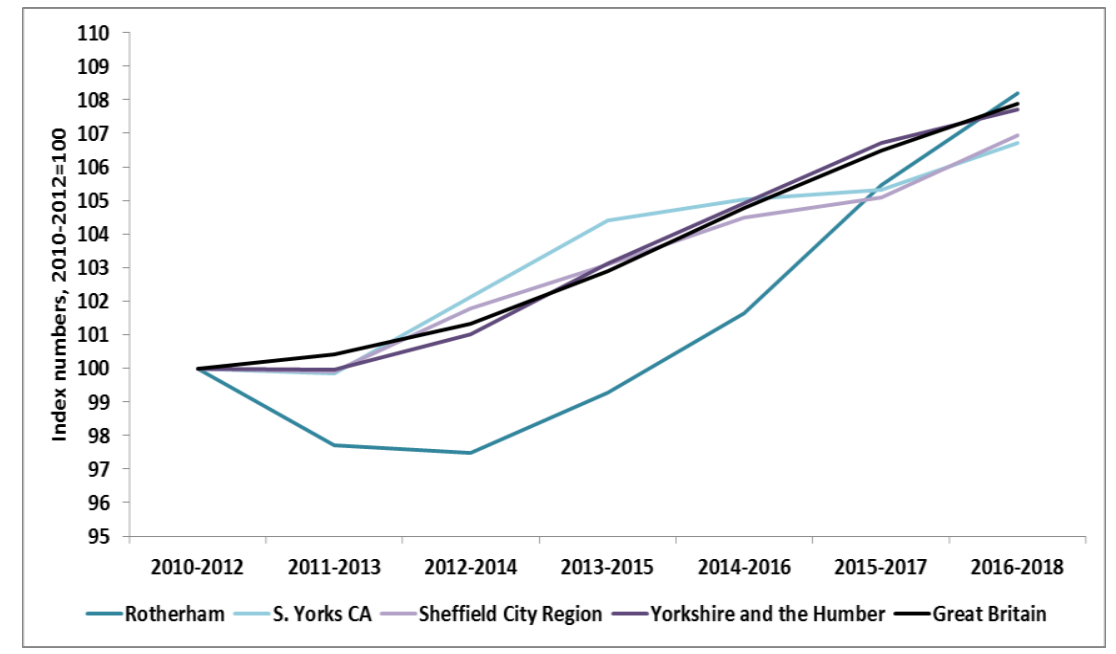

Source: Annual Population Survey

\section{Economic activity}

It can be seen from the figures above that labour supply as well as demand impact on employment rates. The more people who participate in the workforce the greater potential there is to increase the local employment rate. Labour market participation is measured as the number of people who are economically active: i.e., those who are employed or unemployed.

Table 3.5: Economic activity rates in Rotherham, 2010-2012 to 2016-2018

\begin{tabular}{lccc}
\hline & \multicolumn{3}{c}{ Economic activity rate } \\
\cline { 2 - 4 } & $\mathbf{2 0 1 0 - 2 0 1 2}$ & $\mathbf{2 0 1 6 - 2 0 1 8}$ & $\begin{array}{c}\text { percentage } \\
\text { point change }\end{array}$ \\
\hline Doncaster & 74.0 & 76.8 & 2.9 \\
Rotherham & 74.7 & 76.3 & 1.6 \\
Barnsley & 73.0 & 75.5 & 2.4 \\
Sheffield & 72.0 & 74.7 & 2.7 \\
Combined Authority & 73.1 & 75.6 & $\mathbf{2 . 5}$ \\
Sheffield City Region & 74.1 & 76.2 & 2.1 \\
Yorkshire and the Humber & 75.1 & 76.9 & 1.8 \\
Great Britain & 76.3 & $\mathbf{7 8 . 1}$ & $\mathbf{1 . 8}$ \\
\hline
\end{tabular}

Source: Annual Population Survey

Table 3.5 indicates that 76.3 per cent of Rotherham residents were economically active in 2016-2018. Whilst this is below the national average (78.1 per cent) it is higher than both the CA (75.6 per cent) and SCR (76.2 per cent). As previously shown, the figures for Sheffield (and other university cities), and consequently the CA and SCR, are distorted to some extent due to the impact of large numbers of economically inactive university students who live in Sheffield (Table 3.6). This is not generally seen as a 'negative' form of economic inactivity. It is not that these are inactive residents who are not participating in the workforce because they lack aspirations to work or face barriers to work, but primarily because they are delaying their entry to the workforce while they enhance their skills and qualifications. 
Table 3.6: Economic activity rate in Rotherham excluding students, 2016-2018

\begin{tabular}{lccc}
\hline & \multicolumn{3}{c}{ Economic activity rate, 2016-2018 } \\
\cline { 2 - 4 } & $\begin{array}{c}\text { all 16-64 } \\
\text { year }\end{array}$ & $\begin{array}{c}\text { excl. eco. } \\
\text { inactive } \\
\text { students olds }\end{array}$ & difference \\
\hline Sheffield & 74.7 & 81.7 & 2.8 \\
Doncaster & 76.8 & 80.3 & 3.5 \\
Rotherham & 76.3 & 79.5 & 3.3 \\
Barnsley & 75.5 & 78.3 & 7.0 \\
Combined Authority & 75.6 & 80.4 & 4.8 \\
Sheffield City Region & 76.2 & 80.5 & 4.3 \\
Yorkshire and the Humber & 76.9 & 81.7 & 4.8 \\
Great Britain & 78.1 & 82.9 & 4.8 \\
\hline
\end{tabular}

Source: Annual Population Survey

Table 3.5 also shows that there has been an increase in economic activity rates of 1.6 percentage points in Rotherham since 2010-2012. This is slightly below the increase in the national economic activity rate but the rate of increase in Rotherham has generally lagged behind all the areas presented in the table.

Table 3.7 presents the change in the number of economically active people between 20102012 and 2016-2018. This shows that the number remains virtually unchanged over the period. The rise in economic activity rates is therefore a product of a shrinking denominator (the working age population) rather than a substantive increase in the number (more economically active people).

The trend over time in the three year averages for economic activity rates is shown in Figure 3.4. There is a notable upturn at the end of the time series for Rotherham which echoes that seen earlier in the resident employment rate and deserves further investigation. A smoothed time series utilising averaged four quarterly annual files between 2010 and 2018 has also been produced (Figure 3.5). ${ }^{8}$ This shows that whilst the national rate for economic activity increases steadily over time, at a local authority district level there is a degree of fluctuation over the period. This does not seem to be wholly attributable to sampling variability given the nature of the patterns across individual authorities in the CA. Again the upturn at the end of the series for Rotherham is notable. Potentially, this shows a relatively recent improvement in the number of people participating in the workforce. The recent fall in economic inactivity at a national level has also been commented on by the Learning and

\footnotetext{
${ }^{8}$ For example, the data point for Q1 2010 consists of the average of rates for 4 annual files: Apr 2009-Mar 2010, Jul 2009-Jun 2010, Oct 2009-Sep 2010 and Jan 2010-Dec 2010. The next data point drops the first file and includes the next.
} 
Table 3.7: Economically active in Rotherham, 2010-2012 to 2016-2018

\begin{tabular}{lrrrrr}
\hline & \multicolumn{2}{c}{ Economically Active } & & \multicolumn{2}{c}{$\begin{array}{c}\text { Change between 2010-2012 } \\
\text { to 2016-2018 }\end{array}$} \\
\cline { 2 - 3 } \cline { 6 - 6 } \cline { 5 - 6 } & $\mathbf{2 0 1 0 - 2 0 1 2}$ & $\mathbf{2 0 1 6 - 2 0 1 8}$ & & Number & Percentage \\
\hline Barnsley & 107,500 & 115,800 & & 8,400 & 7.8 \\
Sheffield & 259,300 & 278,900 & & 19,600 & 7.6 \\
Doncaster & 140,800 & 143,300 & & 2,500 & 1.8 \\
Rotherham & 121,100 & 121,400 & & 200 & $\mathbf{0 . 2}$ \\
Combined Authority & $\mathbf{6 2 8 , 7 0 0}$ & $\mathbf{6 5 9 , 4 0 0}$ & & $\mathbf{3 0 , 7 0 0}$ & $\mathbf{4 . 9}$ \\
Sheffield City Region & 850,300 & 879,000 & & 28,700 & 3.4 \\
Yorkshire and the Humber & $2,530,700$ & $2,596,800$ & & 66,100 & 2.6 \\
Great Britain & $\mathbf{2 9 , 9 1 7 , 4 0 0}$ & $\mathbf{3 1 , 1 5 9 , 0 0 0}$ & & $\mathbf{1 , 2 4 1 , 7 0 0}$ & $\mathbf{4 . 2}$ \\
\hline
\end{tabular}

Source: Annual Population Survey

Figure 3.4: Economic activity rates in Rotherham, 2010-2012 to 2016-2018

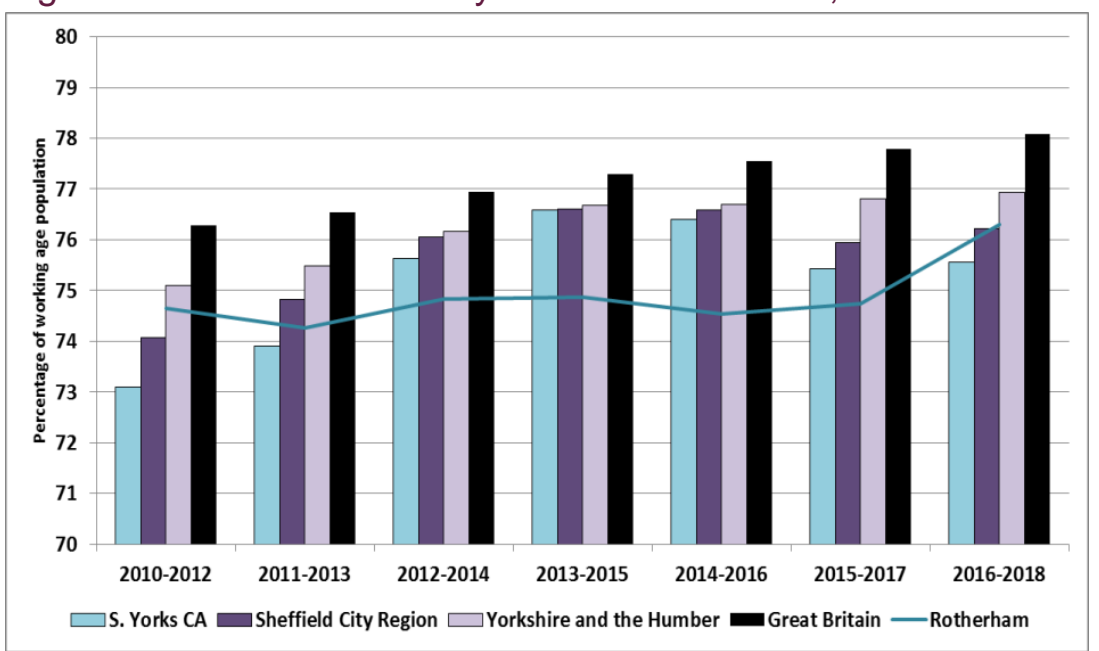

Source: Annual Population Survey

Figure 3.5: Smoothed time series of economic activity rates in Rotherham, 2010-2012 to 2016-2018

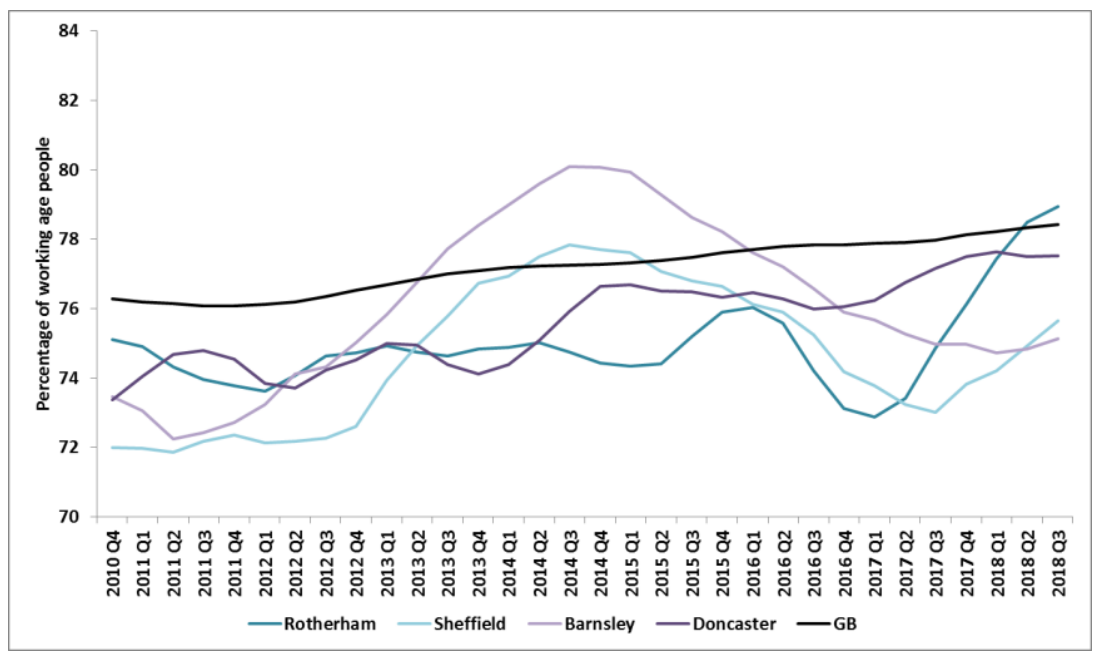

Source: Annual Population Survey 
Work Institute in their commentary of the most recent release of ONS labour market statistics. ${ }^{9}$

The following chapter examines recent trends in unemployment in Rotherham and the barriers to work that individuals may face. The extent to which economic activity varies across particular groups of residents is also examined including for women, by age and for ethnic minority groups.

${ }^{9}$ Learning and Work Institute (2019) Labour market LIVE from Learning and Work Institute, 22 January 2019 


\section{Unemployment in Rotherham}

\section{Introduction}

The previous chapters have shown that labour market participation amongst working age residents in Rotherham is rising, as is employment. However, depending on the strength of labour demand in and around Rotherham, an increase in labour supply can result in unemployment for some if there are not enough jobs to go around. Alternatively, even as employment opportunities increase unemployment amongst residents can still exist if there is a skills mismatch between the types of jobs available and the ability of the local workforce to compete for these jobs.

The types of work or wage levels available can also contribute to certain groups within the potential labour force, for example women with childcare responsibilities or childcare costs, feeling deterred from actively participating in the workforce. For other groups, such as fulltime students or those looking after a family or children, being economically inactive is often not due to barriers to work but a pro-active choice. It is important to understand the trends and characteristics of both the unemployed and economically inactive so that local initiatives can focus on those who want to participate in the workforce. By enhancing their skills and qualifications they may be better placed to compete for the jobs available or improve the quality of jobs they can access.

APS and LFS data contains a range of variables that tells us about some of the barriers that sub-groups of the population might face when trying to gain a job. Unfortunately, some of these variables around skills, barriers to work and job search are only available on the quarterly LFS data rather than the annual APS data files. This means that information on factors of interest is not readily available at a local level. However, whilst the numbers of particular groups vary by place, for example the size of the local ethnic minority population, the characteristics of these sub-groups are often similar across different locations. Where local data is not available an exploration of the data for England as a whole is used to highlight the common barriers faced.

\section{Measuring unemployment}

There are a number of different ways of measuring unemployment at a local scale. The first classifies people as ILO unemployed if they are not in work and are actively searching for and available for work. This is the government's preferred measure of unemployment and is 
not dependent on an individual's benefit's status. Enhanced local authority based data is available from NOMIS via modelled ILO unemployment data which is sourced from the APS.

Second, there is an official Claimant Count of those who are on unemployment related benefits. Historically this was based on those on Unemployment Benefit and since 1996 includes those claiming Jobseeker's Allowance (JSA). Since 2013, Universal Credit ${ }^{10}$ (UC) has gradually been introduced across the country. Over time, this means that an increasing proportion of unemployment related benefit claimants are claiming UC. Whilst the number of UC claimants was relatively small initially, since 2016 full service UC has been rolled out to the majority of new claimants across the entire county. Rotherham moved over to the full service UC in mid-July 2018. For a full discussion of the implications for claimants and employment services in Rotherham see Beatty and Povey (2018). ${ }^{11}$ Between May 2013 and March 2015, the Claimant Count includes all out of work Universal Credit claimants as well as all JSA claimants. Since April 2015, the Claimant Count was amended to include those who are on UC and required to search for work and be available for work, as well as JSA claimants.

A broader group of claimants will be expected to search for work under the UC rules. For example, partners of claimants or people required to look for additional work because they work too few hours or their earnings are below a specified pay threshold. This means that the number of people included within the Claimant Count series is higher than would have been otherwise, even if labour market conditions remain unchanged.

Subsequently, the Office for National Statistics (ONS) has stated that the Claimant Count is no longer a reliable economic indicator. To address this issue the ONS have released a new Alternative Claimant Count of the number of people claiming unemployment related benefits. This third unemployment measure counts how many people would have been on UC or JSA and searching for work if the full UC system had been in place since 2013 and captures the broader range of people UC now covers. ONS states that this is a more consistent local measure of unemployed claimants over time and gives a better indication of labour market change.

Figure 4.1 presents each of these three measures over time for Rotherham. The numbers unemployed are expressed as a percentage of working age people in the area. These show that unemployment has fallen on all three measures between 2013 and 2018. The Alternative Claimant Count is consistently higher than the Claimant Count as it includes a wider group of people who would be expected to search for work. By early 2017, this measure is very much in line with the ILO unemployment rate.

By September 2018 the Alternative Claimant Count is 3.8 per cent of the working age population, ILO unemployment rate stands at 3.9 per cent and the Claimant Count stands at 2.6 per cent (Table 4.1). The number of people on the Claimant Count more than halved between 2013 and 2018 (-52.9 per cent decrease; 4,690 fewer) and this was a greater decline than seen nationally (40.4 per cent).

\footnotetext{
${ }^{10} \mathrm{UC}$ is replacing six main income-related working age benefits including: income related-JSA, income related ESA, Income Support, Housing Benefit, Child Tax Credits and Working Tax Credits.

${ }^{11}$ See Beatty, C. and Povey, L. (2018) Universal Credit in Rotherham: A transition to full service
} 
Figure 4.1: Alternative unemployment rates in Rotherham, 2013-2018

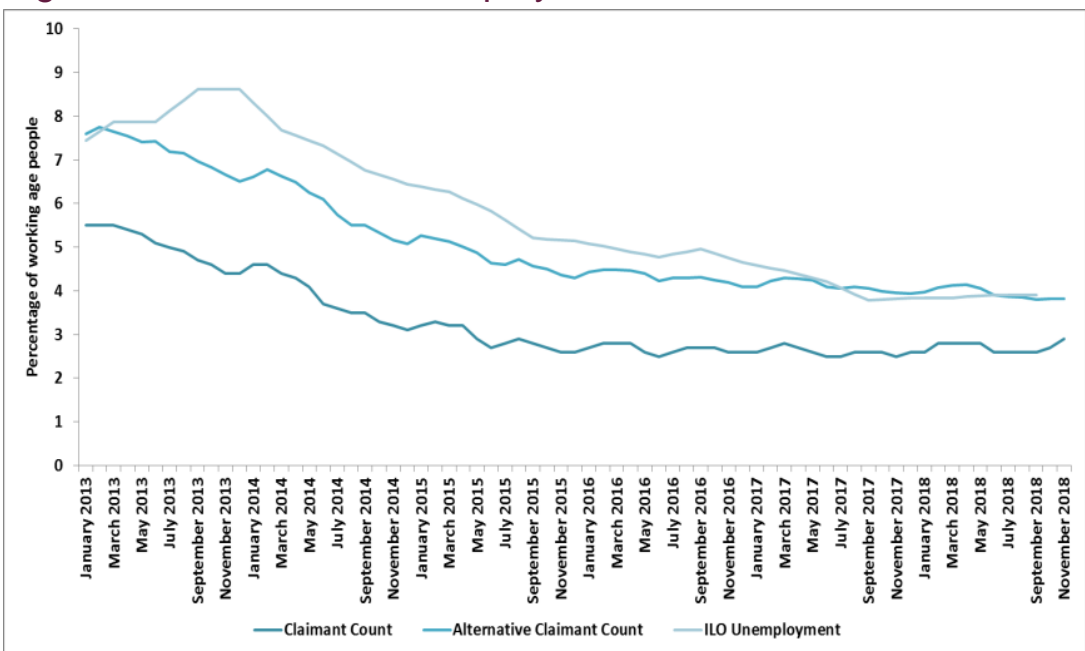

Sources: DWP, ONS

Table 4.1: Alternative unemployment measures, 2013-2018

\begin{tabular}{|c|c|c|c|c|}
\hline & $\begin{array}{c}\text { January } \\
2013\end{array}$ & $\begin{array}{c}\text { September } \\
2018\end{array}$ & Change & $\begin{array}{c}\text { Percentage } \\
\text { change }\end{array}$ \\
\hline \multicolumn{5}{|l|}{ Rotherham } \\
\hline ILO unemployed & $\begin{array}{r}12,700 \\
7.9\end{array}$ & $\begin{array}{r}6,300 \\
3.9\end{array}$ & $\begin{array}{r}-6,400 \\
-4.0\end{array}$ & -50.4 \\
\hline Alternative Claimant Count & $\begin{array}{r}12,250 \\
7.6\end{array}$ & $\begin{array}{r}6,130 \\
3.8\end{array}$ & $\begin{array}{r}-6,120 \\
-3.8\end{array}$ & -50.0 \\
\hline Claimant Count & $\begin{array}{r}8,860 \\
5.5 \\
\end{array}$ & $\begin{array}{r}4,180 \\
2.6 \\
\end{array}$ & $\begin{array}{r}-4,690 \\
-2.9 \\
\end{array}$ & -52.9 \\
\hline \multicolumn{5}{|l|}{ Great Britain } \\
\hline ILO unemployed & $\begin{array}{r}2,446,200 \\
6.2\end{array}$ & $\begin{array}{r}1,366,800 \\
3.4\end{array}$ & $\begin{array}{r}-1,079,400 \\
-2.8\end{array}$ & -44.1 \\
\hline Alternative Claimant Count & $\begin{array}{r}2,121,810 \\
5.3\end{array}$ & $\begin{array}{r}1,201,780 \\
3.0\end{array}$ & $\begin{array}{r}-920,030 \\
-2.4\end{array}$ & -43.4 \\
\hline Claimant Count & $1,515,850$ & 903,920 & $-611,930$ & -40.4 \\
\hline & 3.8 & 2.2 & -1.6 & \\
\hline
\end{tabular}

NB: ILO unemployment is for annual file April 2012-March 2013

Sources: DWP, ONS

The impact of the full roll out of UC in Rotherham (mid-July 2017) is only just beginning to be seen in the later stages of the time series (Figure 4.2). After a period of stability, the Claimant Count began to rise after July 2018 as the number of people expected to search for work increased as wider groups of claimants began to be affected by conditionality. Between July 2018 and December 2018 the Claimant Count rose by 435 people from 2.6 to 3.0 per cent of working age people. Potentially, this may eventually impact on the number of people who are also recorded as economically active. 
Figure 4.2: Unemployed claimants in Rotherham, 2013

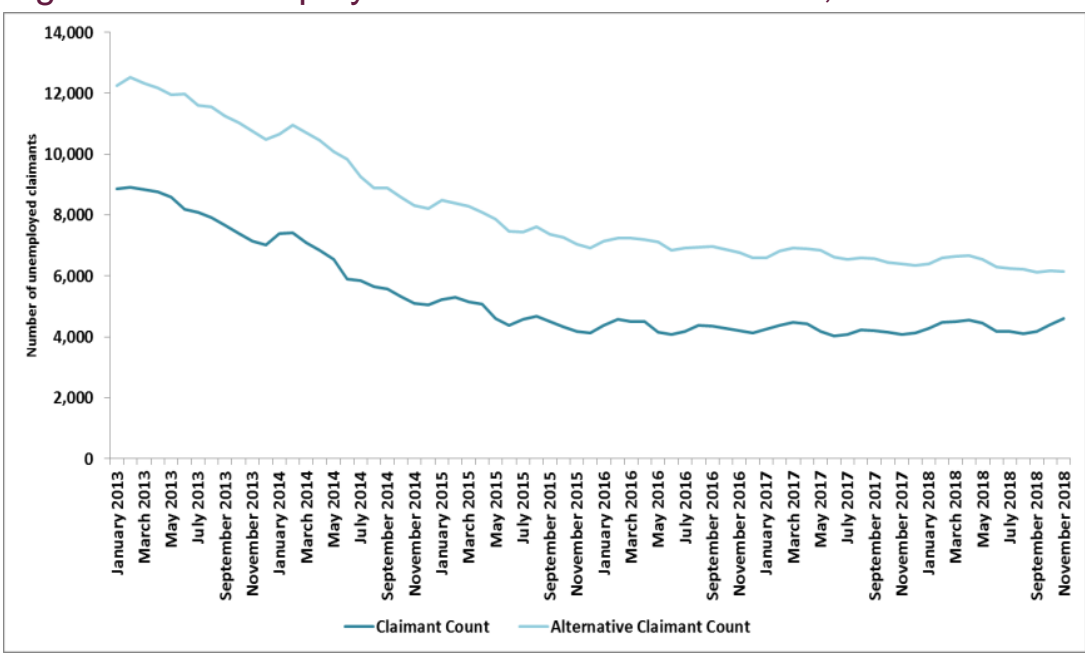

Sources: DWP, ONS

The Alternative Claimant Count comprises of three groups. JSA claimants, UC claimants searching for work and 'additionals' (Table 4.2). Given that Rotherham has only recently moved over to the full service UC a higher proportion of claimants are still within the JSA system (30 per cent) than is seen nationally ( 26 per cent).

Table 4.2: Alternative Claimant Count, November 2018

\begin{tabular}{lcccccc}
\hline & \multicolumn{2}{c}{ Rotherham } & & \multicolumn{2}{c}{ Great Britain } \\
\cline { 2 - 3 } \cline { 5 - 6 } & Number & $\begin{array}{c}\text { Percentage } \\
\text { of total }\end{array}$ & & Number & $\begin{array}{c}\text { Percentage } \\
\text { of total }\end{array}$ \\
\hline $\begin{array}{l}\text { Jobseeker's Allowance } \\
\text { Universal Credit }\end{array}$ & 1,870 & 30 & & 316,130 & 26 \\
$\begin{array}{l}\text { Searching for Work } \\
\text { Additionals }\end{array}$ & 2,310 & 38 & & 517,440 & 43 \\
Total & 1,980 & 32 & & 365,610 & 30 \\
\hline
\end{tabular}

Sources: DWP

A third of the DWP Alternative Claimant Count is a group classified as 'additionals'. These are people who would not have been not subject to sanctioning under the old JSA system if they didn't look for work, but would be under the Universal Credit system. The 'additionals' include:

- People in working families who claimed in-work Housing Benefit but were not in work themselves.

- Parents who are low-paid but aren't the main carer.

- Carers where the person cared for has not proved beyond reasonable doubt to DWP (through the PIP benefit test) that personal care is required. 


\section{Characteristics of unemployed claimants}

The LFS data asks respondents about their benefits status job search activities, aspirations to work and barriers to work. The sample sizes are too small to consider claimant groups for Rotherham but national level data provides a good indication of the likely characteristics of claimants. The July-September 2015 LFS data (before the roll out of full service UC) indicates that JSA claimants aged 18-64 in Britain are:

- More likely to live in the social rented sector (SRS) compared to the age group as a whole (55 per cent and 16 per cent respectively);

- Just over one in five live in the private rented sector; 21 per cent compared to 19 per cent of all 18-64 year olds;

- The main method of job search for claimants was to look at situations vacant columns in newspapers etc (41 per cent) and via the Job Centre (16 per cent); however, 19 per cent had not looked in the last four weeks.

Nationally, nearly one in five JSA claimants aged 18-64 can be considered as economically inactive given that they were either not seeking or available for work. These fall into three groups: actively seeking work but unavailable (4 per cent); not seeking for work but would like work (6 per cent) or not seeking work and would not like work (9 per cent).

For those JSA claimants not seeking work, nearly half said this was because they were longterm sick or disabled and over a quarter said it was because they were looking after a family. This gives clear insights as to potential extra support which may be required for some JSA claimants to help get them back into work: improving health and access to affordable childcare.

If this pattern was replicated within the JSA claimants in Rotherham then approximately 150 JSA claimants may not be looking for work due to long-term sickness or disablement and a further 75 claimants due to caring responsibilities. If these characteristics are seen amongst the wider Alternative Claimant Count then these figures would rise to 450 and 230 respectively.

\section{Poor health as a barrier to work for unemployed claimants}

Long-term ill health and disability is common place amongst JSA claimants nationally and this is likely to be the case for equivalent group amongst UC claimants looking for work. Nearly half have a health problem lasting over a year and this is double the rate seen amongst those in employment (Table 4.3). Long-term health problems are even more prevalent amongst those who have been JSA claimants for over a year (56 per cent) and is even more extensive amongst JSA claimants aged over 50 years old (70 per cent).

The LFS also gives us insights as to the type of long-term health problems claimants report. The most prevalent main health problem for JSA claimants is depression/bad nerves with 11 per cent of all claimants saying this is their main long-term health problem. This is more than five times the rate seen amongst those in employment and for this group the most common main health problem is chest or breathing problems (three per cent of all employed). 
Table 4.3: JSA claimants with health problems lasting more than a year, aged 18-64, Great Britain, July - September 2015

\begin{tabular}{|c|c|c|c|c|c|}
\hline & \multirow[b]{2}{*}{$\begin{array}{l}\text { Per cent of } \\
\text { employed }\end{array}$} & \multicolumn{4}{|c|}{ Per cent of JSA claimants } \\
\hline & & All & $\begin{array}{l}\text { Duration } \\
1+\text { years } \\
\end{array}$ & $\begin{array}{l}\text { Aged } \\
18-24 \\
\end{array}$ & $\begin{array}{c}\text { Aged } \\
50+\end{array}$ \\
\hline \multicolumn{6}{|l|}{ Health problem lasting over a year: } \\
\hline all with a health problem over a year & 24 & 48 & 56 & 29 & 70 \\
\hline which affects kind of work can & 8 & 33 & 42 & 18 & 52 \\
\hline which affects amount work can do & 6 & 28 & 33 & 17 & 45 \\
\hline \multicolumn{6}{|l|}{ Main health problem lasting over a year: } \\
\hline $\begin{array}{l}\text { Depression, bad nerves } \\
\text { Mental illness, phobia, panics, nervous }\end{array}$ & 2 & 11 & 12 & 9 & 9 \\
\hline disorders & - & 2 & 3 & 3 & - \\
\hline Severe or specific learning difficulties & - & 1 & 1 & - & 1 \\
\hline \multicolumn{6}{|l|}{ Any health problems lasting over a year } \\
\hline Depression, bad nerves & 4 & 20 & 21 & 14 & 25 \\
\hline $\begin{array}{l}\text { Mental illness, phobia, panics, nervous } \\
\text { disorders }\end{array}$ & 1 & 7 & 8 & 5 & 5 \\
\hline Severe or specific learning difficulties & 1 & 4 & 4 & 4 & 2 \\
\hline
\end{tabular}

Respondents could state more than one long-term health problem if they had one and when all health problems are considered, not just the main one, the proportion of JSA claimants stating depression or bad nerves rises to one in five claimants compared to just one in twenty five people in employment.

\section{Skills and qualifications as a barrier to work for JSA claimants}

Table 4.4 shows clearly that unemployed benefit claimants are far more likely than the employed to have no formal qualifications: one in five compared to one in twenty. This lack of qualifications rises to one in four of JSA claimants who are long-term unemployed. JSA claimants are also far less likely to have a degree or qualification gained from higher education than those in employment: 17 per cent compared to 43 per cent.

Whilst no variables are available on basic literacy and numeracy levels, the LFS does ask respondents about their use of the internet. The vast majority of those in work and on JSA have used the internet in the last three months. However, it is noticeable that eight per cent of JSA claimants have not, rising to 10 per cent of the long-term unemployed and 14 per cent of claimants aged over 50 (of whom 12 per cent said they had never used the internet).

JSA claimants' previous employment is also far more likely to have been in a low skill job than the occupation structure ${ }^{12}$ of those in employment. Some 45 per cent of those in employment are in high skill jobs whereas only 13 per cent of JSA claimants were previously in a high skill job, falling to six per cent amongst the long-term unemployed. Conversely, compared to 28 per cent of people in employment working in a low skill job, for JSA

\footnotetext{
${ }^{12}$ The groupings are based on the allocation SOC codes on the same basis as the ILO allocation of ISCO categories to high, medium and low skill jobs. High skill incudes SOC1-3: Managers, Directors, Senior Officials/Professional Occupations/Associate professional and technical; Medium Skill includes SOC4,5,8: Admin/skilled trade/process and plant operatives and Low Skill includes SOC 6,7,9: Caring, Leisure, other services/Sales and Customer Services/Elementary occupations.
} 
claimants the comparable figure for their previous job is 58 per cent, rising 64 per cent of the long-term unemployed and 78 per cent of JSA claimants aged under 25.

Table 4.4: Skills and qualifications of JSA claimants aged 18-64, Great Britain, July September 2015

\begin{tabular}{|c|c|c|c|c|c|}
\hline & \multirow[b]{2}{*}{$\begin{array}{l}\text { Per cent of } \\
\text { employed }\end{array}$} & \multicolumn{4}{|c|}{ Per cent of JSA claimants } \\
\hline & & All & $\begin{array}{l}\text { Duration } \\
1+\text { years }\end{array}$ & $\begin{array}{l}\text { Aged } \\
18-24\end{array}$ & $\begin{array}{c}\text { Aged } \\
50+\end{array}$ \\
\hline \multicolumn{6}{|l|}{ Highest qualification } \\
\hline Degree or higher education & 43 & 17 & 10 & 10 & 18 \\
\hline GCE A level or equivalent & 23 & 17 & 15 & 22 & 17 \\
\hline GCSE grades $A^{*}-C$ or equivalent & 19 & 29 & 26 & 38 & 25 \\
\hline Other qualification & 8 & 17 & 22 & 16 & 18 \\
\hline No qualification & 5 & 19 & 25 & 12 & 22 \\
\hline Don't know & 1 & 1 & 1 & 3 & 0 \\
\hline Total & 100 & 100 & 100 & 100 & 100 \\
\hline \multicolumn{6}{|l|}{ Internet skills } \\
\hline Used the internet within the last 3 months & 98 & 92 & 90 & 97 & 86 \\
\hline Used the internet but not within last 3 months & 1 & 3 & 3 & 3 & 2 \\
\hline Never used the internet & 1 & 5 & 7 & 0 & 12 \\
\hline Total & 100 & 100 & 100 & 100 & 100 \\
\hline \multicolumn{6}{|l|}{ Skill level of current/last job } \\
\hline High skill & 45 & 13 & 6 & 3 & 25 \\
\hline Middle skill & 28 & 29 & 31 & 19 & 29 \\
\hline Low skill & 28 & 58 & 64 & 78 & 46 \\
\hline Total & 100 & 100 & 100 & 100 & 100 \\
\hline
\end{tabular}

Source: LFS

JSA claimants may face other barriers to work including having English as their second language (ESOL). Again sample sizes meant it was not possible to look specifically at residents in Rotherham but the characteristics of unemployed claimants in Britain within the LFS are used as a proxy.

Table 4.5 shows a similar proportion of ESOL amongst JSA claimants in Britain as those in employment. However, language difficulties amongst the ESOL employed group are far less of an issue than for the claimant unemployed. Just 8 per cent of the ESOL employed group have language difficulties in education and 14 per cent find this causes them problems in finding or keeping a job. These figures rise to more than one in five JSA ESOL claimants in respect to causing problems in education and over a third when it comes to causing problems in finding or keeping a job.

Overall, JSA claimants face significant and multiple disadvantage in the workforce. Their lack of qualifications, skills, poor health and caring responsibilities are all likely to make it more difficult for them to compete for available jobs. These issues are likely to be even more entrenched the longer they are unemployed. 
Table 4.5: English as a second language, JSA claimants aged 18-64, Great Britain, July September 2015

\begin{tabular}{crc}
\hline & \multicolumn{2}{c}{ Per cent of } \\
\cline { 2 - 3 } English as a second language (ESOL) & $\begin{array}{c}\text { JSA } \\
\text { claimants }\end{array}$ \\
\hline Percentage of ESOL & 10 & 10 \\
$\quad$ Language difficulties cause problems in education? & 8 & 22 \\
Language difficulties cause problems in finding or keeping a job? & 14 & 36 \\
\hline
\end{tabular}

Source: LFS 


\section{Economic inactivity in Rotherham}

\section{Introduction}

Chapter 3 indicates that the economic activity rate in Rotherham over time has lagged behind the national rate. The economic activity rate has been improving since 2017 and the 3 year average for 2016-2018 is 76.3 per cent compared to the national rate over this period of 78.1 per cent. If the last three annual APS data files in 2018 from NOMIS ${ }^{13}$ for Rotherham are considered then all are indicate the local economic activity rate is above 79 per cent (average 79.4 per cent). This compares to an average of 78.4 for Britain over the same three data points. The figures for Rotherham do need to be treated with some degree of caution as there is a greater degree of sampling variability if any one time peiod is used ${ }^{14}$ and the annual files will have overlapping quarterly samples underpinning them. Time will tell if this upward trend seen in Rotherham is consolidated over time. If the trend holds then the economic activity rate in Rotherham may now have surpassed the national average.

It is also important to understand the characteristics of the economically inactive as well as the unemployed. Some residents maybe economically inactive through choice - perhaps to look after a family or be a full-time student - but for others it may not be through choice but because they face barriers to actively participating in the labour force. These residents may benefit from further opportunities and support to enhance their skills and qualifiactions inorder to make them more competitive in the workforce.

The analysis below is taken from secure access APS pooled data for three years from 20152017. The data file covers all English local authorities and so this is used as a benchmark rather than Great Britain. It can be seen that economic activity rates for Rotherham and England for 2015-2017 are both in line with the figures from the 2016-2018 above.

\section{Reasons for economic inactivity}

Table 5.1 provides a breakdown of the reasons why working age people in Rotherham are economically inactive. The vast majority of economically inactive people of working age are not seeking work (23 per cent). This is only slightly higher than seen nationally (21 per cent).

\footnotetext{
${ }^{13}$ Apr 2017-Mar 2018, Jul 2017-Jun 2018, Oct 2017-Sep 2018

${ }^{14}$ For Rotherham +/- 2.7 percentage points; for GB +/- 0.2 percentage points
} 


\begin{tabular}{|c|c|c|c|c|c|}
\hline & & Rotherham & SCR & Y\&H & England \\
\hline \multirow{4}{*}{ 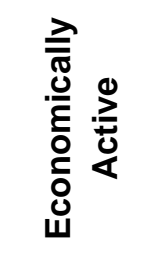 } & Employee & 63 & 62 & 64 & 64 \\
\hline & Self-employed & 10 & 9 & 9 & 11 \\
\hline & ILO Unemployed & 4 & 5 & 4 & 4 \\
\hline & Economically active: Total & 76 & 76 & 77 & 78 \\
\hline \multirow{10}{*}{ 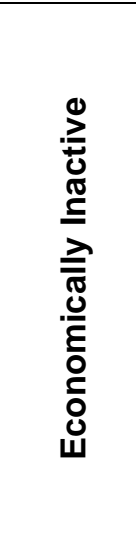 } & Seeking employment & 1 & 1 & 1 & 1 \\
\hline & Not seeking employment & 23 & 23 & 22 & 21 \\
\hline & Not seeking - student & 3 & 7 & 6 & 6 \\
\hline & Not seeking - looking after home or family & 6 & 6 & 6 & 5 \\
\hline & Not seeking - temporary sick/injured & 1 & 0 & 0 & 0 \\
\hline & Not seeking - long-term sick or disabled & 6 & 6 & 5 & 5 \\
\hline & Not seeking - does need a job & 1 & 1 & 1 & 1 \\
\hline & Not seeking - retired & 3 & 3 & 3 & 3 \\
\hline & Not seeking - other reason & 3 & 2 & 1 & 2 \\
\hline & Economically Inactive: total & 24 & 24 & 23 & 22 \\
\hline Total & & 100 & 100 & 100 & 100 \\
\hline Total $\mathbf{N}$ & & 159,000 & 719,400 & $3,374,100$ & $34,518,100$ \\
\hline
\end{tabular}

Source: Annual Population Survey

The two most common reasons for being ecomomically inactive in Rotherham are looking after a home or family ( 6 per cent of working age people) or being long-term sick or disabled (6 per cent). There are fewer students in Rotherham than the wider benchmarks but this would be expected due to not being a Univesity town.

At first glance, the figures for working age Rotherham residents as a whole on these measures are in line with the wider city region and national benchmarks. Table 5.2 dissaggregates the data further by age. There are very similar patterns of economic activity and inactivity amongst the majority the 25-49 year olds in Rotherham as seen in the other benchmark areas. This age group accounts for just over half the entire working age population. There are subtle differences between Rotherham and the other areas for the younger and older age groups which are summarised here.

\section{Young people age 16 to 24 years old}

- 16-24 years old residents in Rotherham have a higher economic activity rate than the regional benchmark areas and nationally; 66 per cent, 62 per cent and 61 per cent respectively.

- This translates into higher employment rates for this age group in Rotherham than nationally; 57 per cent and 53 per cent respectively.

- A lower proportion of 16-24 year olds are economically inactive than nationally; 34 per cent compared to 39 per cent.

- $\quad$ Treble the national rate of 16-24 year olds are long term-sick or disabled in Rotherham; 6 per cent compared to 2 per cent. 
Table 5.2: Economic inactivity in Rotherham by age, 16-64 year olds, 2015-2017

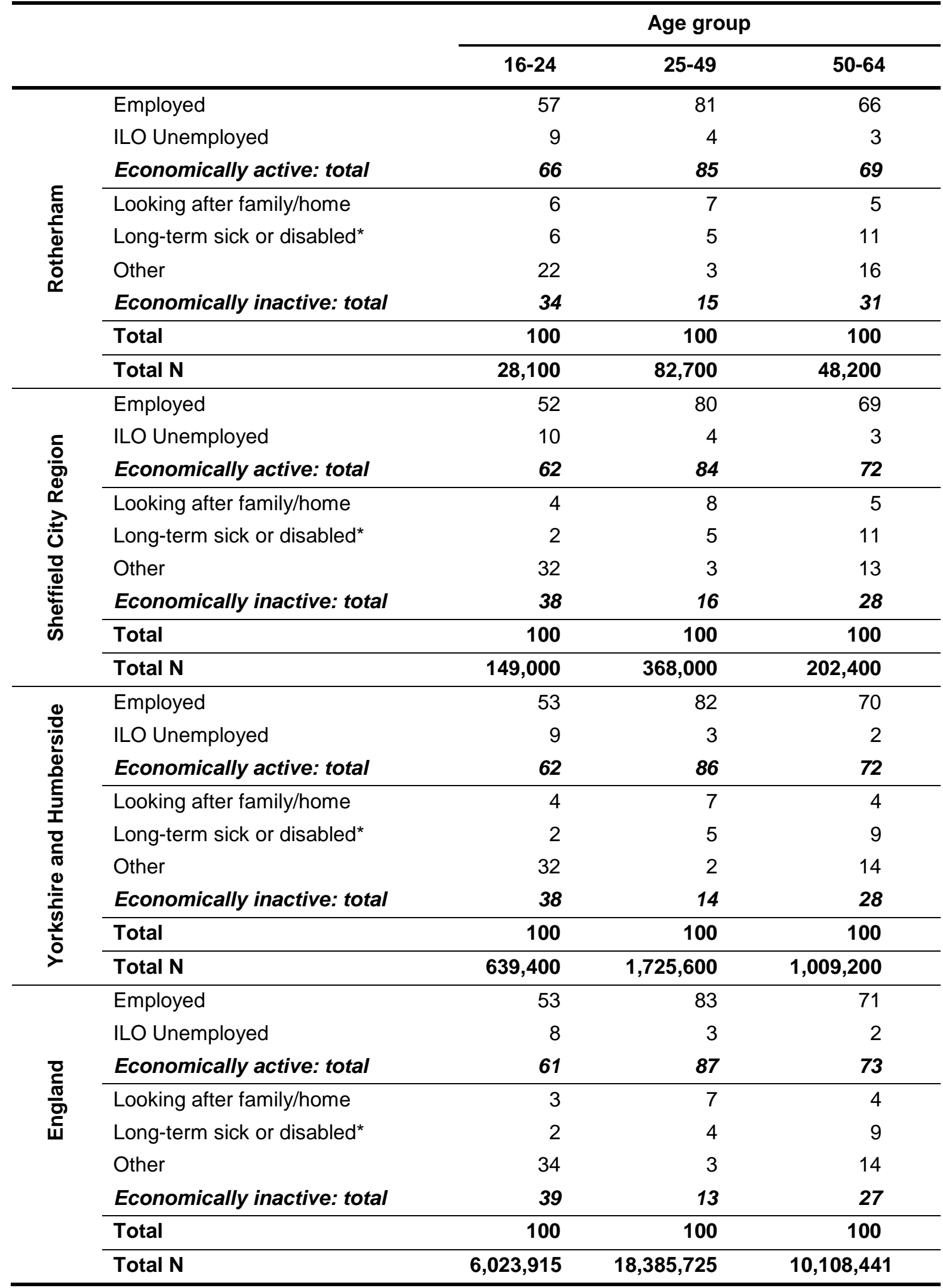

*includes small number of people in the temporary sick or injured category

Source: Annual Population Survey

- Double the national rate of 16-24 year olds in Rotherham stay at home to look after a home or a family; 6 per cent compared to 3 per cent; these are predominantly women. 
- Those classified as 'other' economically inactive is much lower in Rotherham (22 per cent) compared to nationally (34 per cent); this catch all 'other' group in this table includes students.

In Rotherham, 20 per cent of all economically inactive 16-24 year olds are students. This is lower than seen in SCR, and Yorkshire and Humberside (both 29 per cent), and England (31 per cent). This difference may in part reflect the higher number of students in University cities in the wider region. However, it may also reflect education and training routes for 1618 year olds. Chapter 6 explores apprenticeship data and NEETS data further to explore this issue.

\section{Older people aged 50-64 years old}

- 50-64 years old residents in Rotherham have a lower economic activity rate than the regional benchmark areas and nationally; 69 per cent, 72 per cent and 73 per cent respectively.

- This translates into lower employment rates for this age group in Rotherham than nationally; 66 per cent and 71 per cent respectively.

- A higher proportion of 50-64 year olds are economically inactive than nationally; 31 per cent compared to 27 per cent.

- A slightly higher proportion of 50-64 year olds are long-term sick or disabled in Rotherham than nationally; 11 per cent compared to 9 per cent.

- Early retirees account for a similar proportion of economically inactive 50-64 year olds in all areas - between 10 per cent (England and SCR) and 11 per cent (Rotherham, and Yorkshire and Humberside).

\section{Economic inactivity by gender}

Table 5.3 explores differences in labour market participation by gender. Economic activity rates amongst men in Rotherham are in line with the national picture with both at 83 per cent of the male working age population. There are some differences in the reasons for economic inactivity amongst men compared to the national picture. There are fewer students and more men are classified as long-term sick or disabled (8 per cent compared to 5 per cent nationally). The trend in claimants on long-term incapacity benefits are also considered later in this chapter.

The rate of labour market participation amongst women (70 per cent) is a little lower than the national average (73 per cent) or the region (72 per cent). This is explained by a slightly higher proportion of women in Rotherham staying at home to look after a family or home (12 per cent comapred to 10 per cent nationally) and slightly more women in the 'other' inactive category (16 per cent in Rotherham compared to 13 per cent nationally). It is not possible to break down this group further at the level of the local authority but this group includes people who may be early retirees, those who do not need a job or are classified as 'other', for example, they may a full-time carer for another relative. 
Table 5.3: Economic inactivity Rotherham residents by reason, 16-64 year olds, 2015-2017

\begin{tabular}{|c|c|c|c|c|c|c|c|c|}
\hline & \multicolumn{2}{|c|}{ Rotherham } & \multicolumn{2}{|c|}{ SCR } & \multicolumn{2}{|c|}{ Y\&H } & \multicolumn{2}{|c|}{ England } \\
\hline & Male & Female & Male & Female & Male & Female & Male & Female \\
\hline Employee & 64 & 61 & 62 & 62 & 64 & 63 & 65 & 62 \\
\hline Self-employed & 14 & 5 & 13 & 5 & 13 & 6 & 14 & 7 \\
\hline ILO Unemployed & 5 & 3 & 5 & 4 & 5 & 4 & 4 & 3 \\
\hline Economically active: total & 83 & 70 & 80 & 71 & 82 & 72 & 83 & 73 \\
\hline Student & 3 & 4 & 8 & 6 & 6 & 6 & 6 & 6 \\
\hline Looking after home or family & $\mathrm{N} / \mathrm{A}$ & 12 & $\mathrm{~N} / \mathrm{A}$ & 11 & $N / A$ & 10 & $\mathrm{~N} / \mathrm{A}$ & 10 \\
\hline Long-term sick or disabled* & 8 & 6 & 6 & 6 & 6 & 5 & 5 & 5 \\
\hline Retired & 3 & 4 & 2 & 3 & 3 & 4 & 2 & 4 \\
\hline Other & 3 & 16 & 3 & 14 & 3 & 13 & 3 & 13 \\
\hline Economically inactive total & 17 & 30 & 20 & 29 & 18 & 28 & 17 & 27 \\
\hline Total & 100 & 100 & 100 & 100 & 100 & 100 & 100 & 100 \\
\hline Total N & 79,700 & 79,300 & 361,000 & 358,400 & $1,681,600$ & $1,692,500$ & $17,175,500$ & $1,7342,500$ \\
\hline
\end{tabular}

Source: Annual Population Survey

* includes small number of people in the temporary sick or injured category 
Table 5.4 presents the differences in the composition of the economically inactive group in Rotherham relative to the benchmarks by expressing each reason for inactivity as a percentage of the economically inactive as a whole. The table highlights the lower proportion of students in Rotherham compared to nationally; the higher proportion of men who are inactive due to ill health; and the slightly high proportion of women who are looking after a home or family.

Table 5.4: Reasons for economic inactivity, Rotherham, economically inactive 16-64 year olds, 2015-2017

\begin{tabular}{|c|c|c|c|}
\hline & Rotherham & $\begin{array}{r}\text { Combined } \\
\text { Authority }\end{array}$ & England \\
\hline \multicolumn{4}{|c|}{ All economically inactive $16-64$ year olds } \\
\hline Students & 17 & 23 & 27 \\
\hline Looking after family/home & 28 & 26 & 26 \\
\hline Long-term sick or disabled* & 30 & 29 & 23 \\
\hline Retired & 13 & 12 & 13 \\
\hline Other & 13 & 10 & 11 \\
\hline Total & 100 & 100 & 100 \\
\hline \multicolumn{4}{|c|}{ Economically inactive16-64 year old males } \\
\hline Students & 23 & 32 & 36 \\
\hline Long-term sick or disabled* & 42 & 38 & 30 \\
\hline Retired & 15 & 13 & 14 \\
\hline Other** & 21 & 16 & 20 \\
\hline Total & 100 & 100 & 100 \\
\hline \multicolumn{4}{|c|}{ Economically inactive16-64 year old females } \\
\hline Students & 13 & 17 & 21 \\
\hline Looking after family/home & 41 & 39 & 37 \\
\hline Long-term sick or disabled* & 23 & 23 & 19 \\
\hline Retired & 11 & 11 & 13 \\
\hline Other & 12 & 10 & 10 \\
\hline Total & 100 & 100 & 100 \\
\hline
\end{tabular}

\section{Economic inactivity for ethnic minority groups}

Whilst the 2011 Census shows that the non-white population in Rotherham is relatively small compared to England as a whole (6 per cent versus 15 per cent) it is worth considering the extent to which some ethnic groups may be more marginalised in the workforce than others. The biggest BAME community in Rotherham are Asian; 4 per cent compared to 8 per cent nationally. However, there are some notable differences in the composition of this group locally compared to nationally which need to be borne in mind when interpreting the data.

In 2011, nearly three quarters (72 per cent) of the Asian population in Rotherham are of Pakistani heritage, a further 1 per cent are Bangladeshi and 9 per cent are Indian. In England as a whole, the ethnic mix within the Asian community is very different with only 
approximately one in four being Pakistani (27 per cent), 11 per cent are Bangladeshi and 34 per cent are Indian. The population composition in the CA and SCR are somewhere in between with just over half of the Asian community being either Pakistani or Bangladeshi with (56 per cent and 54 per cent respectively), and approximately one in six of Indian origin (14 per cent and 16 per cent respectively).

These differences in population composition are important to understand when interpreting local economic activity data against benchmarks by summary categories such as 'Asian' or ethnic minorities as a whole. This is because there are notable differences in economic activity patterns within as well as between ethnic groups. For example, the three year average of APS data from 2015-2017 shows that 20 per cent of whites aged 16-64 are economically inactive compared to 30 per cent of ethnic minority 16-64 year olds (Table 5.5). But, whereas economic inactivity rates amongst Indians are very similar whites (23 per cent versus 20 per cent), the economic inactivity rate for working age residents of Pakistani or Bangladeshi origin is much higher at 39 per cent. These differences are also reflected in national employment rates by ethnic groups.

The composition of the Rotherham population therefore means that there is likely to be a gap between local summary data for ethnic minorities as a whole and the regional or national benchmarks, even when all other things are equal. If possible, it is therefore more appropriate to consider the differences in the economic activity patterns for the white and Pakistani/Bangladeshi populations for Rotherham versus benchmark areas.

Table 5.5: Economic inactivity and employment rates by ethnic groups, England, 16-64 year olds, 2015-2017

\begin{tabular}{lcc}
\hline & \multicolumn{2}{c}{ Percentage of 16-64 year olds } \\
\cline { 2 - 3 } & Economically inactive & Employed \\
\hline White & 20 & 76 \\
Ethnic minority & 30 & 64 \\
Indian & 23 & 73 \\
Pakistani/Bangladeshi & 39 & 54 \\
All & $\mathbf{2 2}$ & $\mathbf{7 4}$ \\
\hline
\end{tabular}

Source: Annual Population Survey

Table 5.6 gives details of economic inactivity for main ethnic groups and gender in both Rotherham and England. Given the uneven nature of labour market growth and demand for labour across the regions it is to be expected that employment and economic activity rates in Rotherham will be lower than the national average. The England benchmark contains the South East, East and South West regions many parts of which have been operating at fullemployment for some time. This has the effect of raising both employment and economic activity rates for England as a whole. However, there are some important differences in economic inactivity rates for 16-64 year olds that are worth note: 
Table 5.6: Economic inactivity and employment rates by ethnic groups, Rotherham, 16-64 year olds, 2015-2017

\begin{tabular}{|c|c|c|c|c|c|c|}
\hline & \multicolumn{3}{|c|}{ Rotherham } & \multicolumn{3}{|c|}{ England } \\
\hline & White & $\begin{array}{l}\text { Ethnic } \\
\text { minority }\end{array}$ & $\begin{array}{l}\text { Pakistani/ } \\
\text { Bangladeshi }\end{array}$ & White & $\begin{array}{l}\text { Ethnic } \\
\text { minority }\end{array}$ & $\begin{array}{l}\text { Pakistani// } \\
\text { Bangladeshi }\end{array}$ \\
\hline \multicolumn{7}{|l|}{ All 16-64 year olds } \\
\hline Economically Active & 77 & 62 & 55 & 80 & 70 & 61 \\
\hline In employment & 72 & 58 & 53 & 76 & 64 & 54 \\
\hline ILO Unemployed & 5 & 4 & 2 & 3 & 6 & 7 \\
\hline Economically Inactive & 23 & 38 & 45 & 20 & 30 & 39 \\
\hline \multicolumn{7}{|l|}{ Males aged 16-64 } \\
\hline Economically Active & 83 & 77 & 69 & 84 & 79 & 78 \\
\hline In employment & 77 & 72 & 68 & 81 & 73 & 71 \\
\hline ILO Unemployed & 5 & 5 & 2 & 4 & 6 & 7 \\
\hline Economically Inactive & 17 & 23 & 31 & 16 & 21 & 22 \\
\hline \multicolumn{7}{|l|}{ Females aged 16-64 } \\
\hline Economically Active & 71 & 43 & 38 & 75 & 61 & 42 \\
\hline In employment & 67 & 41 & 34 & 72 & 56 & 36 \\
\hline ILO Unemployed & 4 & 2 & 3 & 3 & 6 & 6 \\
\hline Economically Inactive & 29 & 58 & 62 & 25 & 39 & 58 \\
\hline
\end{tabular}

Source: Annual Population Survey

- Rotherham economic inactivity rates are only slightly higher than the national average (24 per cent and 22 per cent respectively, Table 5.1).

- The gap is slightly wider amongst the white population; 23 per cent in Rotherham and 20 per cent in England.

- Economic inactivity rates amongst the Pakistani/Bangladeshi population in England are almost double those for whites (39 per cent compared to 20 per cent) and a similar ratio is seen in Rotherham (45 per cent compared to 23 per cent.

- The Pakistani/Bangladeshi economic inactivity rate in Rotherham is six percentage points higher than nationally.

- The economic inactivity rate of white men in Rotherham is similar to that seen nationally (17 per cent versus 16 per cent).

- Amongst Pakistani/Bangladeshi men there is a more notable difference in economic inactivity rates; 31 per cent in Rotherham compared to 22 per cent in England.

Traditionally, women have had higher economic inactivity rates than men often due to childcare responsibilities. Economic activity rates have steadily increased for women since the 1980s as more women continue to work whilst having small children or return to work after a period out of the labour market to raise children. In England, 27 per cent of working age women are economically inactive some 10 percentage point higher than men of the same age. In Rotherham, this figure rises to 30 per cent whereas the figure for men remains on a par with the national figure of 17 per cent. 
One part of the explanation for this may be the ethnic composition of the working age population as patterns of economic activity differ significantly by ethnic groups. For some groups there are more traditional expectations for women to stay at home when they have children and this is the normative family behaviour. For others, larger family sizes may mean that childcare costs outweigh the income that can be earned and so this may also contribute to economic inactivity. Table 5.6 shows that for working age women:

- In Rotherham, 62 per cent of Pakistani/Bangladeshi women are economically inactive, four percentage points higher than in England (58 per cent).

- The economic inactivity rate of white women in Rotherham is also four percentage points higher than in England; 29 per cent and 25 per cent respectively.

- The employment rate for Rotherham Pakistani/Bangladeshi women who participate in the workforce is very similar to that seen nationally; 34 per cent and 36 per cent respectively.

- As with white men, the employment rate for white women in Rotherham lags behind the comparable group in England by a greater extent than the gap seen for Pakistani/Bangladeshi women; the employment rate for white women in Rotherham is 67 per cent compared to 72 per cent in England.

Table 5.7: Economically inactive who want a job, Rotherham, 16-64 year olds, 2015-2017

\begin{tabular}{|c|c|c|c|}
\hline & Rotherham & $\begin{array}{l}\text { Combined } \\
\text { Authority }\end{array}$ & England \\
\hline \multicolumn{4}{|c|}{ All economically inactive aged $16-64$} \\
\hline Who want a job & 26 & 27 & 24 \\
\hline Who do not want a job & 74 & 73 & 76 \\
\hline \multicolumn{4}{|c|}{ All economically inactive males aged $16-64$} \\
\hline Who want a job & 30 & 28 & 26 \\
\hline Who do not want a job & 69 & 72 & 74 \\
\hline \multicolumn{4}{|c|}{ All economically inactive females aged $16-64$} \\
\hline Who want a job & 23 & 26 & 22 \\
\hline Who do not want a job & 77 & 74 & 78 \\
\hline
\end{tabular}

Source: Annual Population Survey

Table 5.7 explores the extent to which economically inactive working age people in Rotherham are not participating in the workforce through choice because they do not want a job. The differences across areas are relatively subtle as the vast majority of economically inactive people across all areas and sub-groups of the population do not want a job. In Rotherham 26 per cent would like a job and this is only slightly higher than the national figure of 24 per cent. This rises to 30 per cent of males and the gap with the national picture also increases to 4 percentage points. For women the difference between Rotherham and the national benchmark is negligible; 23 per cent and 22 per cent respectively. Unfortunately it is not possible to run this analysis split by gender and ethnicity given the small sample sizes involved. 


\section{Economic inactivity due to long-term sickness or disability}

Six per cent of all working age people in Rotherham are economically inactive because of long-term sickness or disability, slightly higher than the national rate of five per cent. This compares to four per cent of working age people being ILO unemployed in both Rotherham and England (Table 5.1). There were 4,180 people claiming unemployment-related benefits (JSA or UC search for work) in Rotherham at September 2018 equivalent to 2.6 per cent of working age population or a national rate of 2.2 per cent (see Table 4.1 earlier).

People claiming out-of-work benefits for reasons of ill-health are far more numerous. In Britain 2,357,000 working age people claimed incapacity benefits ${ }^{15}$ in May 2018 equivalent to 5.8 per cent of the working age population. This compares with a rate of 7.9 per cent in Rotherham at the same point of time or 12,750 people. Even through the incapacity benefits rate has been declining in recent years (Figure 5.1) it is still substantially higher than the local unemployment rate. This poses a significant challenge for Rotherham and many other older industrial towns in northern Britain if both economic activity rates and employment rates are to be improved further.

Figure 5.1: Incapacity benefits claimant rate, 16-64 year olds, Rotherham, 2010-2018

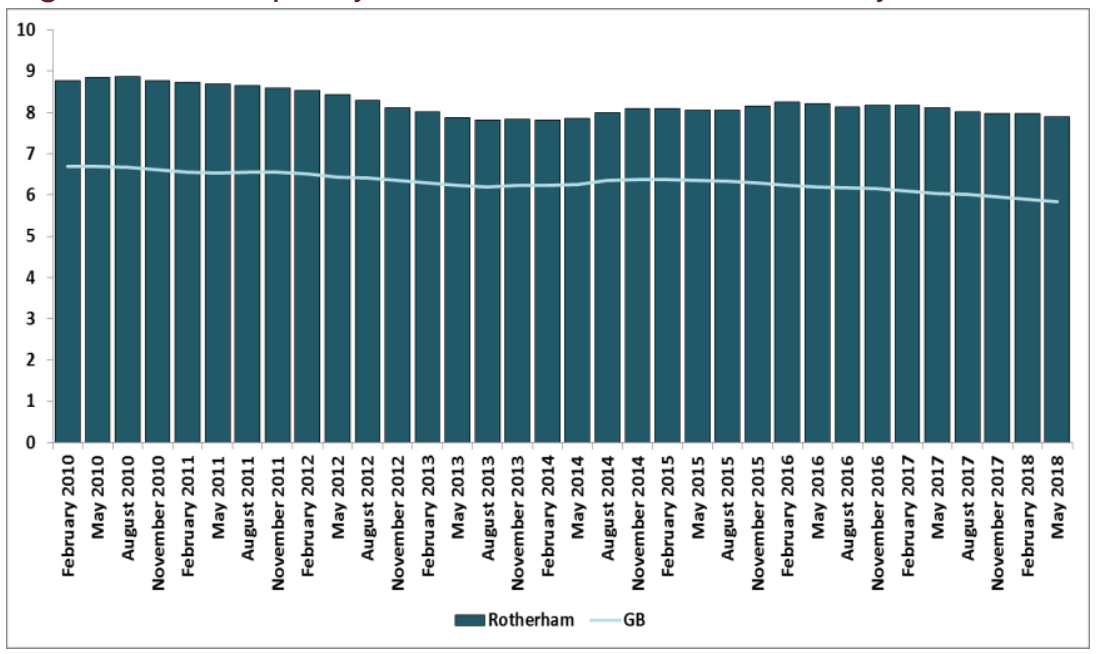

Source: DWP

\section{Skills and qualifications as a barrier to work for ESA claimants}

III health and disability, although a substantial problem, is not the only barrier that incapacity benefits claimants face as significant employability issues exist amongst the group. It is not possible to run the following table for Rotherham claimants due to sample sizes, but the likelihood is that the characteristics of claimants in Britain are transferable to the nature of claimants in local areas.

Table 5.8 shows clearly that ESA claimants in Britain are more likely to have poor skills or qualifications relative to other groups. Over a quarter of ESA claimants have no formal qualifications compared to one in five JSA claimants and one in twenty of those in employment. ESA claimants who are closer to the labour market (either those looking for or

\footnotetext{
${ }^{15}$ Incapacity benefits include individuals claiming Employment and Support Allowance, Incapacity Benefit or Severe Disablement Allowance, and households with at least one individual claiming Universal Credit Limited Capability to Work.
} 
available for work or with a duration under one year) are more similar to the profile seen amongst JSA claimants.

Table 5.8: Skills and qualifications of JSA claimants aged 18-64, Great Britain, July September 2015

\begin{tabular}{|c|c|c|c|c|c|}
\hline & \multirow[b]{2}{*}{$\begin{array}{c}\text { Per cent of } \\
\text { JSA } \\
\text { claimants }\end{array}$} & \multicolumn{4}{|c|}{ Per cent of ESA claimants } \\
\hline & & All & $\begin{array}{l}\text { Not with } \\
\text { DLA }\end{array}$ & $\begin{array}{c}\text { Duration } \\
<1 \text { year }\end{array}$ & $\begin{array}{c}\text { Looking } \\
\text { or } \\
\text { available } \\
\text { for work }\end{array}$ \\
\hline \multicolumn{6}{|l|}{ Highest qualification } \\
\hline Degree or higher education & 17 & 15 & 14 & 17 & 19 \\
\hline GCE A level or equivalent & 17 & 17 & 18 & 25 & 21 \\
\hline GCSE grades $A^{*}-C$ or equivalent & 29 & 25 & 27 & 35 & 29 \\
\hline Other qualification & 17 & 14 & 14 & 9 & 14 \\
\hline No qualification & 19 & 27 & 26 & 13 & 18 \\
\hline Don't know & 1 & 1 & 1 & 0 & 0 \\
\hline Total & 100 & 100 & 100 & 100 & 100 \\
\hline \multicolumn{6}{|l|}{ Internet skills } \\
\hline Used the internet within the last 3 months & 92 & 80 & 80 & 91 & 90 \\
\hline Used the internet but not within last 3 months & 3 & 6 & 5 & 4 & 5 \\
\hline Never used the internet & 5 & 14 & 15 & 5 & 5 \\
\hline Total & 100 & 100 & 100 & 100 & 100 \\
\hline \multicolumn{6}{|l|}{ Skill level of current/last job } \\
\hline High skill & 13 & 16 & 15 & 20 & 11 \\
\hline Middle skill & 29 & 34 & 35 & 24 & 33 \\
\hline Low skill & 58 & 50 & 51 & 56 & 56 \\
\hline Total & 100 & 100 & 100 & 100 & 100 \\
\hline
\end{tabular}

Source: LFS

There is also a higher proportion of ESA than JSA claimants who have never used the internet (14 per cent compared to five per cent). Again those ESA claimants closer to the labour market are more similar to JSA claimants on this indicator.

As with JSA claimants, previous employment for ESA claimants is far more likely to have been in a low skill job (50 per cent) than the current job of those in employment (28 per cent). However, this is slightly less than the 58 per cent recorded for JSA claimants. ESA claimants who have been on this benefit for less than a year are more likely to have previously held a high skilled job (20 per cent) but this is still less than half the level seen amongst those in employment (45 per cent).

Table 5.9 indicates that having English as a second language is less prevalent amongst ESA claimants (6 per cent) than amongst either JSA claimants or the employed (both 10 per cent). However, ESOL ESA claimants compared to those in employment are more likely to have had language difficulties in education (27 per cent of ESOL ESA) and in finding or keeping a job (28 per cent of ESOL ESA). 
Table 5.9: English as a second language, ESA claimants aged 18-64, Great Britain, July September 2015

\begin{tabular}{|c|c|c|c|}
\hline & \multicolumn{3}{|c|}{ Per cent of } \\
\hline & Employed & $\begin{array}{c}\text { JSA } \\
\text { claimants }\end{array}$ & $\begin{array}{c}\text { ESA } \\
\text { claimants }\end{array}$ \\
\hline English as a second language (ESOL) & 10 & 10 & 6 \\
\hline \multicolumn{4}{|c|}{ Percentage of ESOL for whom language difficulties: } \\
\hline caused problems in education & 8 & 22 & 27 \\
\hline caused problems in finding or keeping a job & 14 & 36 & 28 \\
\hline
\end{tabular}

Source: LFS

The profile of ESA claimants shows that they have extensive barriers to work. Poor health and multiple health problems are the most significant of their issues, but they also have significant employability issues also including poor qualifications and long durations out-ofwork.

\section{Distribution of disadvantaged groups in Rotherham}

This report has focused on data for Rotherham as a whole relative to wider local and national benchmarks. In reality, residential segregation means that people who face multiple disadvantage in the workforce are often concentrated in particular neighbourhoods. Figure 5.2 maps the latest 2015 Index of Multiple Deprivation for LSOAs in Rotherham to give an indication of the areas and schools which may benefit from additional support for training, skills, careers advice and education initiatives. 
Figure 5.2: Index of Multiple Deprivation 2015, Rotherham

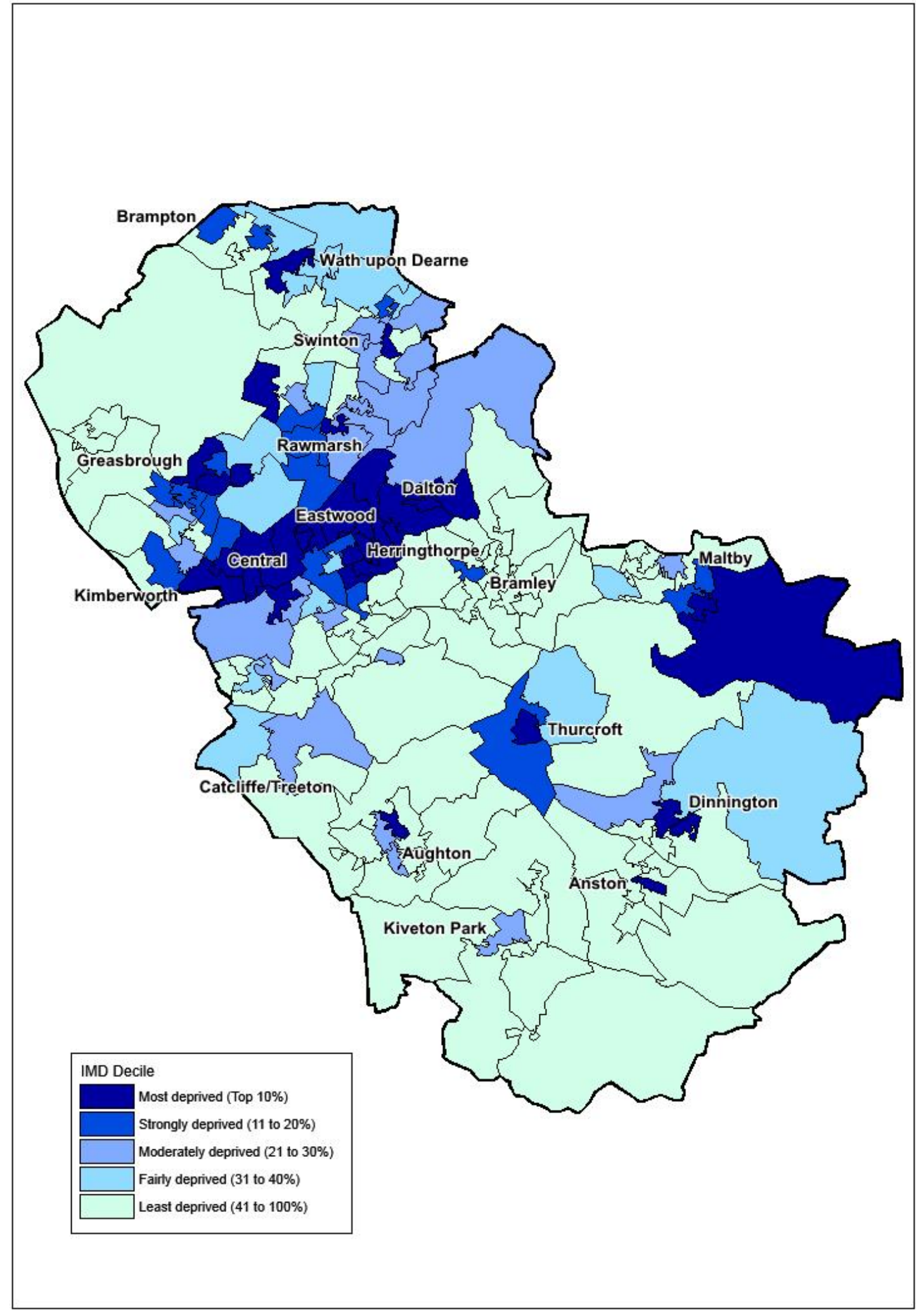

Source: CLG Index of Multiple Deprivation 2015 


\section{Young people and apprenticeships}

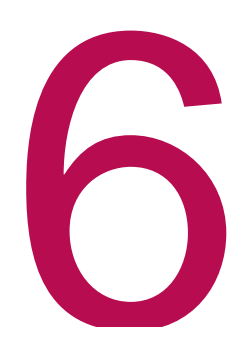

\section{Introduction}

Children of school age (4 -18 years old) are the primary target group for national education policy. This primarily focuses on reaching national specified educational attainment goals at key stages of a child's journey through school. At the end of year 11 this is assessed via SATs and primarily through GCSE exams when a child is 16 . At this point, post-16 education policy broadens out to cover both vocational skills and training as well as academic qualifications such as $A^{\prime}$ Levels. Children have to remain in compulsory training or education until they are 18.

Post-16 training or education may take the form of full-time education in a school or a Further Education college, by taking up an apprenticeship or traineeship ${ }^{16}$ or by spending 20 hours or more a week working or volunteering while in part-time education or training. Many young people continue with formal post- 18 education and training by entering University or taking up an apprenticeship.

There has been an increasing recognition by the Government that post- 16 training and skills options need to be reformed to provide a skilled workforce. The post-16 vocational and technical training system needs to meet the demands of businesses in a rapidly changing economy in-order to enhance productivity. This will contribute to improving social mobility, enhancing prosperity and security, and supporting young people to gain the skills that they need to enter the world of skilled work and move into fulfilling careers.

Since 2010, there have been a series of Government commissioned reviews and action plans to address these issues. These include the Wolf Report $(2011)^{17}$ which provides a review of vocational education, the Richard Review of Apprenticeships (2012), ${ }^{18}$ the Post-16 Skills Plan (2016), ${ }^{19}$ and most recently the T Level Action Plan 2018. ${ }^{20}$

\footnotetext{
${ }^{16}$ A traineeship is an education and training programme with work experience designed to help young people aged 16 to 24 to become 'work ready. It is aimed at young people who don't yet have the appropriate skills or experience to secure an apprenticeship or employment. Traineeships provide the essential work preparation training, English, maths and work experience.

${ }^{17}$ Wolf, A (2011) Review of Vocational Education: The Wolf Report . London: Department for Education.

${ }^{18}$ Richard, D. (2012) The Richard Review of Apprenticeships . London: School for Startups.

${ }^{19}$ Department of Business Innovations \& Skills and Department for Education (2016) Post-16 Skills Plan. London: Department for Education.

${ }^{20}$ Department for Education (2018) T Level Action Plan 2018. London: Department for Education.
} 
The T-Level Action Plan acknowledges that a world-class system of technical education is needed. This will help young people to better equip themselves to enter the world of work with the skills they need to get on in life. Technical education needs to support young people to gain the skills they need to move into fulfilling careers and progress through their working life. This system will not only help improve skill levels amongst young people but it will contribute towards improving social mobility and enhancing national productivity.

\section{Not in education, employment or training (NEETS)}

Local authorities have a duty to track and support young people in their education and training activities. They are required to identify those not participating in education, training or employment at the ages of 16-17. The data below shows the number and proportion of 16 and 17 year olds recorded as in education or training in Rotherham. It also estimates the proportion and number of 16- and 17-year-olds who are recorded as 'NEET' or whose activity is 'not known'.

Table 6.1:16-17 year olds in education and training in Rotherham, March 2018

\section{Rotherham England}

\begin{tabular}{lcr}
\hline Total number of $\mathbf{1 6}$ and $\mathbf{1 7}$ year olds & $\mathbf{6 , 0 4 0}$ & $\mathbf{1 , 1 3 6 , 3 2 0}$ \\
& & $\mathbf{9 2 . 3}$ \\
Total in education or training & 77.4 & 83.8 \\
Full-time education or training & 7.7 & 5.9 \\
Apprenticeship & 4.7 & 1.2 \\
Work based learning & 0.0 & 0.1 \\
Part-time education & 2.5 & 0.7 \\
Employment combined with study & 0.1 & 0.2 \\
Other & & \\
Percentage point change in year & 0.2 & -0.1 \\
(March to March) & & \\
Current activity not known & 2.0 & 2.8 \\
\hline
\end{tabular}

Source: Department for Education

Table 6.1 shows that there are just over 6,000 16 and 17 year olds in Rotherham and 92.3 per cent of them are in education or training. This is slightly above the national average for England of 92 per cent. Rotherham has also improved its position on this indicator over the year to March 2018; up by 0.2 percentage points compared to a fall nationally of 0.1 percentage points.

There are some notable differences in Rotherham compared to the national picture in terms of education and training destinations of 16 and 17 year olds. In Rotherham in 2018, 77.4 per cent are in full-time education or training compared to 83.8 per cent nationally. Conversely, 16 and 17 year olds are more likely to be in vocational training with 7.7 per cent in Apprenticeships, 4.7 per cent in work based learning and 2.5 per cent in employment combined with study. The comparative figures for England are lower at 5.9 per cent, 1.2 per cent and 0.7 per cent respectively. 
Table 6.2:16-17 year olds in education and training in Rotherham by ethnicity, March 2018

\begin{tabular}{ccc}
\hline & Rotherham & England \\
\hline Jun 2016 & 91.1 & 91.0 \\
Dec 2016 & 92.6 & 91.4 \\
Mar 2017 & 92.1 & 92.1 \\
June 2017 & 91.3 & 91.4 \\
Dec 2017 & 91.1 & 91.3 \\
Jan 2018 & 92.4 & 92.1 \\
Feb 2018 & 92.8 & 92.2 \\
Mar 2018 & 92.3 & 92.0 \\
\hline
\end{tabular}

Source: Department for Education

Table 6.2 shows that the proportion of 16 and 17 year olds recorded as being in full-time education and training has improved over time. In Rotherham, the increase of 1.2 percentage points between 2016 and 2018 was slightly greater than the 1 per cent improvement seen nationally.

Table 6.3:16-17 year olds in education and training in Rotherham by ethnicity, March 2018

\begin{tabular}{|c|c|c|c|c|}
\hline & \multicolumn{2}{|c|}{ Rotherham } & \multicolumn{2}{|c|}{ England } \\
\hline & $\begin{array}{l}\text { Number of } \\
16 / 17 \text { year } \\
\text { olds known } \\
\text { to LA }\end{array}$ & $\begin{array}{c}\text { Percentage of } \\
16-17 \text { year olds } \\
\text { participating in } \\
\text { education or } \\
\text { training }\end{array}$ & $\begin{array}{l}\text { Number of } \\
16 / 17 \text { year } \\
\text { olds known } \\
\text { to LA }\end{array}$ & $\begin{array}{c}\text { Percentage of } \\
16-17 \text { year olds } \\
\text { participating in } \\
\text { education or } \\
\text { training }\end{array}$ \\
\hline White & 5,280 & 91.9 & 771,210 & 91.2 \\
\hline Mixed race & 90 & 97.8 & 50,030 & 91.8 \\
\hline Black or black British & 60 & 94.8 & 51,850 & 94.9 \\
\hline Asian or Asian British & 370 & 97.3 & 99,950 & 96.4 \\
\hline Chinese & 10 & 100.0 & 3,880 & 97.8 \\
\hline Other & 40 & 95.5 & 17,800 & 93.6 \\
\hline All & 6,040 & 92.3 & $1,136,320$ & 92.0 \\
\hline
\end{tabular}

Source: Department for Education

Table 6.3 indicates that participation rates vary by ethnicity and the lowest rates are seen amongst white young people; 91.9 per cent in Rotherham compared to 91.2 per cent nationally. In Rotherham the highest rates are seen amongst mixed race 16-17 year olds (97.8) and Asians (97.3 per cent). With the exception of those classified as Black or Black British, the participation rates for all other ethnic groups in Rotherham are higher than for their national counterparts.

\section{Overview of the apprenticeship system}

The apprenticeship system in England has undergone a number of significant changes over the past 25 years. The Modern Apprenticeship scheme was introduced in 1994 and originally it was primarily aimed at 18-19 year olds. Apprenticeships offered people an opportunity to have paid work while working towards an NVQ level 3 qualification.

In 2004, the system underwent significant modifications. Level 2 apprenticeships were introduced and the upper age limit was removed to allow over 25 year olds to take up 
apprenticeships. Young Apprenticeships and Pre-Apprenticeships were also introduced for 14-16 year olds to provide work placements and an 'Entry to Employment' programme for young people not yet ready or able to enter an Apprenticeship. Higher level apprenticeships were introduced in 2006 and Degree Apprenticeships were introduced in 2015 (Table 6.4).

Table 6.4 Apprenticeship levels

\begin{tabular}{lll}
\hline & Level & Equivalent education level \\
\hline Intermediate & 2 & 5 GCSE passes \\
Advanced & 3 & 2 A Level passes \\
Higher & $4,5,6$ and 7 & Foundation degree or above \\
Degree & 6 and 7 & Bachelor's or master's degree \\
\hline
\end{tabular}

The Government commissioned the Leitch Review of Skills ${ }^{21}$ in 2004 which was completed in 2006. The aim was to identify the UK's "optimal skills mix in 2020 to maximise economic growth, productivity and social justice, and to consider the policy implications of achieving the level of change required". Recommendations included increasing the number of apprenticeships in the UK to 500,000 per year by 2020. The Apprenticeships, Skills, Children and Learning Act 2009 also introduced a duty to provide an apprenticeship place to all qualified 16 to 19 year olds who wanted one.

Further initiatives were introduced between 2010 and 2015 to increase the number of apprenticeships available: Train to Gain, the Plan for Growth, and the Skills System Reform Plan which included incentive payments to small employers.

In May 2017, a major change to the funding model was implemented with the introduction of the Apprenticeship Levy. All employers with a pay bill over $£ 3$ million per year are expected to pay the levy which is set at 0.5 per cent of the value of their wages bill, minus an allowance of $£ 15,000$ per financial year. Employers subject to the levy pay their apprenticeship training costs from the funds generated and the government tops up these funds by 10 per cent. Employers not subject to the levy generally pay 10 per cent of cost of training with the government contributing the remaining 90 per cent. ${ }^{22}$ For a full description of the impact of changes to the system on national trends in Apprenticeships see the House of Commons Library briefing on Apprenticeship Statistics. ${ }^{23}$

In 2017/18, there were 2,010 Apprenticeship starts in Rotherham. In the wake of the apprenticeship levy being introduced in May 2017, the numbers of apprenticeships began to fall substantially from the final quarter of 2016/17 (Table 6.5). Between 2015/16 and 2017/18, the rate of decline in Apprenticeships in Rotherham was even more rapid than that seen nationally; 1,190 fewer starts in Rotherham equivalent to a decrease of 39 per cent compared to England with a decline of 26 per cent.

The level of Apprenticeship taken has also changed in the wake of the funding changes.

\footnotetext{
${ }^{21}$ HMRC (2016) Leitch Review of Skills: Prosperity for all in the global economy - world class skills . London: TSO.

${ }^{22}$ A full description of the apprenticeship levy and the changes to the system over time is available in: House of Commons Library (2019) Apprenticeships and Skills Policy in England, Briefing Paper Number 03052 , January 2019.

${ }^{23}$ House of Commons Library (2019) Apprentice Statistics: England, Briefing Paper 06113, January 2019.
} 
Table 6.5: Apprenticeships in Rotherham by level, $2014 / 2015$ to $2017 / 2018$

\begin{tabular}{lrrrr}
\hline & $\mathbf{2 0 1 4 / 2 0 1 5}$ & $\mathbf{2 0 1 5 / 2 0 1 6}$ & $\mathbf{2 0 1 6 / 2 0 1 7}$ & $\mathbf{2 0 1 7 / 2 0 1 8}$ \\
\hline Rotherham & & & & \\
\hline Intermediate Apprenticeship & 1,990 & 2,040 & 1,700 & 850 \\
Advanced Apprenticeship & 1,100 & 1,090 & 1,180 & 900 \\
Higher Apprenticeship & 110 & 160 & 240 & 260 \\
Totals & $\mathbf{3 , 2 0 0}$ & $\mathbf{3 , 2 9 0}$ & $\mathbf{3 , 1 2 0}$ & $\mathbf{2 , 0 1 0}$ \\
& & & & \\
Intermediate Apprenticeship & 62.2 & 62.0 & 54.5 & 42.3 \\
Advanced Apprenticeship & 34.4 & 33.1 & 37.8 & 44.8 \\
Higher Apprenticeship & 3.4 & 4.9 & 7.7 & 12.9 \\
Totals & $\mathbf{1 0 0 . 0}$ & $\mathbf{1 0 0 . 0}$ & $\mathbf{1 0 0 . 0}$ & $\mathbf{1 0 0 . 0}$ \\
\hline England & & & & \\
\hline Intermediate Apprenticeship & 298,280 & 291,330 & 260,650 & 161,390 \\
Advanced Apprenticeship & 181,760 & 190,870 & 197,660 & 166,220 \\
Higher Apprenticeship & 19,770 & 27,160 & 36,570 & 48,150 \\
Totals & $\mathbf{4 9 9 , 8 9 0}$ & $\mathbf{5 0 9 , 3 6 0}$ & $\mathbf{4 9 4 , 8 8 0}$ & $\mathbf{3 7 5 , 7 6 0}$ \\
& & & & \\
Intermediate Apprenticeship & 59.7 & 57.2 & 52.7 & 43.0 \\
Advanced Apprenticeship & 36.4 & 37.5 & 39.9 & 44.2 \\
Higher Apprenticeship & 4.0 & 5.3 & 7.4 & 12.8 \\
Total & $\mathbf{1 0 0 . 0}$ & $\mathbf{1 0 0 . 0}$ & $\mathbf{1 0 0 . 0}$ & $\mathbf{1 0 0 . 0}$ \\
\hline Source: Department for Education & & & & \\
& & & & \\
\hline & & & & \\
\hline
\end{tabular}

Source: Department for Education

Until 2015/16 over 60 per cent of Apprenticeships in Rotherham were at an Intermediate level which was slightly higher than the rate seen in England. As the new system was introduced in 2016/17 the biggest decline in starts was at this level. Between 2015/16 and $2017 / 18$, the number of Intermediate starts fell more rapidly in Rotherham than nationally; by 58 per cent and 45 per cent respectively.

The profile of Apprenticeships has gradually been shifting towards proportionally more at an Advanced or Higher level. The number of Higher Apprenticeships increased by 63 per cent in Rotherham between 2015/16 and 2017/18 compared to 77 per cent in England. They now account for 12.9 per cent of all Apprenticeships and this is on par with the national picture.

Table 6.6 shows that there has been a decline in Apprenticeships starts for all age groups but this has been particularly stark amongst those aged over 25. Between 2015/16 and $2017 / 18$, the number of starts in Rotherham for those aged over 25 year olds fell by 43 per cent in compared to 31 per cent nationally. The over 25 age group now account for 38.8 per cent of all starts in Rotherham and a further third are aged under 19. Nationally, the number of starts for those aged between 19 and 24 fell to its lowest level since 2009/10. National figures also show that the number of women starting Apprenticeships in England has been higher than men for every year since 2010/11; in 2016/17, 54 per cent were by women and 46 per cent by men. 
Table 6.6: Apprenticeships in Rotherham by age, 2014/2015 to 2017/2018

\begin{tabular}{lrrrr}
\hline & $\mathbf{2 0 1 4 / 2 0 1 5}$ & $\mathbf{2 0 1 5 / 2 0 1 6}$ & $\mathbf{2 0 1 6 / 2 0 1 7}$ & $\mathbf{2 0 1 7 / 2 0 1 8}$ \\
\hline Rotherham & & & & \\
\hline Under 19 & 930 & 980 & 880 & 680 \\
$19-24$ & 980 & 940 & 800 & 550 \\
$25+$ & 1,290 & 1,380 & 1,450 & 780 \\
Totals & $\mathbf{3 , 2 0 0}$ & $\mathbf{3 , 3 0 0}$ & $\mathbf{3 , 1 3 0}$ & $\mathbf{2 , 0 1 0}$ \\
& & & & \\
Under 19 & 29.1 & 29.8 & 28.2 & 33.8 \\
19-24 & 30.6 & 28.6 & 25.6 & 27.4 \\
$25+$ & 40.3 & 41.9 & 46.5 & 38.8 \\
Totals & $\mathbf{1 0 0 . 0}$ & $\mathbf{1 0 0 . 3}$ & $\mathbf{1 0 0 . 3}$ & $\mathbf{1 0 0 . 0}$ \\
\hline England & & & & \\
\hline Under 19 & 125,850 & 131,420 & 122,750 & 106,570 \\
19-24 & 160,180 & 153,860 & 142,190 & 113,710 \\
$25+$ & 213,860 & 224,090 & 229,940 & 155,480 \\
Totals & $\mathbf{4 9 9 , 8 9 0}$ & $\mathbf{5 0 9 , 3 7 0}$ & $\mathbf{4 9 4 , 8 8 0}$ & $\mathbf{3 7 5 , 7 6 0}$ \\
& & & & \\
Under 19 & 25.2 & 25.8 & 24.8 & 28.4 \\
19-24 & 32.0 & 30.2 & 28.7 & 30.3 \\
25+ & 42.8 & 44.0 & 46.5 & 41.4 \\
Totals & $\mathbf{1 0 0 . 0}$ & $\mathbf{1 0 0 . 0}$ & $\mathbf{1 0 0 . 0}$ & $\mathbf{1 0 0 . 0}$ \\
\hline Souce: Dep & & & & \\
\hline
\end{tabular}

Source: Department for Education

The majority of apprenticeship starts were in the service sectors (Table 6.7). In Rotherham four subject areas account for 84.1 per cent of all starts in 2017/18: Health, Public Services and Care; Business, Administration and Law; Retail \& Commercial Enterprise; and Engineering and Manufacturing Technologies. This replicates the pattern seen nationally where 83.2 per cent of all starts being in these sectors.

Table 6.8 shows the decline in Apprenticeship starts for these main sectors. The 41 per cent decrease in Rotherham between 2015/16 and 2017/18 was more rapid than the 29 per cent nationally. The pattern was more mixed within the group: Health, Public Services and Care showed a slower rate of decline than nationally; Engineering and Manufacturing was similar to the national average; but Apprenticeships in Business, Administration and Law as well as Retail shrunk by a far greater extent than nationally. 


\begin{tabular}{lrrrr}
\hline & $2014 / 15$ & $2015 / 16$ & $2016 / 17$ & $2017 / 18$ \\
\hline Agriculture, Horticulture and Animal Care & 40 & 40 & 30 & 30 \\
Arts, Media and Publishing & 10 & 20 & 10 & 10 \\
Business, Administration and Law & 1,180 & 1,100 & 960 & 560 \\
Construction, Planning and the Built Environment & 120 & 170 & 130 & 150 \\
Education and Training & 60 & 60 & 70 & 40 \\
Engineering and Manufacturing Technologies & 550 & 620 & 560 & 440 \\
Health, Public Services and Care & 540 & 560 & 700 & 430 \\
Information and Communication Technology & 60 & 70 & 60 & 60 \\
Leisure, Travel and Tourism & 60 & 90 & 90 & 50 \\
Retail and Commercial Enterprise & 570 & 570 & 510 & 260 \\
Science and Mathematics & 0 & 0 & 0 & 0 \\
Totals & 3,200 & 3,290 & 3,120 & $\mathbf{2 . 0 1 0}$ \\
\hline Percentages & & & & \\
\hline Agriculture, Horticulture and Animal Care & 1.3 & 1.2 & 1.0 & 1.5 \\
Arts, Media and Publishing & 0.3 & 0.6 & 0.3 & 0.5 \\
Business, Administration and Law & 36.9 & 33.4 & 30.8 & 27.9 \\
Construction, Planning and the Built Environment & 3.8 & 5.2 & 4.2 & 7.5 \\
Education and Training & 1.9 & 1.8 & 2.2 & 2.0 \\
Engineering and Manufacturing Technologies & 17.2 & 18.8 & 17.9 & 21.9 \\
Health, Public Services and Care & 16.9 & 17.0 & 22.4 & 21.4 \\
Information and Communication Technology & 1.9 & 2.1 & 1.9 & 3.0 \\
Leisure, Travel and Tourism & 1.9 & 2.7 & 2.9 & 2.5 \\
Retail and Commercial Enterprise & 17.8 & 17.3 & 16.3 & 12.9 \\
Science and Mathematics & 0.0 & 0.0 & 0.0 & 0.0 \\
Totals & 100.0 & 100.0 & 100.0 & $\mathbf{1 0 0 . 0}$ \\
\hline Souce: D. & & & &
\end{tabular}

Source: Department for Education

Table 6.8: Change in Apprenticeships starts in Rotherham by main sectors, 2015/2016 to $2017 / 2018$

\begin{tabular}{|c|c|c|}
\hline & \multicolumn{2}{|c|}{$\begin{array}{l}\text { Percentage change } \\
2015 / 16 \text { to } 2017 / 18\end{array}$} \\
\hline & Rotherham & England \\
\hline Business, Administration and Law & -49 & -22 \\
\hline Engineering and Manufacturing Technologies & -29 & -25 \\
\hline Health, Public Services and Care & -23 & -33 \\
\hline Retail and Commercial Enterprise & -54 & -36 \\
\hline Main sectors & -41 & 29 \\
\hline All sectors & -39 & -26 \\
\hline
\end{tabular}

Source: Department for Education 


\section{Skills, qualifications and jobs}

\section{Introduction}

This chapter further develops our analysis of the Rotherham economy by examining a range of data related to basic skills, vocational qualifications, occupational structure, the sectoral composition of local workplaces and the employment they support, geographical variations in sectoral employment change, and the level of weekly earnings for those in full-time work.

\section{Educational attainment}

There is wide acceptance that high levels of literacy and numeracy are a prerequisite for successful participation and progression in the labour market. A key indicator of such levels is the extent to which school pupils at the end of their statutory period of education have achieved grades above a specified threshold in English and Mathematics. Up to the 2015/16 academic year the Department for Education set these as $A^{*}$ to $C$ grades at GCSE (or equivalent). With the change in grading system for 2016/17 this was changed to standard 9 to 4 grades. The two ranges are held to be commensurate with each other, and can therefore be compared over time.

Table 7.1 shows that the $2016 / 17$ figure for Rotherham is roughly in line with the national (English) and Combined Authority area averages. However, it is below achievement levels for the wider LEP area and the Yorkshire and Humber region. Over the four years for which statistics are available there has also been a small decrease in the percentage of pupils reaching the specified grades. This is in contrast to all other Boroughs in the Combined Authority, the LEP and regional and national averages. Indeed, from recording the highest achievement of the four South Yorkshire Boroughs in 2013/14 (and above sub-regional, regional and national averages), Rotherham most recent figure places it third behind Barnsley and Sheffield with respect to Key Stage 4 achievement.

While this relative deterioration undoubtedly provides grounds for concern, the reasons behind it are less clear. One factor may be the extent of demographic change affecting the Borough (see Chapter 2), especially the composition of its school age cohorts. For example, in-migration of young people whose first language is not English is likely to have an impact, suggesting that some measure of improvement from their starting point would be more appropriate than results of a one-off test. Unfortunately such an indicator does not exist at present. 
Table 7.1: Pupils achieving specified grades at Key Stage 4

\section{Number of pupils}

achieving grades
Percentage of pupils

Percentage

point

change

2013-2014 2016-2017 2013-2014 $2016-2017 \quad 2013-2017$

\begin{tabular}{|c|c|c|c|c|c|}
\hline Barnsley & 1,160 & 1,260 & 48.7 & 59.7 & 11.0 \\
\hline Sheffield & 3,050 & 3,030 & 56.2 & 59.5 & 3.3 \\
\hline Rotherham & 2,040 & 1,790 & 60.5 & 59.0 & -1.5 \\
\hline Doncaster & 1,780 & 1,750 & 52.8 & 58.4 & 5.6 \\
\hline Combined Authority & 8,030 & 7,820 & 55.2 & 59.2 & 4.0 \\
\hline Sheffield City Region LEP & $\mathrm{N} / \mathrm{A}$ & $N / A$ & 56.8 & 62.5 & 5.7 \\
\hline Yorkshire and Humber & 32,100 & 32,860 & 56.2 & 61.8 & 5.6 \\
\hline England & 343,310 & 347,300 & 55.5 & 59.1 & 3.6 \\
\hline
\end{tabular}

Source: Department for Education GCSE (Key Stage 4) Statistics

Note: Specified grades are $A^{*}-C$ in English and Mathematics at GCSE and equivalent 2013/14 to 2015/16; and standard 9-4 passes in English and Maths GCSEs 2016/17.

\section{Vocational qualifications}

Rotherham also compares rather unfavourably with regard to the extent to which working age residents have vocational qualifications. As Table 7.2 demonstrates, whilst the percentage holding National Vocational Qualifications (NVQ) at Level 2 and above witnessed a marginal increase between 2010 and 2017, in relative terms the Borough has fallen back to fourth place with respect to the other three Combined Authority areas. Moreover, there has even been a small decrease from the 67 per cent figure reached in 2014-2016, further widening the gap with sub-regional, regional and national averages.

Table 7.2: Working age population qualified at NVQ2 or above

\begin{tabular}{lrrrrr}
\hline & \multicolumn{2}{c}{$\begin{array}{c}\text { Number of adults aged } \\
\mathbf{1 6 - 6 4}\end{array}$} & $\begin{array}{c}\text { Percentage of working } \\
\text { age population }\end{array}$ & $\begin{array}{c}\text { Percentage } \\
\text { change }\end{array}$ \\
& $\mathbf{2 0 1 0 - 2 0 1 2}$ & $\mathbf{2 0 1 5 - 2 0 1 7}$ & $\mathbf{2 0 1 0 - 2 0 1 2}$ & $\mathbf{2 0 1 5 - 2 0 1 7}$ & $\mathbf{2 0 1 0 - 2 0 1 7}$ \\
\hline Sheffield & 250,400 & 278,600 & 69.4 & 74.9 & 11.3 \\
Barnsley & 89,700 & 105,300 & 61.3 & 69.0 & 17.4 \\
$\begin{array}{l}\text { Doncaster } \\
\text { Rotherham }\end{array}$ & 121,300 & 126,900 & 64.0 & 68.2 & 4.6 \\
Combined Authority & 100,700 & $\mathbf{1 0 4 , 1 0 0}$ & 62.2 & 65.6 & $\mathbf{3 . 4}$ \\
Sheffield City Region LEP & $\mathbf{5 6 2 , 0 0 0}$ & $\mathbf{6 1 4 , 9 0 0}$ & $\mathbf{6 5 . 5}$ & $\mathbf{7 0 . 7}$ & $\mathbf{9 . 4}$ \\
Yorkshire and Humber & 758,100 & 815,800 & 66.2 & 71.0 & 7.6 \\
& $2,224,300$ & $2,378,300$ & 66.3 & 70.7 & 6.9 \\
Great Britain & $\mathbf{2 7 , 1 8 9 , 9 0 0}$ & $\mathbf{2 9 , 4 7 0 , 7 0 0}$ & $\mathbf{6 9 . 5}$ & $\mathbf{7 4 . 2}$ & $\mathbf{8 . 4}$ \\
\hline Source: Annual Population Survey & & & & &
\end{tabular}

Again this relative worsening of Rotherham's position in terms of skills levels is a matter for concern, especially given the desire to attract better quality employment to the area on the one hand, and the extent to which residents rely on out-commuting to access employment 
on the other. The latter implies the ability to compete with candidates from other areas, a process in which possession of an appropriate level of skills (denoted by achievement of appropriate qualifications) is crucial. As with educational attainment the precise reasons for the divergent trajectory of Rotherham on this indicator are not fully understood, but it is likely that selective in- and out-migration will have played an important role.

\section{Businesses and workplaces}

Table 7.3 reveals that since the post-2008 financial crisis there has been a strong upsurge in local workplaces in the Borough, roughly in line with the rest of the sub-region, but somewhat greater than the wider region and Great Britain as a whole. The rate of increase in Rotherham between 2010 and 2017 has been second only to Doncaster within the Combined Authority, and has been higher than regional and national averages. However, in terms of representation per head of population the figure remains relatively low in comparison to benchmark areas, and the gap has remained much the same. Thus, the increase is likely to assist in boosting the local economy not least in fostering improved access to local employment opportunities for residents. However, this may not be on a sufficient scale to reduce the need for a substantial proportion to commute to work in places outside the Borough.

Table 7.3: Workplaces

\begin{tabular}{lccccc}
\hline & \multicolumn{2}{c}{ Number of local units } & \multicolumn{2}{c}{$\begin{array}{c}\text { Local units per 1,000 } \\
\text { population }\end{array}$} & $\begin{array}{c}\text { Percentage } \\
\text { change }\end{array}$ \\
& $\mathbf{2 0 1 0 - 2 0 1 2}$ & $\mathbf{2 0 1 5 - 2 0 1 7}$ & $\mathbf{2 0 1 0 - 2 0 1 2}$ & $\mathbf{2 0 1 5 - 2 0 1 7}$ & $\mathbf{2 0 1 0 - 2 0 1 7}$ \\
\hline Doncaster & 7,900 & 10,500 & 26 & 34 & 32.9 \\
Rotherham & 6,400 & 7,900 & 25 & 30 & $\mathbf{2 3 . 4}$ \\
$\begin{array}{l}\text { Barnsley } \\
\text { Sheffield }\end{array}$ & 5,900 & 7,000 & 26 & 29 & 18.6 \\
Combined Authority & 15,600 & 18,200 & 28 & 32 & 16.7 \\
Sheffield City Region & $\mathbf{3 5 , 9 0 0}$ & $\mathbf{4 3 , 6 0 0}$ & $\mathbf{2 7}$ & $\mathbf{3 1}$ & $\mathbf{2 1 . 4}$ \\
& 53,100 & 63,800 & 29 & 34 & 20.2 \\
Yorkshire and Humber & 176,700 & 206,800 & 33 & 38 & 17.0 \\
Great Britain & $\mathbf{2 , 3 8 3 , 6 0 0}$ & $\mathbf{2 , 8 4 3 , 0 0 0}$ & $\mathbf{3 9}$ & $\mathbf{4 5}$ & $\mathbf{1 9 . 3}$ \\
\hline
\end{tabular}

Source: UK Business Counts

In broad sectoral terms all types of activity have shared in this workplace growth, as Table 7.4 attests. However, some spheres have forged ahead much more quickly than others, with business services, construction and hospitality having increases of between a quarter and a half over the eight year period. Distribution and logistics has also seen workplace growth of almost a fifth, but this lower rate has meant that its overall share has declined very slightly. The lowest increases have been in primary activities (agriculture and quarrying), manufacturing and public services, all of which have consequently suffered a decrease in overall share. 
Table 7.4: Sectoral breakdown of local workplaces in Rotherham

\begin{tabular}{lrrrrr}
\hline & \multicolumn{2}{c}{ Number of local units } & \multicolumn{2}{c}{$\begin{array}{c}\text { Sectoral share (as } \\
\text { percentage of total) }\end{array}$} & $\begin{array}{c}\text { Percentage } \\
\text { change }\end{array}$ \\
& $\mathbf{2 0 1 0 - 2 0 1 2}$ & $\mathbf{2 0 1 6 - 2 0 1 8}$ & $\mathbf{2 0 1 0 - 2 0 1 2}$ & $\mathbf{2 0 1 6 - 2 0 1 8}$ & $\mathbf{2 0 1 0 - 2 0 1 8}$ \\
\hline Primary activities & 210 & 225 & 2.9 & 2.6 & 7.1 \\
Manufacturing & 605 & 635 & 8.5 & 7.2 & 5.0 \\
Construction & 900 & 1,215 & 12.6 & 13.8 & 35.0 \\
Distribution \& logistics & 1,905 & 2,265 & 26.6 & 25.8 & 18.9 \\
Hospitality \& catering & 425 & 545 & 5.9 & 6.2 & 28.2 \\
Business services & 1,560 & 2,305 & 21.8 & 26.2 & 47.8 \\
Public services & 1,545 & 1,595 & 21.6 & 18.2 & 3.2 \\
\hline Total & $\mathbf{7 , 1 5 0}$ & $\mathbf{8 , 7 8 5}$ & $\mathbf{1 0 0 . 0}$ & $\mathbf{1 0 0 . 0}$ & $\mathbf{2 2 . 9}$ \\
\hline
\end{tabular}

Source: UK Business Counts

\section{Workplace employment}

One expectation of the increase in the number of workplaces in Rotherham since 2010 might be a corresponding growth in employment. ${ }^{24}$ As Table 7.5 indicates this has indeed occurred, albeit at a much slower rate ( 6 per cent compared to 23 per cent). This implies that, while the Borough is continuing to make a gradual recovery from the post-2008 recession, the growth that it is experiencing is relatively lean, with employers able to operate with fewer staff. The trends have also varied by sector, with business services, hospitality and catering and construction all witnessing above average employment growth, and manufacturing industry managing to hold its own. The number of public sector workers also increased in line with the Borough average in spite of the continued policy of financial austerity. These new jobs were predominantly concentrated in health services.

Table 7.5: Sectoral breakdown of workplace employment, Rotherham, 2010-2017

\begin{tabular}{lrrrrr}
\hline & Number in employment & Sectoral share ( of total) & $\begin{array}{c}\text { Percentage } \\
\text { change }\end{array}$ \\
\cline { 2 - 5 } & $\mathbf{2 0 1 0 - 2 0 1 1}$ & $\mathbf{2 0 1 5 - 2 0 1 7}$ & $\mathbf{2 0 1 0 - 2 0 1 1}$ & $\mathbf{2 0 1 5 - 2 0 1 7}$ & $\mathbf{2 0 1 0 - 2 0 1 7}$ \\
\hline Primary activities & 2,550 & 2,050 & 2.6 & 2.0 & -19.6 \\
Manufacturing & 13,350 & 13,350 & 13.6 & 12.8 & 0.0 \\
Construction & 6,650 & 7,350 & 6.8 & 7.0 & 10.5 \\
Distribution \& logistics & 20,750 & 20,150 & 21.1 & 19.3 & -2.9 \\
Hospitality \& catering & 5,050 & 6,000 & 5.1 & 5.7 & 18.8 \\
Business services & 17,300 & 20,700 & 17.6 & 19.8 & 19.7 \\
Public services & 32,700 & 34,850 & 33.2 & 33.4 & 6.6 \\
\hline Total & $\mathbf{9 8 , 3 5 0}$ & $\mathbf{1 0 4 , 4 5 0}$ & $\mathbf{1 0 0 . 0}$ & $\mathbf{1 0 0 . 0}$ & $\mathbf{6 . 2}$ \\
\hline
\end{tabular}

Source: ONS Business Register Employment Survey

\footnotetext{
${ }^{24}$ The figures on workplace employment in this section are based on BRES data and differ in how the APS counts employment. BRES records returns from business on the number of employees and single traders. APS is a self-reported figure which also includes all self-employed.
} 
Table 7.6: Recent employment change by sector, Rotherham, 2015-2017

\begin{tabular}{lrrr}
\hline & \multicolumn{2}{c}{ Number in employment } & Change \\
& $\mathbf{2 0 1 5}$ & $\mathbf{2 0 1 7}$ & $\mathbf{2 0 1 5 - 2 0 1 7}$ \\
\hline Primary activities & 1,900 & 2,200 & 15.8 \\
Manufacturing & 14,000 & 14,000 & 0.0 \\
Construction & 7,000 & 8,000 & 14.3 \\
Distribution \& logistics & 19,750 & 20,750 & 5.1 \\
Hospitality \& catering & 6,000 & 6,000 & 0.0 \\
Business services & 20,450 & 20,700 & 1.2 \\
Public services & 34,500 & 31,500 & -8.7 \\
Total & $\mathbf{1 0 3 , 6 0 0}$ & $\mathbf{1 0 3 , 1 5 0}$ & $\mathbf{- 0 . 4}$ \\
\hline
\end{tabular}

Source: ONS Business Register Employment Survey

However, the figures on more recent employment trends suggest that the recovery may be faltering, with a marginal decrease in employment across the Borough between 2015 and 2017 (see Table 7.6). This is entirely due to the drop in jobs in public services, although business services, hospitality and manufacturing were all relatively static too. However, the numbers are single grossed-up estimates rather than three-year averages, and hence need to be treated with some caution. The relatively short time period also militates against drawing any definitive conclusions from these trends.

This pattern of recent change has varied considerably across the different parts of Rotherham Borough, with some areas experiencing employment growth and others job loss. Overall, a rough north/south divide emerges, albeit with some exceptions, with wards like Anston and Woodsetts, Dinnington and Rother Vale seeing increases of 5 per cent or more. Whilst places like the town centre, Silverwood, Swinton and Wingfield have all suffered losses (see Figure 4.1).

When broken down by sector the patterns of gain and loss become more varied. Thus, in terms of manufacturing Swinton and Wath in the north have shared employment growth with Brinsworth and Catcliffe, Holderness, Rother Vale and Wales in the south (see Figure 4.2). The biggest loser has been a cluster of eight wards in the centre of the Borough. For distribution and logistics and public sector services (Figures 4.3 and 4.4) the patterns are more disparate, although most of the big gains have again been in the south.

As far as public sector services are concerned, as Figure 4.5 not surprisingly indicates the majority of wards have undergone employment loss, particularly in the north of the Borough (with the sole exception of Rawmarsh). In contrast, four wards in the south (Anston and Woodsetts, Dinnington, Rother Vale and Wales) have experienced job gains in this sphere. 
Figure 7.1: Workplace Employment Change by Ward: All Sectors, 2015-2017

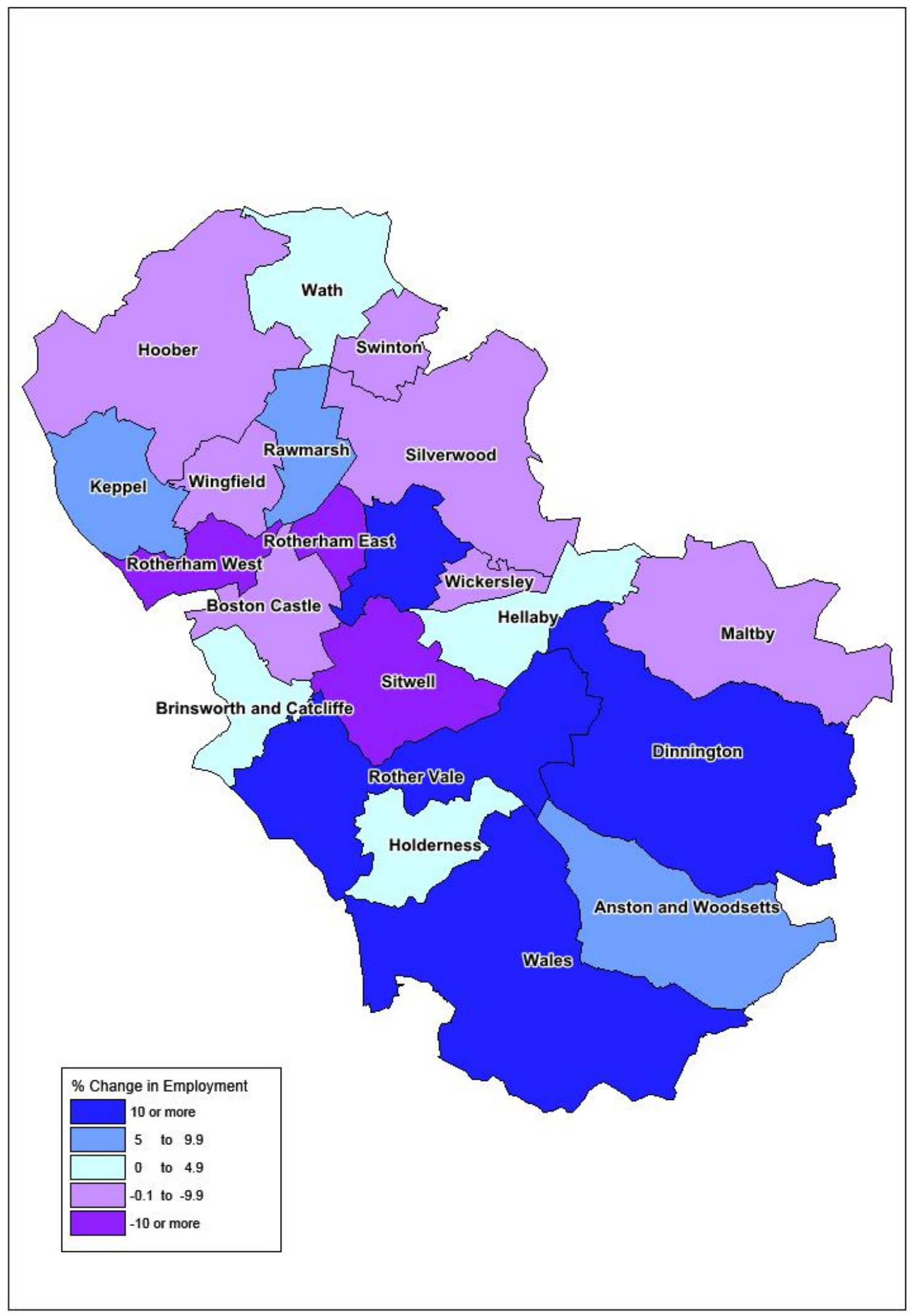

Source: ONS Business Register Employment Survey

Contains National Statistics data @ Crown copyright and database right [2017] 
Figure 7.2: Workplace Employment Change by Ward: Manufacturing, 2015-2017

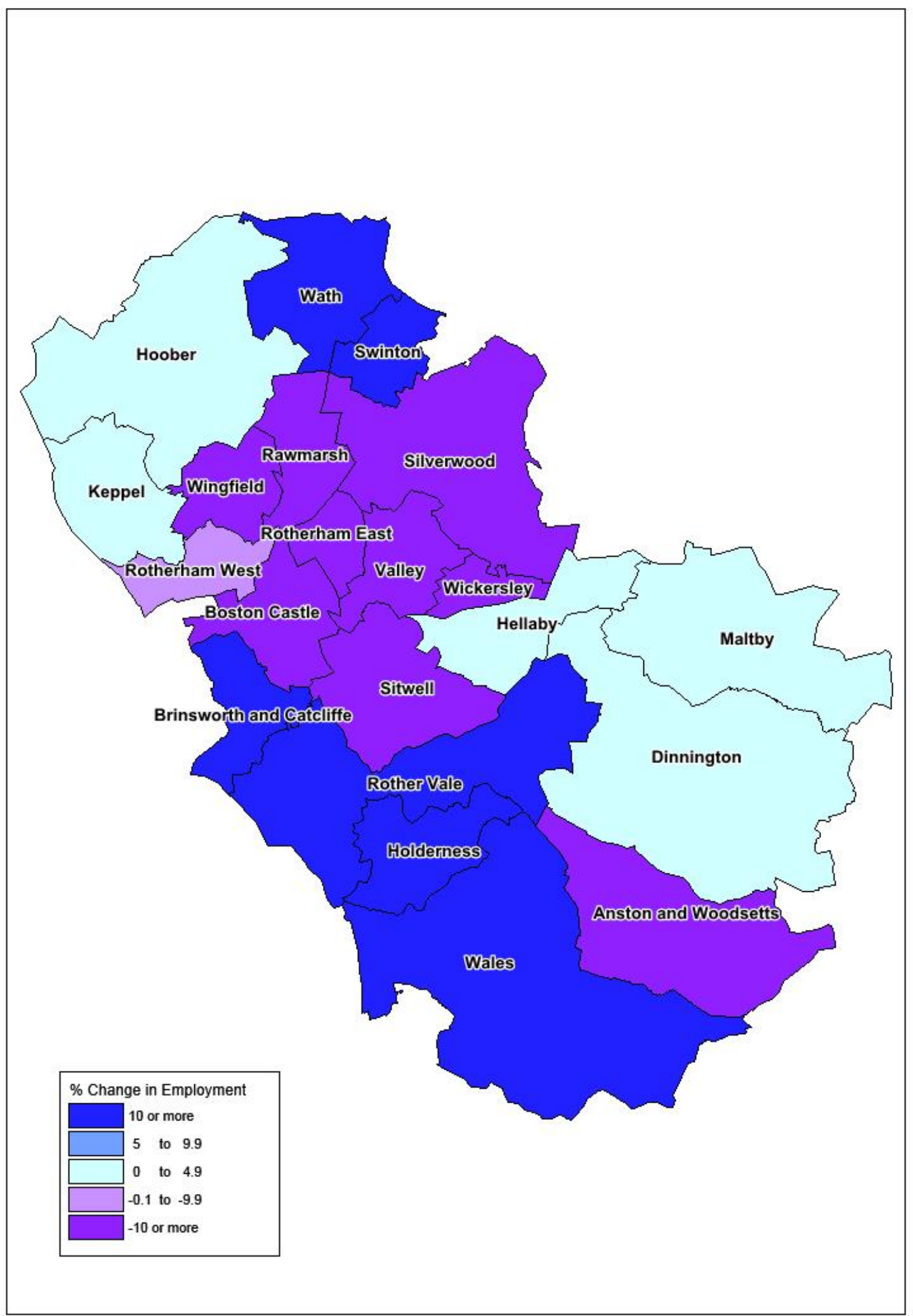

Source: ONS Business Register Employment Survey

Contains National Statistics data @ Crown copyright and database right [2017] 
Figure 7.3: Workplace Employment Change by Ward: Distribution and Logistics, 2015-2017

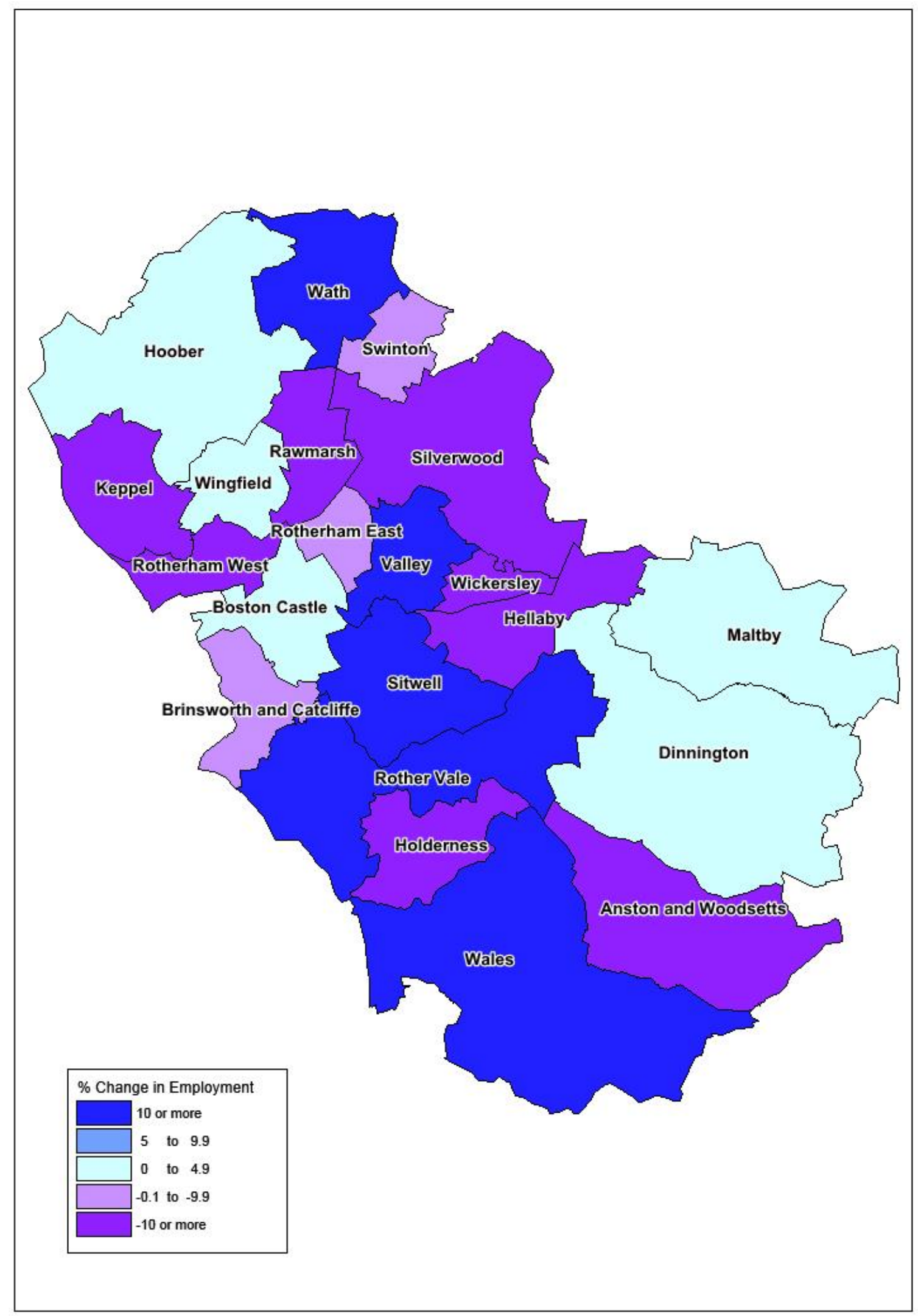

Source: ONS Business Register Employment Survey

Contains National Statistics data (C Crown copyright and database right [2017] 
Figure 7.4: Workplace Employment Change by Ward: Private Sector Services, 2015-2017

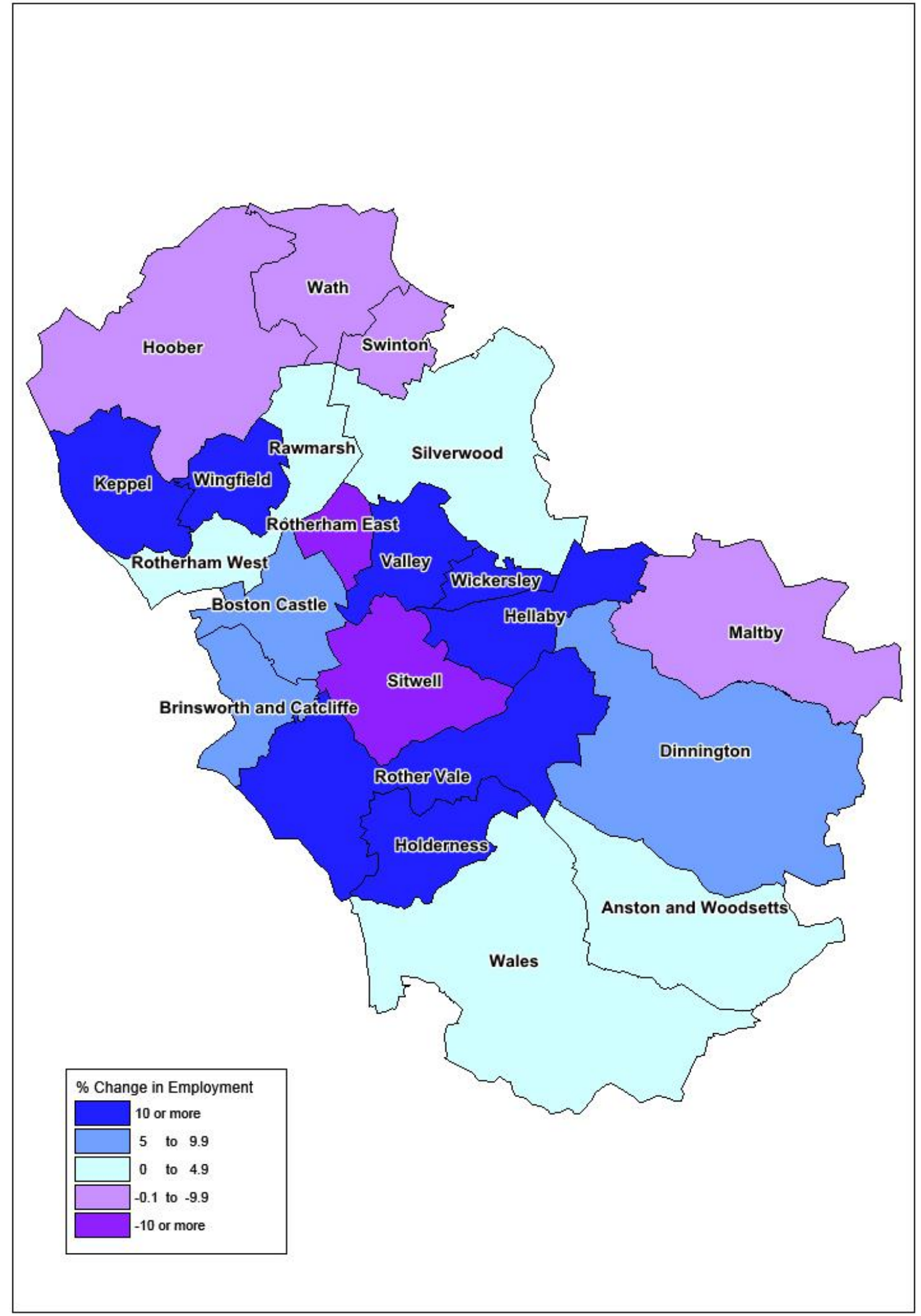

Source: ONS Business Register Employment Survey

Contains National Statistics data @ Crown copyright and database right [2017] 
Fig 7.5: Workplace Employment Change by Ward: Public Sector Services, 2015-2017

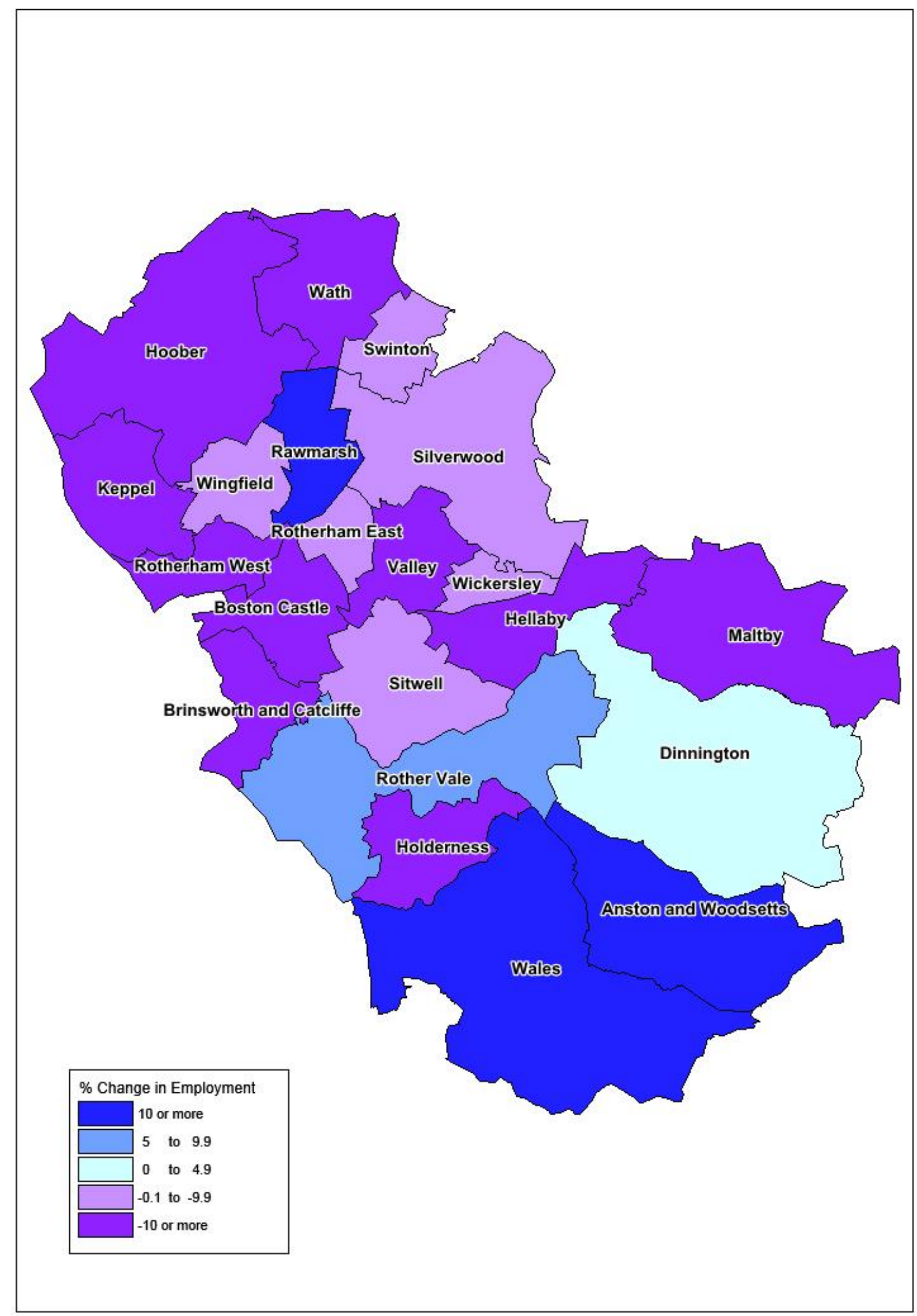

Source: ONS Business Register Employment Survey

Contains National Statistics data @ Crown copyright and database right [2017] 


\section{Employment quality}

Here employment quality is assessed according to two surrogate indicators, namely resident employment in higher level occupations at the top end, and workplace employment in low pay sectors at the bottom. 'Higher level' occupations are defined as Standard Occupational Classification (SOC) groups 1,2 and 3, covering managerial, professional and technical posts. 'Low pay' sectors are defined as those Standard Industrial Classification (SIC) categories covering retail, hospitality and catering, administrative and support service activities and residential care activities'.

Table 7.7 shows that in relative terms Rotherham's position on this indicator improved marginally between 2010 and 2018, with a 13 per cent increase in the number employed. This meant that the Borough moved from last to third position in the Combined Authority pecking order on this score. However, although the rate of increase was above that for the Sheffield City Region LEP area, and roughly in line with South Yorkshire and regional figures, it still lagged behind its neighbours Barnsley and Sheffield, as well as being below the national average. Thus, although the figure is moving in the right direction in relation to the ambitions for more Rotherham residents to move into better quality jobs, the gap with benchmark areas has only reduced very slightly, if at all.

Table 7.7: Resident employment in higher level occupations

\begin{tabular}{|c|c|c|c|c|c|}
\hline & \multicolumn{2}{|c|}{ Number in employment } & \multicolumn{2}{|c|}{ Employed workforce } & \multirow{2}{*}{$\begin{array}{c}\text { Percentage } \\
\text { change } \\
2010-2018\end{array}$} \\
\hline & 2010-2012 & $2016-2018$ & 2010-2012 & 2016-2018 & \\
\hline Barnsley & 33,100 & 38,900 & 33.5 & 34.9 & 18 \\
\hline Sheffield & 102,500 & 117,400 & 42.8 & 44.2 & 15 \\
\hline Rotherham & 35,400 & 40,000 & 32.2 & 34.3 & 13 \\
\hline Doncaster & 42,500 & 46,000 & 33.4 & 33.0 & 8 \\
\hline Combined Authority & 213,600 & 242,300 & 37.1 & 38.3 & 13 \\
\hline Sheffield City Region & 297,000 & 325,900 & 37.8 & 38.2 & 10 \\
\hline Yorkshire and Humber & 903,800 & $1,026,900$ & 38.4 & 40.3 & 14 \\
\hline Great Britain & $12,139,900$ & $13,952,700$ & 42.8 & 45.2 & 15 \\
\hline
\end{tabular}

Source: Annual Population Survey

Employment in 'low pay' sectors within the Rotherham area has increased by almost 10 per cent over the 2010-2012 to 2015-2017 period (see Table 7.8). This was in line with Combined Authority and national averages, but below the figures for the LEP and the wider region. It means that the contribution of these sectors to local employment remained at around a third of the total, and only just above regional and national figures. This placed it similarly in third place amongst the South Yorkshire Boroughs on this indicator. 


\begin{tabular}{|c|c|c|c|c|c|}
\hline & \multicolumn{2}{|c|}{ Number in employment } & \multicolumn{2}{|c|}{ Employed workforce } & \multirow{2}{*}{$\begin{array}{c}\text { Percentage } \\
\text { Change } \\
2010-2017\end{array}$} \\
\hline & 2010-2012 & 2015-2017 & $2010-2012$ & 2015-2017 & \\
\hline Sheffield & 75,500 & 82,800 & 30.8 & 31.9 & 9.7 \\
\hline Barnsley & 22,100 & 25,600 & 30.3 & 32.4 & 15.8 \\
\hline Rotherham & 32,200 & 35,300 & 33.2 & 34.1 & 9.6 \\
\hline Doncaster & 38,800 & 42,800 & 34.5 & 34.5 & 10.3 \\
\hline Combined Authority & 169,700 & 186,300 & 32.1 & 32.9 & 9.8 \\
\hline Sheffield City Region & 228,000 & 252,700 & 32.4 & 34.0 & 10.8 \\
\hline Yorkshire and Humber & 735,700 & 823,700 & 33.3 & 33.8 & 12.0 \\
\hline Great Britain & $9,261,000$ & $10,178,300$ & 33.3 & 33.8 & 9.9 \\
\hline
\end{tabular}

Source: Business Register Employee Survey

\section{Earnings}

Two measures are used to assess patterns and trends in earnings from paid work. The first is the median gross weekly figure (i.e., before deductions for tax and National Insurance). This indicates the numerical mid-point of the distribution, and is thus not affected by any extreme outlier values at the top or bottom of the range. The second measure is the maximum amount earned by those in the lowest paid quintile (or 20 per cent) of those covered by the survey. This provides an indication of the disparity between those with the worst remuneration and those in the middle. Both measures relate to full-time workers, selected to give an idea of the weekly income the main or sole breadwinner of a household might expect to receive.

Table 7.9: Median gross weekly earnings for full-time workers

\begin{tabular}{|c|c|c|c|c|c|}
\hline & \multicolumn{2}{|c|}{ Median earnings $(\mathfrak{E})$} & \multicolumn{2}{|c|}{ Gap to $G B$ average $(£)$} & \multirow{2}{*}{$\begin{array}{c}\text { Percentage } \\
\text { change } \\
2010-2018\end{array}$} \\
\hline & 2010-2012 & 2016-2018 & 2010-2012 & 2016-2018 & \\
\hline Sheffield & 380 & 419 & 25 & 31 & 10.3 \\
\hline Rotherham & 355 & 396 & 50 & 54 & 11.5 \\
\hline Doncaster & 363 & 391 & 42 & 59 & 7.7 \\
\hline Barnsley & 366 & 388 & 39 & 62 & 6.0 \\
\hline Combined Authority & 370 & 406 & 35 & 44 & 9.7 \\
\hline Sheffield City Region & 368 & 400 & 37 & 50 & 8.7 \\
\hline Yorkshire and Humber & 374 & 411 & 31 & 39 & 9.9 \\
\hline Great Britain & 405 & 450 & -- & -- & 11.1 \\
\hline
\end{tabular}

Source: ONS Annual Survey of Hours and Earnings 
Table 7.9 illustrates that between 2010 and 2018 Rotherham fared better than the other Combined Authority areas and its benchmarks in terms of median earnings, with the highest rate of increase. This moved it from last to second place in the South Yorkshire list, although it still fell some way behind the LEP, regional and national averages. Indeed, the disparity with the Great Britain figure actually increased, as was the case for all four Boroughs, albeit on a relatively marginal scale. In spite of the improvement, therefore, and in common with its neighbours Barnsley and Doncaster, Rotherham remains what can be considered a 'low pay' labour market.

In terms of the earnings levels of the lowest paid 20 per cent, Rotherham started and finished at the foot of the South Yorkshire list, in spite of a slightly stronger increase between 2010 and 2018 compared to the other three Boroughs (see Table 7.10). That said, its growth fell a little short of the increase recorded across the wider region, as well as that for Great Britain. This meant that the gap with the national average went up from $£ 20$ to £24, further underlining the Borough's position as a 'low pay' area.

Table 7.10: Gross weekly earnings for full-time workers in lowest income group

\begin{tabular}{|c|c|c|c|c|c|}
\hline & \multicolumn{2}{|c|}{ Weekly earnings (£) } & \multicolumn{2}{|c|}{ Gap to GB average (£) } & \multirow{2}{*}{$\begin{array}{l}\text { Percentage } \\
\text { change } \\
2010-2018\end{array}$} \\
\hline & 2010-2012 & 2016-2018 & 2010-2012 & 2016-2018 & \\
\hline Barnsley & 200 & 227 & 8 & 11 & 13.5 \\
\hline Sheffield & 194 & 217 & 14 & 21 & 11.9 \\
\hline Doncaster & 191 & 217 & 17 & 21 & 13.6 \\
\hline Rotherham & 188 & 214 & 20 & 24 & 13.8 \\
\hline Combined Authority & 193 & 218 & 15 & 20 & 13.0 \\
\hline Sheffield City Region LEP & 197 & 217 & 11 & 21 & 10.2 \\
\hline Yorkshire and Humber & 194 & 223 & 14 & 15 & 14.9 \\
\hline Great Britain & 208 & 238 & -- & -- & 14.4 \\
\hline
\end{tabular}

Source: ONS Annual Survey of Hours and Earnings

Table 7.11: Ratio between median and lowest paid gross weekly earnings

\begin{tabular}{lrr}
\hline & \multicolumn{2}{c}{ Median/Low pay ratio } \\
& 2010-2012 & 2016-2018 \\
\hline Sheffield & 1.96 & 1.93 \\
Rotherham & $\mathbf{1 . 8 9}$ & $\mathbf{1 . 8 5}$ \\
Doncaster & 1.90 & 1.80 \\
Barnsley & 1.83 & 1.71 \\
Combined Authority & $\mathbf{1 . 9 2}$ & $\mathbf{1 . 8 6}$ \\
Sheffield City Region LEP & 1.87 & 1.84 \\
Yorkshire and Humber & 1.93 & 1.84 \\
Great Britain & $\mathbf{1 . 9 5}$ & $\mathbf{1 . 8 9}$ \\
\hline
\end{tabular}

Source: ONS Annual Survey of Hours and Earnings 
At the same time, there has been a marginal improvement in the pay received by the lowest paid relative to those in the middle, with the ratio between median and lowest earnings decreasing in all areas (see Table 4.11). However, this is likely to stem more from general wage stagnation for those on rates above the National Minimum Wage, rather than any step change away from low paid (and often precarious) work. 


\section{Summary}

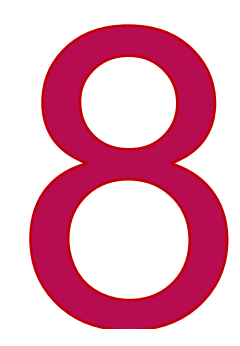

The previous chapters have shown that patterns of labour market participation vary substantially across sub-groups of the population in Rotherham. Taking a straightforward overview of the resident working age population as a whole hides the complexities of the supply and demand for labour in the area. Not least the analysis indicates that labour markets operate at higher spatial levels than local authority boundaries. A third of jobs in Rotherham are filled by workers from outside the area and only just over a half of residents in employment have a workplace within the district. Rotherham subsequently exports workers to job opportunities not just in the wider Combined Authority or City Region but also further afield.

The analysis shows that Rotherham lags behind national trends on many of the indicators economic activity rates, employment rates, unemployment rates, incapacity benefits rates and wages. That said, many of the indicators are moving in the right direction and in many cases have narrowed the gap between the local and the national picture. To some extent, the continued lower employment and participation rates observed in Rotherham are to be expected as the national average is buoyed by the inclusion of the much of Southern England which has been at or near levels of full employment for a considerable time. The dominance of high GVA industries such as Finance also skews the national benchmark towards higher skilled jobs and wages.

The analysis of sub-groups shows that whilst lower rates of labour market participation exist amongst ethnic minority groups these are not substantively different than seen amongst comparable groups elsewhere. Where there are differences by ethnicity and gender it is men not women of Pakistani or Bangladeshi heritage that have notably different patterns of labour market participation than those seen nationally. This does not translate into lower employment rates for these men which are similar to the national picture. However, it does switch the balance towards a lower proportion of men of Pakistani or Bangladeshi heritage who are actively seeking work and defined as ILO unemployed, and how many of them are not seeing work and are therefore defined as economically inactive. The men in this latter group are also more likely to say they want a job than this group nationally.

There is a more mixed picture on skills and qualifications amongst residents in Rotherham. The proportion of pupils achieving an $A^{*}-C$ in English and Mathematics at GCSE is on par with the national average. However, whilst improvements were made in the wider local and national benchmark areas, Rotherham deteriorated slightly over time. Only two thirds of working age residents in Rotherham are qualified at NVQ2 level or above. Rotherham continues to lag behind the other districts in the Combined Authority on this indicator and compares poorly with the national benchmark which stands at three quarters of the working 
age population. The improvement on this indicator for Rotherham over time was also far less than that seen in the Combined Authority. The change in the funding system for Apprenticeships has also had a negative impact on the number of people taking up training opportunities. Whilst this is a national trend, the impact in Rotherham and especially amongst over 25 year olds has been starker.

Equipping the local population with appropriate higher level skills and qualifications therefore enables residents to not only compete for the job opportunities on their doorstep but also those further afield. This will enhance the local economy and support growth in the wider Sheffield City Region. Improving the skills base of the workforce will not only benefit local residents but it will also support local businesses to expand. Enhanced pay levels that residents will be able to command in higher skilled jobs will also translate into higher disposable incomes which in turn will strengthen the local economy. 


\section{Appendix 1: Data sources}

Annual Population Survey - NOMIS and UK Data Service

Annual Survey of Earnings and Hours - NOMIS

Apprenticeship data - Department of Education

Business Register Employee Survey - NOMIS

2011 Census - NOMIS

DWP Working Age Benefits data - NOMIS

Labour Force Survey - UK Data Service

Mid-Year Population Estimates - NOMIS

Migration Indicators Suite - ONS

NEETs data - Department of Education

NOMIS - ONS Official Labour Market Statistics

Stat-Xplore - DWP benefits data

UK Data Service:

Office for National Statistics, Social Survey Division. (2018). Annual Population Survey 2004-17: Secure Access. [data collection]. 13 Edition. UK Data Service: SN 6721, http://doi.org/10.5255/UKDA-SN-6721-12

Northern Ireland Statistics and Research Agency, Central Survey Unit, Office for National Statistics, Social Survey Division. (2017). Quarterly Labour Force Survey, July September, 2015. [data collection]. 5th Edition. UK Data Service. SN: 7842, http://doi.org/10.5255/UKDA-SN-7842-5

Universal Credit Data - Stat-Xplore 


\section{Sheffield Hallam University}

Labour Market Participation, Skills, and Employment in Rotherham

BEATTY, Christina <http://orcid.org/0000-0003-0943-9979>, GORE, Anthony and LEATHER, David

Available from the Sheffield Hallam University Research Archive (SHURA) at:

http://shura.shu.ac.uk/24566/

\section{Copyright and re-use policy}

Please visit http://shura.shu.ac.uk/24566/ and http://shura.shu.ac.uk/information.html for further details about copyright and re-use permissions. 